INTER NATIONAL MONETARY FUND
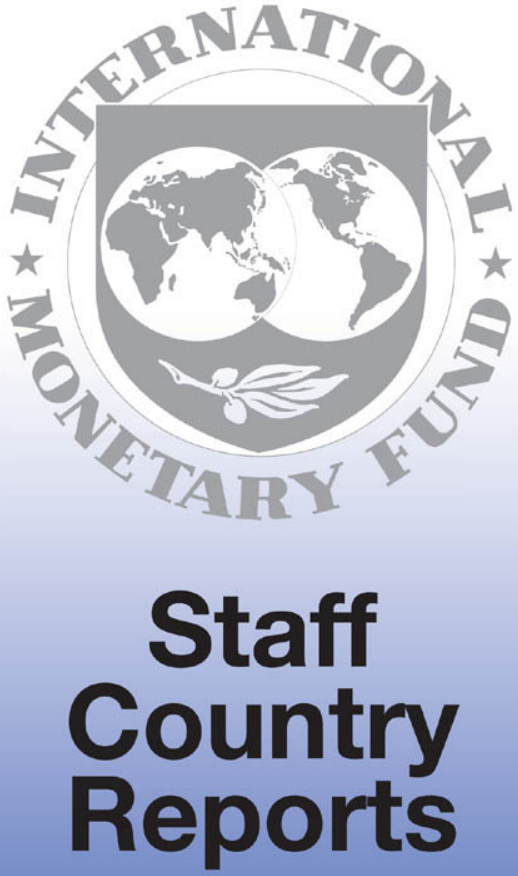


\section{Republic of Armenia: Poverty Reduction Strategy Paper Progress Report}

Poverty Reduction Strategy Annual Progress Reports (PRSPs) are prepared by member countries in broad consultation with stakeholders and development partners, including the staffs of the World Bank and the IMF. Updated every three years with annual progress reports, they describe the country's macroeconomic, structural, and social policies in support of growth and poverty reduction, as well as associated external financing needs and major sources of financing. This country document for the Republic of Armenia is being made available on the IMF website by agreement with the member country as a service to users of the IMF website.

To assist the IMF in evaluating the publication policy, reader comments are invited and may be sent by e-mail to publicationpolicy@imf.org.

Copies of this report are available to the public from

International Monetary Fund $\bullet$ Publication Services

$70019^{\text {th }}$ Street, N.W. • Washington, D.C. 20431

Telephone: (202) 623-7430 • Telefax: (202) 623-7201

E-mail: publications@imf.org • Internet: http://www.imf.org

Price: $\$ 15.00$ a copy

\section{International Monetary Fund Washington, D.C.}


This page intentionally left blank 


\section{Government of the \\ Republic of Armenia}

\section{Poverty Reduction Strategy Paper \\ Progress Report \\ (2004-2005 First Term)}

YEREVAN 2006 
This page intentionally left blank 
Introduction

PRSP Objectives of Poverty and Inequality Reduction and 2001-2004 Main

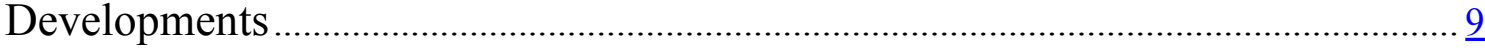

General Picture of Poverty and Inequality.................................................................. 9

Poverty in Urban and Rural Areas and by Marzes .....................................................11

2003-2004 Poverty Descriptions of Socially Vulnerable Groups …………………....13

Poverty reduction strategy................................................................................ 14

Sustainable Economic Growth and Institutional Reforms.........................................14

2004 Major Economic Developments and 2005 First Term Development Trends .......... 14

Business Environment.........................................................................................20

System of Public Administration ..........................................................................

Tax and Customs Administration.......................................................................... 24

Poverty Reduction Targeted Policy in Individual Spheres.......................................... 25

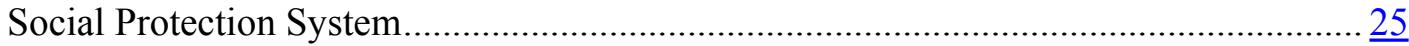

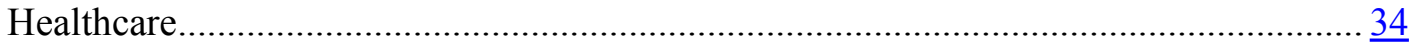

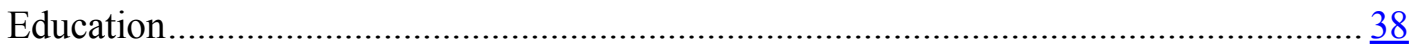

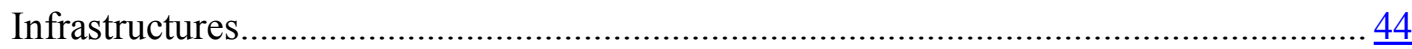

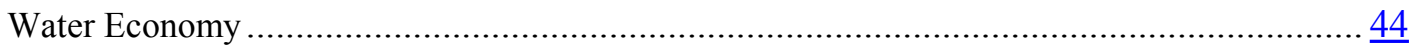

Road Construction ........................................................................................

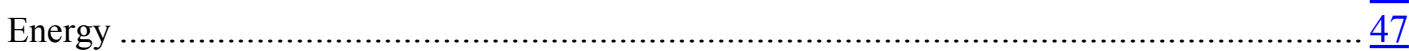

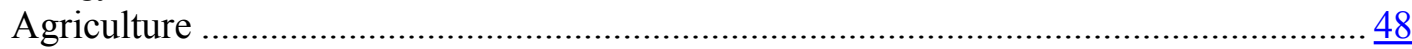

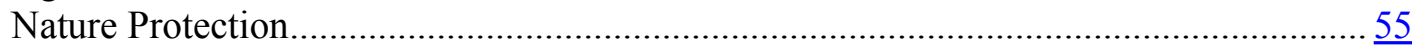

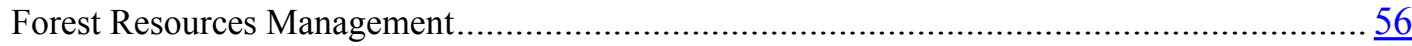

Rehabilitation of Lake Sevan Ecosystem ………………………………………….. $\frac{56}{57}$

Harmful Industrial Waste ........................................................................................

Rehabilitation and Development of Physical Infrastructures............................................ $\frac{57}{57}$

Strengthening the Legal Framework Regulating Nature Protection and Nature..................... 57

Budgetary Program …………………………………………………………... 59

Poverty Reduction Strategy and Medium-Term Expenditure Framework Program. $\underline{62}$ The Measures Undertaken for Ensuring Public Participation in the PRSP Implementation Process ................................................................................................ 65

PRSP and the Donor Community Support Coordination.......................................... Development and Introduction Process of the PRSP Monitoring and Evaluation

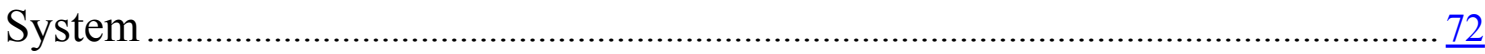

Possible Changes and Clarifications of the PRSP Indicators ................................... 75 
TABLE 1. 1999-2004 SELECTED POVERTY INDICATORS …........................................ $\underline{9}$

TABLE 2. 1999-2004 STRUCTURE OF HOUSEHOLD CASH INCOME …..................... 10

TABLE 3. 1999-2004 URBAN AND RURAL POVERTY * ........................................... $\frac{12}{12}$

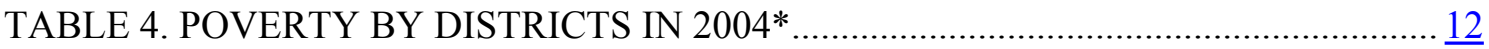

TABLE 5. 2003-2004 POVERTY OF THE SOCIALLY VULNERABLE GROUPS* ......... 14

TABLE 6. SELECTED ECONOMIC INDICATORS. ACTUAL VS PROGRAMMED ....... $\underline{16}$

TABLE 8. CONSOLIDATED BUDGET EXPENDITURES ON SOCIAL PROTECTION

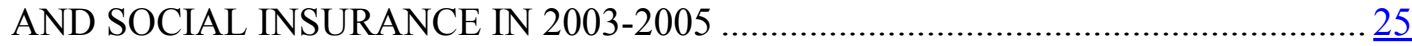

TABLE 9. EXPENDITURES ON FAMILY BENEFITS IN 2003-2005 ............................ $\underline{26}$

TABLE 10. ALTERATION OF POVERTY LEVEL WITHOUT PAYMENT OF SOCIAL ASSISTANCE AND SOCIAL TRANSFERS ……................................................. 27

TABLE 11. CONSOLIDATED BUDGET EXPENDITURES ON PENSIONS IN 2003-2005

TABLE $12 \cdot$ STATE BUDGET EXPENDITURES IN HEALTHCARE IN 2003-2005

TABLE 13. CONSOLIDATED BUDGET EXPENDITURE FOR EDUCATION OVER

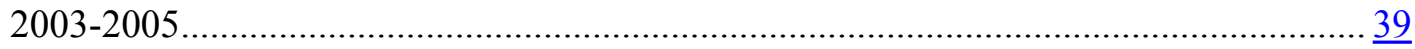

TABLE 14. AFFORDABILITY OF DRINKING WATER …....................................... 45

TABLE 13: DYNAMICS OF GROSS AGRICULTURAL PRODUCT OVER 2001 - 2004

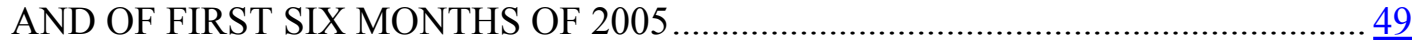

TABLE 16. 2002-2005 CONSOLIDATED BUDGET FRAMEWORK (ON AN ACCRUED

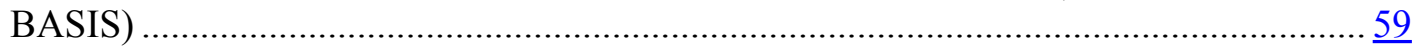

TABLE 17. BUDGETARY FRAMEWORK: 2005-2008 PRSP AND 2006-2008

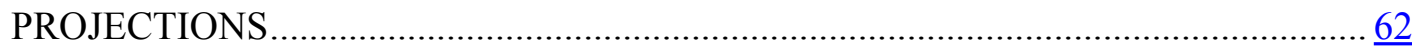

TABLE 18. STATE BUDGET EXPENDITURES UNDER PRSP AND 2006-2008MTEF.. $\underline{64}$

TABLE 19. SUMMARIZED STATISTICAL DATA OF THE PRSP MONITORING INDICATORS ..................................................................................................... 73

TABLE 20. EVALUATION OF THE 2004 PRSP IMPLEMENTATION PROGRESS ACCORDING TO THE METHODOLOGY ENVISAGED BY THE CONCEPT ON THE PRSP MONITORING INDICATORS' SYSTEM. $\underline{73}$

TABLE 21. FORMAT OF SUBMITTING DATA ON THE PRSP ACTIVITIES IMPLEMENTATION

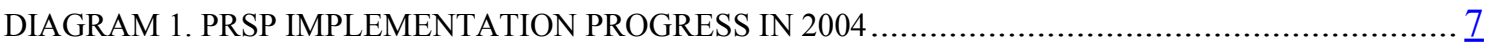

DIAGRAM 2. GDOP STRUCTURE BY MAJOR SECTORS (IN PERCENT) …................................. $\frac{16}{7}$

DIAGRAM 1.2004-2015 UPDATED PROJECTION OF THE POVERTY RATE ..................................... $\underline{78}$

ANNEX 1. PROGRESS IN POVERTY REDUCTION: SUMMARY INDICATORS …....... $\underline{79}$ ANNEX 2. BREAKDOWN OF GROSS DOMESTIC PRODUCT BY MAIN SECTOR ..... $\underline{80}$ SOURCE: NATIONAL STATISTICAL SERVICE OF THE REPUBLIC OF ARMENIA AND PRSP PROJECTIONS.ANNEX 3. USE OF GROSS DOMESTIC PRODUCT $\ldots \underline{80}$ ANNEX 3. USE OF GROSS DOMESTIC PRODUCT …................................................. $\underline{81}$ ANNEX 4. CONSOLIDATED BUDGET OPERATIONS (ON A COMMITMENT BASIS)

ANNEX 5. CONSOLIDATED BUDGET OPERATIONS: EXTERNAL FINANCING REQUIREMENTS ……............................................................................ $\frac{83}{\mathrm{~A}}$ ANNEX 6. CONSOLIDATED BUDGET EXPENDITURE BY MAIN FUNCTIONS (ON A COMMITMENT BASIS) $\underline{84}$

SOURCE: MINISTRY OF FINANCE AND ECONOMY OF THE REPUBLIC OF ARMENIA, STATE SOCIAL INSURANCE FUND OF THE REPUBLIC OF 
ARMENIA, AND PRSP PROJECTIONS.ANNEX 7. CONSOLIDATED BUDGET

SOCIAL EXPENDITURES (ON A COMMITMENT BASIS)

ANNEX 7. CONSOLIDATED BUDGET SOCIAL EXPENDITURES (ON A COMMITMENT BASIS)

ANNEX 8. ARMENIA: BALANCE OF PAYMENTS

ANNEX 9. PRSP MONITORING INDICATORS.

ANNEX 10 PRSP REVISION PROPOSALS FROM NGO SECTOR $\frac{95}{98}$

ANNEX 11. POVERTY ASSESSMENT NEW METODOLOGY 


\section{Introduction}

1. In August 2003, the Government adopted the Poverty Reduction Strategy Paper (PRSP) and initiated its implementation. After the approval of the PRSP in January 2004, the government developed an action plan aimed at ensuring the execution of the PRSP. The Government has also established a mechanism for the provision of quarterly reports by the state governance bodies on the progress of the implemented action plan. The PRSP was developed in close cooperation with all the stakeholders (state governance bodies, private sector, civil society, and donor community), and presently the government takes measures to ensure adequate participatory process in the PRSP implementation.

2. This progress report presents the analysis of the work carried out by the Government during 2004 and the first term of 2005 for the PRSP implementation ${ }^{1}$.

3. The first part of the report includes a comparative analysis of the PRSP objectives and actual results in terms of poverty and inequality, focusing on the problems in the regions and of the vulnerable social groups.

4. The second part of the report deals with the macroeconomic framework and institutional reforms, as well as the policies implemented in various sectors - indicating the achievements and identifying the outstanding problems in these sectors. In particular, the report includes analysis of other steps and measures of the government policy in the areas of education, health, social protection, as well as the analysis of the developments and the progress in these areas.

5. The report pays a special attention to the issues related to the state finances, focusing on the medium-term government policies.

6. The successful implementation of the PRSP is largely conditioned by involvement and active participation of the civil society, private sector and donor community in the process. The next two chapters of the report describe the progress achieved so far in these areas.

7. Within the context of the program assessment results and ensuring the efficiency of further revisions, a pivotal role is given to the development and implementation of the system of the program monitoring. During the last year, the Government took several steps in this direction, and the results are presented in this report.

8. The first years of the PRSP implementation confirm the Government commitment in pursuing the decisive policies in the PRSP priority areas, but at the same time they identify some problems for the solution of which the Government should take new efforts.

\footnotetext{
${ }^{1}$ Works carried out during 2005 are mainly presented within the government expenditure policy documents.
} 


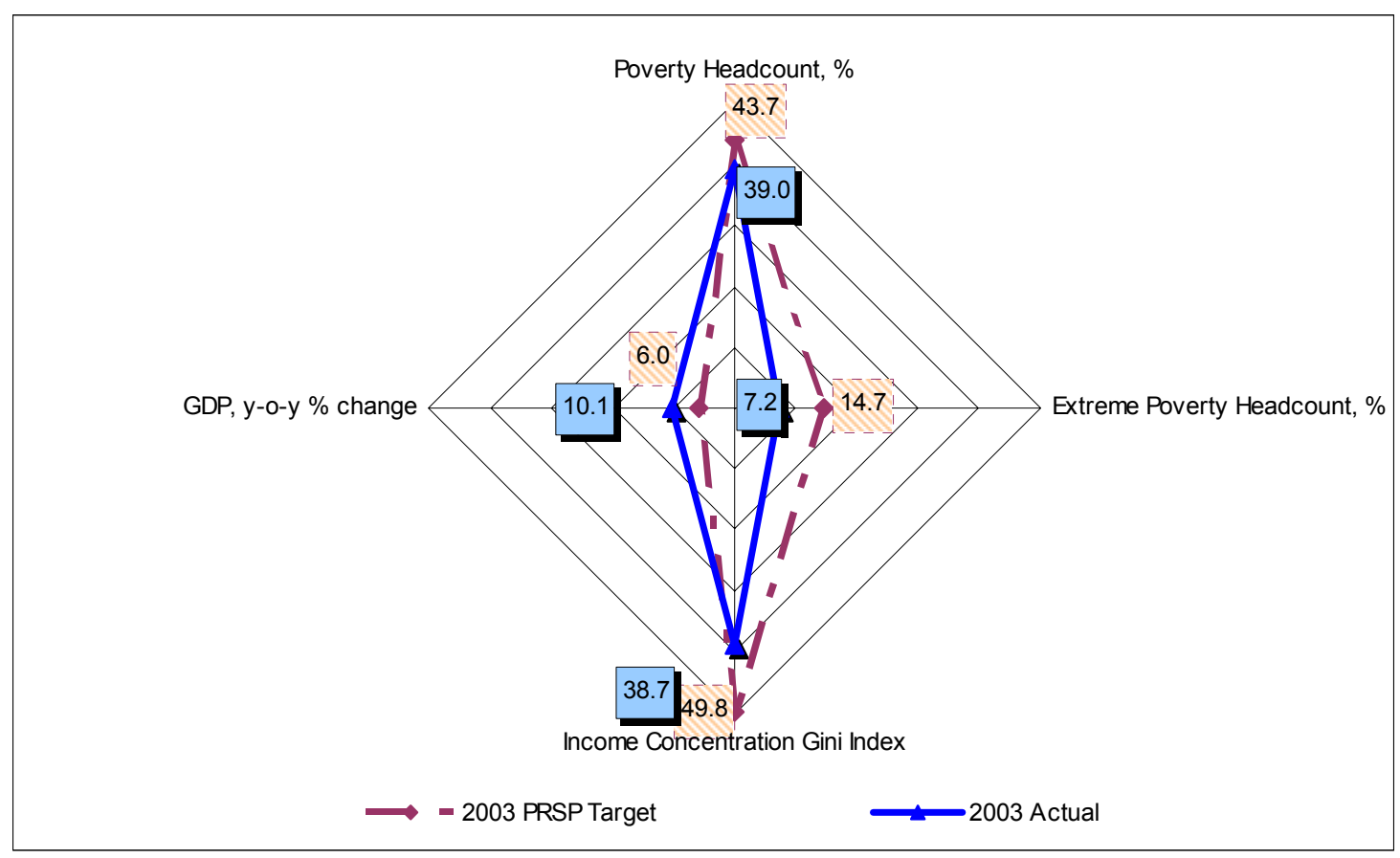

9. The 2003-2004 developments are rather encouraging, and the resulting situation is in general more favorable than it was projected under the PRSP scenario. Subsequently, during 2004, the level of poverty and the inequality in Armenia declined quicker than it was planned (Diagram 1).

10. However, parallel to the 2003-2004 positive trends, some problems emerged and the Government plans to introduce certain revisions in the forthcoming programs with the view to solve these problems. In particular, this relates to the imbalances in the regional development, as well as the life standard problems of the vulnerable social groups.

11. The report stresses the emergency of revising various sectoral policies implemented within the PRSP framework.

12. In spite of the fact that during the first years of the PRSP implementation, social expenditures of the state budget in nominal terms grew increasingly and even exceeded the PRSP targets, still it was not possible to keep the planned share of social expenditures within GDP, and during 2004 it totaled 8.35\%, instead of the planned 9.3\%. The Government should take steps to solve this problem.

13. In terms of enhancing public financing, solution of the problems associated with the tax administration is of prior importance, and here the Government should further 
consolidate its efforts in order to eliminate the discrepancies between the actual and the programmed indicators of the tax revenues/GDP ratio observed during the first years of the PRSP implementation.

14. Although, in 2004 certain progress has been observed in the area of drinking water supply in terms of declined share of the households consuming transported water, still this problem remains among the most urgent ones, the works to this end should continue, and if necessary, adequate revisions should be introduced in the PRSP.

15. The 2004 household survey results indicated that about $5.5 \%$ of the urban households did not heat their houses during winter. The problem becomes more acute when we consider that the incidence of diseases among the households, which do not heat houses during winter is two times higher than the average level. Moreover, the number of the households that do not heat houses is twice higher among the poor households2, which proves that the main reason for not heating the house is that the poor families can not afford that. Thus, during the next PRSP update, the Government should pay special attention to the problem of heating, especially in urban areas.

16. In the agricultural sector, the problems of agricultural insurance and the limited possibilities of farmers to take credits need to be addressed during the next PRSP update. At the same time, the Government should once again review the possible negative impact of the land amalgamation on the poverty.

17. Some problems emerged during overview of the 2002-2004 PRSP monitoring indicators provided by the Government, due to which it was not possible to fully collect data on the 2001-2004 PRSP monitoring indicators, as well as set benchmarks for all the indicators for upcoming years. Hence, following the forthcoming PRSP update, it would be necessary to make certain clarifications in the system of the PRSP monitoring indicators, taking into account the new provisions resulting from the PRSP update, as well as the problems, which emerged during the overview of the new indicators.

18. During the next PRSP update the Government will not confine itself to only the above-mentioned issues. It would also review other issues indicated in this paper and raised by the non-government sector.

19. At the same time, during the PRSP update, the Government will review the possibility of changing the absolute poverty and food lines, which serve as a basis for the poverty

\footnotetext{
${ }^{2}$ See the UNDP report "Human Poverty and Poverty Oriented Policy in Armenia"
} 
assessment, based on the new methodology implemented by the National Statistic

Service during the 2004 household survey.

\section{PRSP Objectives of Poverty and Inequality Reduction and 2001-2004 Main Developments}

\section{General Picture of Poverty and Inequality}

20. The first years of the PRSP implementation have evidently resulted in the significant reduction of both poverty and the extreme poverty (Table 1).

Table 1. 1999-2004 Selected Poverty Indicators

\begin{tabular}{|c|c|c|c|c|c|c|c|c|c|}
\hline & 1999 & 2001 & 2002 & \multicolumn{3}{|c|}{2003} & \multicolumn{3}{|c|}{2004} \\
\hline & \multicolumn{3}{|c|}{ Actual } & actual & PRSP & $\begin{array}{l}\text { Act. } V S \\
\text { PRSP }\end{array}$ & actual & PRSP & $\begin{array}{l}\text { Act. } \\
\text { VS } \\
\text { PRSP }\end{array}$ \\
\hline GDP per capita in dram & 305.8 & 365.8 & 424.2 & 505.9 & 489.0 & 103.4 & 590.1 & 533.0 & 110.7 \\
\hline GDP per capita in US\$ & 571.4 & 659.1 & 739.9 & 874.1 & 780.0 & 112.1 & 1106.1 & 904 & 122.4 \\
\hline $\begin{array}{l}\text { Number of poor in percent to } \\
\text { total population }\end{array}$ & 55.1 & 50.9 & 49.7 & 42.9 & 46.2 & 92.8 & 39.0 & 43.7 & 89.2 \\
\hline $\begin{array}{c}o / w: \text { extremely poor in } \\
\text { percent to total } \\
\text { population }\end{array}$ & 22.9 & 16.0 & 13.1 & 7.4 & 15.2 & 48.6 & 7.2 & 14.7 & 49.0 \\
\hline $\begin{array}{l}\text { Income concentration Gini } \\
\text { coefficient }\end{array}$ & 0.570 & 0.528 & 0.449 & 0.434 & 0.51 & 85.1 & 0.387 & 0.498 & 77.7 \\
\hline $\begin{array}{l}\text { Income of } 20 \% \text { poorest } \\
\text { population in percent to income } \\
\text { of } 20 \text { most wealthy population }\end{array}$ & 3.6 & 5.8 & 6.8 & 7.5 & 6.9 & 108.7 & 9.4 & 7.4 & 127.0 \\
\hline Memorandum items & & & & & & & & & \\
\hline $\begin{array}{l}\text { Number of people permanently } \\
\text { living in Armenia (end of year) } \\
\text { in thousands }\end{array}$ & 3215.3 & 3212.9 & 3210.3 & 3212.2 & $\ldots$ & $\ldots$ & 3215.8 & & \\
\hline
\end{tabular}

\section{Source : NSS, PRSP Projections}

21. Such an impressive reduction of poverty during 2001-2004 was mainly conditioned by a progressive growth of the labor incomes of the poor population and the social transfers. The figures show that all the main parameters set in the PRSP for 2004 have been significantly surpassed. The actual 2004 indicators could be compared to the PRSP targets set for a long-term period. In particular:

- The 2004 actual GDP per capita corresponds to the PRSP projected figure for 2007; 
- The actual figure of 39 percent of poverty observed in 2004 was planned for 2006 under the PRSP;

- The actual figure of 7.2 percent of extreme poverty observed in 2004 was planned for 2013 under the PRSP. Hence, an unprecedented reduction of the extreme poverty was evidenced during the first years of the PRSP implementation.

- The 2004 Gini coefficients for total income and consumption concentration (0.387 and 0.352 respectively) prove an unprecedented reduction of poverty. The results of the 2004 household survey show that the Gini coefficient for concentration of expenditures corresponds to the level observed during the last years of the USSR, and to the level observed in the developed European countries with low level of inequality. As for the Gini coefficient for concentration of current revenues, it is above the level planned for 2015 .

22. In this report, for the assessment of poverty the indicators calculated at the basis of the old methodology have been used. This has been preconditioned by the necessity to ensure comparability of the poverty indicators and the main PRSP targets. The results of the household surveys published by the NSS in February 2006 have been presented through the new methodology (see the annex 11), which serves a background for setting the targets of the poverty indicators during the upcoming PRSP review.

Table 2. 1999-2004 Structure of Household Cash Income

\begin{tabular}{|l|r|r|r|r|r|}
\hline Indicators & $\mathbf{1 9 9 9}$ & $\mathbf{2 0 0 1}$ & $\mathbf{2 0 0 2}$ & $\mathbf{2 0 0 3}$ & $\mathbf{2 0 0 4}$ \\
\hline In percent to total cash income & 100 & 100 & 100 & 100 & 100 \\
\hline Labor income & 35.19 & 42.33 & 53.21 & 55.2 & 56.5 \\
\hline Social transfers & 9.33 & 9.61 & 11.53 & 9.91 & 13.58 \\
\hline Income from sale of agricultural produce & 32.11 & 15.64 & 6.4 & 12.69 & 11.09 \\
\hline Transfers & 19.32 & 18.55 & 18.7 & 15.86 & 12.57 \\
\hline Other, incl. income from property & 4.05 & 13.87 & 10.16 & 6.34 & 6.26 \\
\hline
\end{tabular}

23. Table 2 shows that during 2003-2004 the main factor of poverty reduction was the progressive growth of labor income of the poor driven by the economic growth, as well as the growth of social transfers, which was envisaged under the PRSP social policies. Thus, compared to 2002 the share of labor income within the total income grew by around 3.3 percentage points, and the social transfers by around 2 percentage points. Hence, we could conclude that during 2003-204 the pro-poor orientation of the economic growth was maintained, both in terms of income primary distribution and income redistribution. 
24. Results of the 2005 first term (10.2 percent economic growth, progressive growth of the household income, further stabilization of employment, etc.) suggest that during 2005 the trends of the preceding years in poverty and inequality reduction will not change. Subsequently, during the next PRSP update the current PRSP targets in these areas should be substantially revised.

\section{Poverty in Urban and Rural Areas and by Marzes}

25. During 2004, poverty was reduced both in urban and rural areas. In the urban areas poverty level dropped by 4.3 percent, or 1.7 percentage points and totaled 38 percent. Unlike 2003, the poverty reduction in urban areas during 2004 was not conditioned by the poverty reduction in Yerevan where it remained nearly unchanged and totaled 29.4 percent as compared to 29.6 percent in 2003 . The drop of poverty in urban areas was caused by a 3 percent decline in other cities. Subsequently, the imbalances between the poverty levels in Yerevan and other cities declined3. Compared to 40.7 percent in 2003, this figure in 2004 was 37.3 percent. Despite the fact that the imbalances was somewhat reduced, it still remains rather high, hence the Government should address this issue during the next PRSP update.

26. As for the poverty incidence in rural areas, in spite of the slow-down in the level of poverty reduction during 2001-2003 (during that period poverty declined by 2.5 percent or 1.2 percentage points), as a result of which for the first time in the history of random surveys the level of rural poverty exceed the level of urban, and the imbalances totaled 19.6 percent. However in 2004 significant progress was observed in terms of rural poverty reduction. The results of the 2004 household survey show that compared to the previous year poverty in rural area dropped by around 14.3 percent, or by 6.8 percentage points and totaled 40.7 percent. Such a reduction was mainly reflected by the growth of income and alleviation of the income distribution inequality (the income Gini coefficient in rural areas dropped by 1.3 percentage points in 2004).

\footnotetext{
${ }^{3}$ The difference between poverty levels in Yerevan and other cities in percent.
} 
Table 3. 1999-2004 Urban and Rural Poverty *

\begin{tabular}{|c|c|c|c|c|c|c|}
\hline & 1999 & 2001 & 2002 & 2003 & 2004 & $\begin{array}{c}2004 / \\
2001, \\
\%\end{array}$ \\
\hline Total poverty (poverty and extreme poverty), in percent & 55.1 & 50.9 & 49.7 & 42.9 & 39.0 & 76.6 \\
\hline including urban areas & 58.3 & 51.9 & 52.6 & 39.7 & 38.0 & 73.2 \\
\hline Including Yerevan & 55.2 & 46.7 & 43.8 & 29.6 & 29.4 & 63.0 \\
\hline Other cities & 61.7 & 56.7 & 61.9 & 49.9 & 46.9 & 82.7 \\
\hline rural areas & 50.8 & 48.7 & 45.3 & 47.5 & 40.7 & 83.6 \\
\hline including extreme poverty & 22.9 & 16.0 & 13.1 & 7.4 & 7.2 & 45.0 \\
\hline including urban areas & 23.2 & 18.3 & 15.0 & 7.9 & 8.6 & 47.0 \\
\hline rural areas & 22.6 & 11.3 & 10.2 & 6.8 & 5.0 & 44.2 \\
\hline $\begin{array}{l}\text { Average monthly income of households in rural areas, in } \\
\text { dram }\end{array}$ & 8636 & 11843 & 7027 & 9960 & 11057 & 93.4 \\
\hline $\begin{array}{l}\text { Average monthly income of households in urban areas, in } \\
\text { dram }\end{array}$ & 7397 & 10913 & 11656 & 15647 & 16495 & 151.2 \\
\hline $\begin{array}{l}\text { Average income in rural areas vs average income in urban } \\
\text { areas }\end{array}$ & 116.8 & 108.5 & 60.3 & 63.7 & 67.0 & \\
\hline General poverty line dram/month & 11735 & 12019 & 12261 & 12629 & 14595 & 121.4 \\
\hline Food poverty line dram/month & 7194 & 7368 & 7516 & 7742 & 8954 & 121.5 \\
\hline Poverty depth in percent & 19.0 & 15.1 & 13.5 & 8.9 & 9.9 & 65.6 \\
\hline Poverty acuteness in percent & 9.0 & 6.1 & 5.2 & 2.8 & 3.5 & 57.4 \\
\hline
\end{tabular}

*Calculations are made on per capita basis

Source: 19998/99, 2001, 2002, 2003 and 2004 household surveys

27. Imbalances between income in urban and rural areas is still significant, and in 2004 it was equal to 33 percent. However, in terms of absolute income the imbalances in 2004 were equal to only 13 percent, reflected by a big share of "consumption of own made food" in the income structure in rural areas (around $27 \%$ of the total income).

28. Like in previous years, in 2004 the poverty was higher in marzes with predominantly rural population and unfavorable agricultural conditions. The relatively high level of poverty in Shirak marzt is a subject for a separate discussion, as it is nearly twice as high as the average figure in Armenia.

29. Although the PRSP does not provide target indicators for the marzes, still during the next update the Government will develop specific measures in its territorial policy aimed at accelerating the economic development and reducing the poverty in the most impoverished districts. 
Table 4. Poverty by Districts in 2004*

\begin{tabular}{|c|c|}
\hline Districts & $\mathbf{2 0 0 4}$ \\
\hline Percent of poverty in Shirak marz & 58.0 \\
\hline Ranking by the level of poverty & 1 \\
\hline Percent of poverty in Gegharkunik marz & 51.6 \\
\hline Ranking by the level of poverty & 2 \\
\hline Percent of poverty in Aragatsotn marz & 47.8 \\
\hline Ranking by the level of poverty & 3 \\
\hline Percent of poverty in Kotaik marz & 47.4 \\
\hline Ranking by the level of poverty & 4 \\
\hline Percent of poverty in Armavir marz & 46.8 \\
\hline Ranking by the level of poverty & 5 \\
\hline Percent of poverty in Vayots Dsor marz & 38.3 \\
\hline Ranking by the level of poverty & 6 \\
\hline Percent of poverty in Ararat marz & 36.7 \\
\hline Ranking by the level of poverty & 7 \\
\hline Percent of poverty in Siunik marz & 34.5 \\
\hline Ranking by the level of poverty & 8 \\
\hline Percent of poverty in Lory marz & 33 \\
\hline Ranking by the level of poverty & 9 \\
\hline Percent of poverty in Tavush marz & 26.7 \\
\hline Ranking by the level of poverty & 11 \\
\hline Percent of poverty in Yerevan & 29.4 \\
\hline Ranking by the level of poverty & 10 \\
\hline
\end{tabular}

* Marzes are placed in the order of poverty decline Source: 2004 household survey

\section{3-2004 Poverty Descriptions of Socially Vulnerable Groups}

30. Despite the poverty reduction during 2003-04, poverty in Armenia still continues to have a significant unit weight, as $40 \%$ of population are still poor. The phenomena of poverty is peculiar and can be also expressed in terms of vulnerable groups (Table 5).

31. As table 5 shows, during 2004 poverty declined among all the socially vulnerable categories. The highest drop was observed among the single pensioners, where the poverty in 2004 dropped by around $23 \%$ as compared to 2003. In general, single pensioners are the only category among the socially vulnerable groups where the level of poverty is significantly lower (around 2.7 times) than the average republican indicator. Such a considerable decline of poverty in this group has been mainly reflected by the policy of pensions increase envisaged under the PRSP. During 2004, the average monthly pension totaled 8,841 dram, which is by $12 \%$ more than the PRSP target. 
Table 5. 2003-2004 Poverty of the Socially Vulnerable Groups*

\begin{tabular}{|c|c|c|c|c|c|}
\hline & \multicolumn{2}{|c|}{2003} & \multicolumn{2}{|c|}{2004} & \multirow{2}{*}{$\begin{array}{c}2004 \\
/ \\
2003, \\
\%\end{array}$} \\
\hline & percent & $\begin{array}{l}\text { Deviation } \\
\text { from the } \\
\text { average }\end{array}$ & percent & $\begin{array}{l}\text { Deviation } \\
\text { from the } \\
\text { average }\end{array}$ & \\
\hline Fasmilies with an unemployed breadwinner & 48.9 & 114.0 & 48.1 & 123.3 & 98.4 \\
\hline Families consisting of 6 and more members & 57.0 & 132.9 & 53.8 & 137.9 & 94.4 \\
\hline Families with pensioneers & 46.8 & 109.1 & 41.9 & 107.4 & 89.5 \\
\hline Single pensioneers & 18.7 & 43.6 & 14.4 & 36.9 & 77.0 \\
\hline Families with 3 and more children (0-14 years age) & 66.1 & 154.1 & 61.0 & 156.4 & 92.3 \\
\hline Families with a female breadwinner & 43.3 & 100.9 & 40.3 & 103.3 & 93.1 \\
\hline Families with children below 5 years age & 53.9 & 125.6 & 52.7 & 135.1 & 97.8 \\
\hline Average republican & 42.9 & 100.0 & 39.0 & 100.0 & 90.9 \\
\hline
\end{tabular}

* Calculations per capita

Source: 2003 and 2004 household survey

32. Table 5 shows that in the remaining 6 groups poverty has also declined in 2004 , still it is higher than the average republican level. Furthermore, nearly in all the 6 groups the deviation from the average republican level grew, confirming that the vulnerability or the absolute and relative risks in these groups have grown.

33. In these groups the most vulnerable in 2004 remained the families with 3 and more children (0-14 years age), in which the poverty incidence was 56 higher than the average republican level, followed by families consisting of 6 and more members $-38 \%$ higher, and families with children below 5 years age $-35 \%$ above the average republican level. Basically, in all the three groups the level of vulnerability was conditioned by the factor of children.

34. In future it would be necessary to continue the policy of directing family benefits to children, and the resources received from the increased scope of benefits' financing - to increasing the amount of premium per child.

\section{Poverty reduction strategy}

\section{Sustainable Economic Growth and Institutional Reforms}

\section{Major Economic Developments and 2005 First Term Development Trends}

35. Economic Growth. During 2004 Armenia recorded 10.1 percent GDP growth, keeping in track with the robust economic growth of the last few years. This is 
$-15-$

significantly higher figure than the 6 percent projected under the PRSP main scenario. Nearly all the main sectors of the economy contributed to that growth, which had a positive impact over the equality of income distribution, especially in terms of income from employment.

36. Although the economy increased steadily during the last years, and two digit indicators of growth have been recorded during 2001-2004 (around 11.7 average annual), still the sectoral developments to a some degree deviated from the trends of previous years.

37. Although, during previous two years the growth was mainly driven by the industry and the house construction sector with huge cash inflows from abroad, the picture has slightly changed in 2004, and the role of the agricultural sector, the domestically financed house construction and services became more important.

38. Unlike the previous years, in 2004 a strong growth was observed in the agricultural sector, due to favorable weather and the increased arable lands, as well as certain growth of productivity in the sector. The value added in the agricultural sector grew by $14.5 \%$ and accounted for 3.1 percentage points of GDP growth.

39. The value added in the house construction sector grew by $13.4 \%$ in 2004 , accounting for 2.1 percentage points of the 10.1 percent GDP growth observed in 2004. Investments in the private and public sectors facilitated the growth. Within the house construction financing the share of households totaled $58.3 \%$ while the share of companies and the state budget funds made up $28.1 \%$ and $7.1 \%$ respectively.

40. In 2004, the contribution of the industrial sector in GDP growth was minor - only 0.4 percentage points. The value added in this sector grew only by $2.1 \%$. Such a low rate of growth was conditioned by several factors. Thus, during 2004 the total growth in the sector excluding diamond production totaled 7.0\%. Growth was registered in the chemical production (54.6\%), mining industry (100.5\%), and in the sectors of electricity, gas and water production and supply (9.9\%).

41. The role of the house construction in the total growth was significant and accounted for 4.3 percentage points of $10.1 \%$ total economic growth. In particular, during 2004 $16.9 \%$ growth was observed in the sector of transport and communications, as compared to $80.3 \%$ in the previous year, while the growth in the sectors of trade and public food amounted to $10.5 \%$ as compared to $14.1 \%$ in the previous year. 
Table 6. Selected Economic Indicators. Actual vs Programmed

\begin{tabular}{|c|c|c|c|}
\hline & \multirow{2}{*}{$\begin{array}{c}2003 \\
\text { Actual }\end{array}$} & \multicolumn{2}{|c|}{2004} \\
\hline & & PRSP & Actual \\
\hline \multicolumn{4}{|l|}{ National income and prices } \\
\hline Real GDP in percent to previous year & 14.0 & 6.0 & 10.1 \\
\hline GDP dram billion & 1,625 & 1,609 & 1,896 \\
\hline GDP US\$ million & 2,807 & 2,731 & 3,555 \\
\hline GDP per capita US\$ & 874 & 904 & 1106 \\
\hline Average CPI in percent to previous year & 4.7 & 3.0 & 7.0 \\
\hline AMD/US\$ average exchange rate & 578.8 & 589.3 & 533.5 \\
\hline Value added by major sectors & \multicolumn{3}{|c|}{ In percent to previous year } \\
\hline Industry & 15.6 & 8.0 & 2.1 \\
\hline Agriculture & 4.2 & 2.8 & 14.5 \\
\hline Construction & 45.5 & -0.4 & 13.4 \\
\hline Transport and communicatioons & 8.3 & 6.0 & 16.9 \\
\hline Trade & 14.1 & 11.4 & 10.5 \\
\hline Other & 8.6 & 6.8 & 12.1 \\
\hline Consunption and investments & \multicolumn{3}{|c|}{ In percent to $G D P$} \\
\hline End consumption & 93.5 & 94.6 & 94.7 \\
\hline$o / w:$ private & 83.3 & 82.9 & 84.0 \\
\hline Gross capital accumulation & 24.3 & 20.6 & 24.0 \\
\hline$o / w:$ public & 5.2 & 5.4 & 3.2 \\
\hline \multicolumn{4}{|l|}{ Fiscal sector } \\
\hline Consolidated budget & \multicolumn{3}{|c|}{ In percent to $G D P$} \\
\hline Total revenues and grants & 21.5 & 21.5 & 19.4 \\
\hline$o / w:$ tax revenues & 17.2 & 18.8 & 17.2 \\
\hline grants & 3.2 & 2.1 & 0.7 \\
\hline Total expenditures and net lending & 22.4 & 24.1 & 21.1 \\
\hline$o / w:$ current exopenditures & 16.7 & 18.3 & 17.1 \\
\hline Capital expenditures & 5.2 & 5.4 & 3.4 \\
\hline ĐBalance & -0.9 & -2.6 & -1.6 \\
\hline External sector & \multicolumn{3}{|c|}{ In percent to GDP unless stated otherwise } \\
\hline Exports of goods and services & 32.1 & 30.7 & 27.4 \\
\hline Imports of goods and services & 50.0 & 46.0 & 42.5 \\
\hline Current account balance & -6.8 & -5.8 & -4.5 \\
\hline Public foreign debt & 38.3 & 40.4 & 30.4 \\
\hline $\begin{array}{l}\text { Gross international reserves (end of year) } \\
\text { in months of import coverage }\end{array}$ & 4.3 & 4.6 & 4.3 \\
\hline
\end{tabular}

Source: NSS, MFE, PRSP projections 

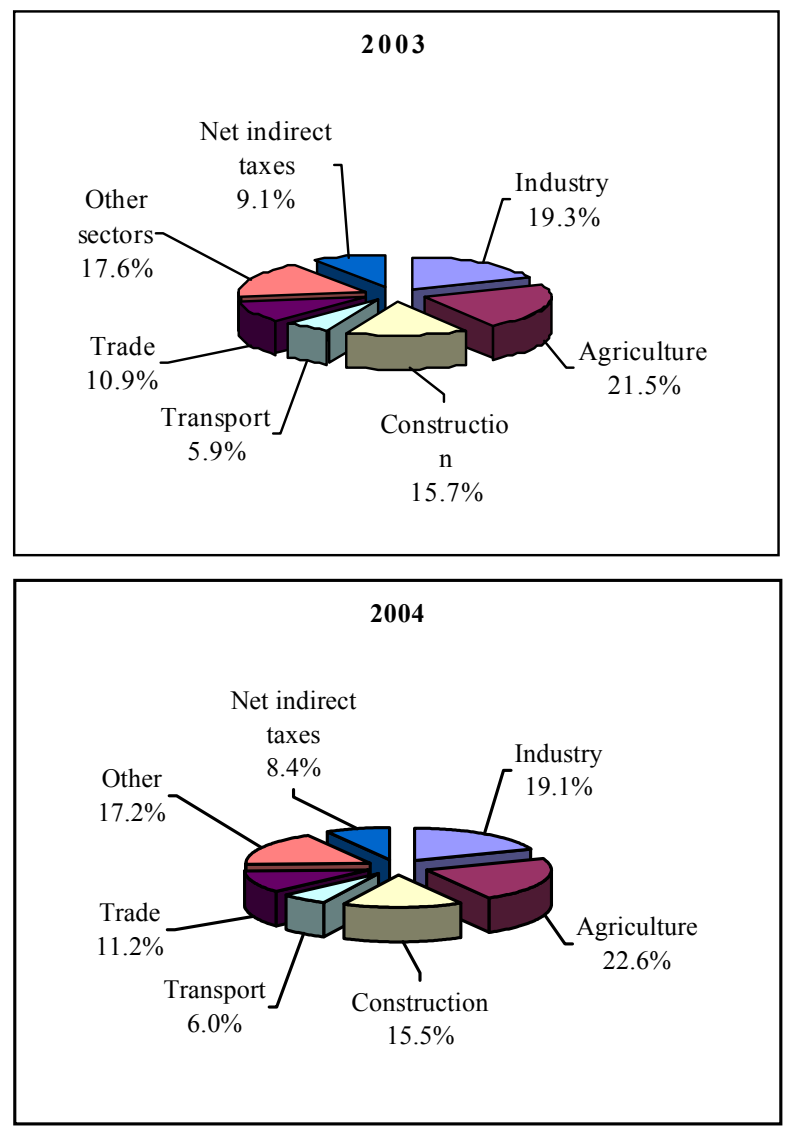

42. Referring to the GDP components by type of use, we should mention that compared to the previous year both the end cionsumption and gross capital accumulation expenditures have increased by $10.9 \%$ and $12.3 \%$ respectively. During the same period, end consumption expenditures totaled $94.7 \%$ of GDP, and gross capital accumulation expenditures $24.0 \%$ of GDP.

43. GDP per capita in 2004 totaled 590,056 drams (US\$ 1,106) and in nominal terms grew by $17 \%$.

44. Prices, salaries and exchange rate. During 2004, 2\% deflation was registered as compared to $3 \%$ set by the CBA, and the average annual inflation totaled $7 \%$, as compared to $7.7 \%$ programmed. This figure is significantly higher than the $3 \%$ average was affected by a number of external factors, such as a significant growth of private transfers, inflation of the US\$ and growth of petrol prices. While private transfer and petrol prices fostered inflation, the deflation of dram given US\$ depreciation lowered petrol prices, and this directly constrained the price growth. The average monthly 
salaries in the economic sector totaled 43,445 drams in 2004 , growing by $24.9 \%$ as compared to 2003 . This indicator is by around $35.4 \%$ higher than the average monthly salary projected under the PRSP main scenario of 32,078 drams. During 2004, the dram/US\$ exchange rate showed a tendency of deflation, while under the PRSP inflation was programmed. During 2004, the dram/US\$ exchange rate deflated by $7.8 \%$.

45. Public finances. Execution of the 2004 state budget was in track with the approved budgetary program. Revenues and expenditures of the consolidated budget in nominal terms grew by 5.6 and $10 \%$ respectively, totaling 368.6 drams and 399.8 million. The bulk of revenues came from tax collections, and within expenditures, among others, the social sector expenditures were prioritized. Still, the nominal growth of revenues and expenditures was lower than the nominal GDP growth. As a result, imbalances were observed in the ratios between actual and programmed results and GDP. In particular, the 2004 actual revenue-GDP and nominal revenue-GDP ratios declined by 2.1 and 1.3 percentage points respectively as compared to 2003 , and estimated at 19.4 and $21.1 \%$ respectively. The high GDP growth was not reflected directly in tax revenue behavior, which remains unchanged, around 17.2 percent. This was mainly because the GDP growth was much higher than programmed, mainly driven by the tax exempt agricultural sector. At the same time, the Government considers improvement of tax administration as one of the main sources for enhancing tax revenues and will continue to take measures in this direction. While the share of general expenditures in GDP has dropped, the share of current expenditures grew by 0.4 percent as compared to 2003 and totaled $17.1 \%$ in 2004 . Compared to 2001 , budget balance improved significantly and the share of budget deficit in GDP dropped from 4.5 to around $1 \%$ in $2002-2003$ and $1.6 \%$ in 2004.

46. External Sector. One of the main prerequisites of the growth in Armenia is the deepening of integration with the international economy. This factor and namely the growth of export of goods and services has significantly influenced the economic growth of the recent years. The degree of economic openness (foreign turnover of goods and services-GDP ratio) totaled around $70 \%$ in 2004. The GDP growth, the development of the respective infrastructures, and favorable international prices served as the main sources for the growth of export of goods - exports totaled US\$ 723 million and grew by $5.4 \%$, while imports totaled US\$ 1,3561 million and grew by $5.6 \%$. The negative balance of current account estimated at US\$ 161.1 million, dropping by $14.7 \%$ as compared to the previous year and significantly reducing its share in GDP to 4.75 as 
compared to $6.7 \%$ in 2004 . The improvement of current account was mainly determined by net current transfers, as compared to previous year private transfers grew significantly, totaling US\$269.4 million. The growth of negative balance of goods and services, as well as the decrease of net seasonal income contributed to the growth of BOP current account deficit by 12.6, 1.3 and 30.5 percentage points respectively. According to the data from the Customs Committee, during 2004 foreign trade turnover totaled US\$ 2,073.6 million, growing by $5.5 \%$ vs previous year.

47. State foreign debt. One of the significant achievements of the recent years is the reduction of the state foreign debt parallel to the reduction of state budget deficit. In 2004 the "debt against assets" swap was concluded, as a result of which the Russian debt was fully covered. Compared to $42 \%$ foreign debt of the previous 3 years, in 2004 it estimated at $30.4 \%$ of GDP.

48. Developments in the first term of the year 2005 suggest that the performance would be better than it was projected under the PRSP. First of all this refers to the main macroeconomic and financial poverty indicators, as well as the main factors conditioned by the latter. Developments of the previous year, as well as favorable expectations for the current year would necessarily cause the adjustment of the PRSP main targets with the view to ensuring the effectiveness of the execution, monitoring, evaluation and future revisions of the PRSP.

49. During the first term of 2005 the economy grew faster then it was planned. The real GDP growth, compared to the same period of the previous year, totaled 10.2 (the PRSP planned for $6 \%$ annual growth). The growth was mainly driven by the services and construction sectors (around 3.8 and 2.9 percentage points respectively), although the industrial, agricultural and constructions sectors also grew (by 4.6, 10.2 and $27.8 \%$ as compared to the first term of the previous year).

50. In the sector of public finances the 2005 developments in general were in line with the annual budget program. Compared to the same period of the previous year, the changes were of a positive nature, the nominal state budget revenues grew by $25.7 \%$, and the expenditures by $21.6 \%$. Notable is that the growth of revenues was fully conditioned by the domestic revenues (tax revenues in particular).

51. Compared to the annual program, change of consumption prices during the first term of 2005 was higher. Compared to the same period of the previous year the price growth totaled 2.3 percent (the program envisaged $3.4 \%$ annual growth). The growth was mainly conditioned by the growth of food (3.4\%). Still, like in the previous year, the real 
income growth of population continued.

52. The biggest (and the most sudden) deviation from the program was in the exchange rate behavior. During the first six months of the year dram continued to deflate. According to the results of the first term of the year the nominal deflation of dram against US\$ was $17.1 \%$. Although a separate research is needed in order to assess the possible impact of such developments over the population life standards, still the first impression is that the population (especially the poor categories of consumers) were not much affected (sometimes the affect might be even positive) by this, particularly in the short-term period.

\section{$\underline{\text { Business Environment }}$}

53. The prerequisite of the country's development is the gross product, the size of which is directly dependant on the business and investment environment, and the changes which occur in these fields. As a result of the economic reforms more than $70 \%$ of GDP is provided by the private sector, the viability of which depends on the existing business environment.

54. During the reporting period, the Government pursued investment policy aimed at formation of a favorable business environment, identification of the comparative advantages of Armenia and increasing the investment volumes. On April 21, 2005 the Government approved the concept paper "The RA Investment Policy", which has the purpose of increasing the transparency of the investment policy and fixing its main principles and directions.

55. Due to the measures aimed at improving the business environment and eliminating the existing obstacles, the situation has improved to a certain degree.

56. In particular, by the government decree of September 30, 2004 No1380-N a program on "Strengthening Competition in the Private Sector and Improving the Business Environment" was adopted, which provides a number of measures, such as introduction of tax and customs self-assessment systems, regulation of the VAT refund issues, improvement of tax control, formation of the institute of administrative courts, and developing legal norms for standardization and measurements as well as for enforcing the labor code.

57. One of the most important elements of improving the investment and business environment is to ensure equal conditions for competition for all the participants. The 
newly founded companies which are deprived of equal conditions are destined to closure, which may lead to a formation of monopolistic markets, where the acquisition of super profits will be accompanied with the low quality of goods and services.

58. The law on making amendments to the law on protection of economic competition is aimed at addressing these issues as it rules out discrimination of the economic entities, streamlines the responsibilities for unfair competition, through the introduction of a system of penalties.

59. During the reporting period the procedures of the enterprise state registration and licensing improved, as a result of which the average time spent by enterprises for state registration totaled 16 days in 2004, decreasing by 2.6 days as compared to the previous year, and the average time spent for obtaining a license was reduced to 16.5 days from the earlier 20.1 days. At the same time, the fees for registration and licensing were significantly lowered.

60. While the process of enterprise registration is constantly improving, the process of enterprise liquidation continues to cause many problems for the entrepreneurs. As a result the number of the enterprises is artificially increased which leads to errors in the development of the economic policy.

61. Certain work has been carried out in the direction of increasing the efficiency of the court awards and their enforcement, ensuing the transparency of enforcement processes and eliminating obstacles in the process of transferring to commercial banks the collaterals of the non-paying borrowers, as a result of which an increased confidence towards the court awards and their execution is expected, which in turn might lead to the reduction of obstacles in such economic relationships as for example is the extension of bank loans, financial mediation and the growth of the banking credits. Still the quantitative indicators of the banking development do not testify and qualitative changes in these area.

62. The existence and the development of the mechanisms of property right protection, contract execution and the respective responsibilities are an important factor for the development of the business environment. Positive changes can be accelerated if the law on bankruptcy and the relevant legal norms would become practicable. Increasing the efficiency and affordability of the judicial system would make it possible to put the entrepreneurial relations into legal grounds, thus increasing the level of selfconsciousness of the businesses.

63. As a result of adopting a new labor code, the labor relations were put into a 
qualitatively new level. The code is in force since June 21, 2005. Within one year after its adoption all the relevant legal norms and laws will be brought into compliance with the code.

64. The process of state registration of property rights underwent significant changes during the recent years, resulting in the increased transparency and removal of various investment obstacles.

65. Starting from 2002, the State Cadastre is applying the principle of one window, ensuring the accessibility of information on the processes, pricelists and time-periods through its regional offices, as well as introducing standard forms of applications for all the processes.

66. During 2004, the government took steps for working out and implementing SME development policies and strategies, and expanding cooperation between the state and the entrepreneurs. Hence, during the last 3 years around 20,000 SMEs were established, and in 2004 only around 8,500 new SMEs were established with more than 21,000 working places.

67. The activities of the SMEs and the state support are in essence covered by the existing legislation and the annual government programs of assistance. In 2002, the fund "National Center for Development of Small and Medium Enterprises in Armenia"4 with the view to assist the SMEs, and establish a viable and flexible system, which was later restructured into SME DNC non-commercial fund with state interest.

68. For the purpose of increasing the viability of the SME state assistance system, expanding the financing and investment capabilities of the SMEs, and encouraging the establishment of new companies, during 2004 pilot projects on providing loan guarantees to the SMEs were launched, and within their framework the SMEs received loans in the amount of 44.8 million drams.

69. The results of the monitoring carried out by the SME DNC showed that all the guaranteed loans were used for the purpose and the repayment risks were negligible. The profits of the borrowers grew by $20-30$ percent in average, which in turn resulted in $20 \%$ average growth of job opportunities. Presently, the Government contemplates the possibility of implementing a pilot project on subsidizing interest paid against loans, which will in essence mean a more sizable and targeted assistance to the SMEs. Still this

\footnotetext{
${ }^{4}$ Established under government decree N282 of March 19, 2002.
} 
project will be of a limited scope. In other words, the purpose of this scheme will be to implement a mechanism of an overall "affordability", which would be a least cost bearing for the state and more efficient for the SMEs.

\section{$\underline{\text { System of Public Administration }}$}

70. The achievements of the last years in the economic and social areas confirmed that the policies implemented in the field of public management lead to certain positive effects. Like in the previous 4 years, in 2004 the reforms in the area of public management were among the priorities of the Government. The stage by stage programs embraced restructuring of the ministries, governmental departments, territorial administration and local governments, and introduction and improvement of the systems of the civil and community services.

71. The charters of the ministries were streamlined, and the cross-lapping, inefficient, and not typical functions, as well as the structures which implemented them were eliminated. In all the ministries and the territorial governments civil services were introduced, that is civil service, political, conceptual and civil positions.

72. The salaries of the civil servicemen have been constantly growing - pursuant to 20062008 medium-term expenditure program of the government, during 2006 it is planned to increase the basic official salary rate by $50 \%$, which made up 30 thousand drams.

73. During 2004, the Government developed and adopted law on electronic documents and electronic digital signature, with the view of introducing the system of the electronic control over the electronic circulation and execution of decisions in the state bodies.

74. The reforms in the sector of local governments are aimed at streamlining the rights and responsibilities of the local governments, with the view of ensuring mechanisms for introducing real system of local governance. The state budget donations and the mechanisms for providing subventions and subsidies through the system of financial leveling were revised and streamlined.

75. DFID and the EU are implementing marz development projects in Tavush, Gegharkunik, Ararat and Vayots Dsor districts, with one of the main components being strengthening the capabilities of the territorial administrations.

76. During the reporting period, works continued in the area of implementing the anticorruption strategy, and regular reports were issued. 


\section{$\underline{\text { Tax and Customs Administration }}$}

77. The PRSP sets forth the main priorities of the medium-term tax policy, and at the same time introduces the following main problems, which should be solved within its framework:

- Increase the share of tax revenues within GDP;

- develop tax systems which would promote investment activities and employment, and keep maximum neutrality in terms of sustainable and high economic growth;

- keep away as much as possible from rising tax rates;

- improve tax administration, qualitatively improve relations between tax and customs authorities and the economic entities;

- further simplification of the tax system, consolidation of the existing tax laws into the tax code.

78. The PRSP medium-term tax priorities include increasing the efficiency of tax administration, and improving the management of tax control system. Furthermore, within the context of the PRSP, the increase of the tax administration efficiency is viewed as reduction of state expenditures on tax control over tax payments, and reduction of the indirect expenditures of the taxpayers for paying taxes (tax calculation and tax statements).

79. For the purpose of improving the tax administration the government set the 4 main priorities for the activities of the STS:

- reduce tax arrears

- reduce tax credits

- improve social contribution collections

- increase the efficiency of tax control over the largest taxpayers

80. Within the context of PRSP the improvement of tax and customs administration and policies is viewed as a means for setting conditions which would allow to achieve 0.30.4 percent GDP annual growth. One of the main prerequisites of the sustainable economic growth should be to ensure the growth of tax revenues through enhancing tax administration and simplifying the tax system.

81. Although the tax revenues of the consolidated state budget in nominal terms have been constantly growing during the recent years, and even exceeded the PRSP target, still this growth was not sufficient to reach the level of tax revenues share in GDP planned under the PRSP. In particular, during 2004, the tax revenues/GDP ratio was by around 1.6 
percentage points lower than it was programmed. In this context, during the next PRSP update, the Government will take additional steps with the view of ensuring the PRSP targets in the areas of tax and customs administration.

\section{Poverty Reduction Targeted Policy in Individual Spheres}

\section{$\underline{\text { Social Protection System }}$}

82. Social policy plays crucial role in terms of reducing inequality and material poverty within the frames of PRSP. Enhanced targeting in the family benefit system is considered a social assistance priority and a key instrument to reduce poverty among the most vulnerable segments of the population. Besides, the program emphasizes the provision of targeted and high quality social services to those groups of the population who need special protection (the disabled, orphans, refugees and the homeless). In the sphere of social insurance, the policy aims to enhance the system's efficiency, to increase pensions, to implement insurance in case of unemployment, as well as better differentiate the pensions depending on the length of service, to introduce the system of individual registration, and to ensure the transition to a pension system based on the amount of insurance payments made in the past.

Table 8. Consolidated budget expenditures on social protection and social insurance in 2003-2005

\begin{tabular}{|c|c|c|c|c|c|c|}
\hline & 2003 & 2004 & 2005 & 2003 & 2004 & 2005 \\
\hline & \multicolumn{3}{|c|}{ PRSP } & \multicolumn{2}{|c|}{ Actual } & Budget \\
\hline in $\%$ of $G D P$ & 4.8 & 5.1 & 5.4 & 4.5 & 4.5 & 5.35 \\
\hline year-on-year \% change & 18.4 & 15.8 & 13.8 & 19.7 & 16.9 & 32.2 \\
\hline \multicolumn{7}{|l|}{ of which: } \\
\hline State Budget, billion drams & 30.5 & 36.1 & 41.4 & 29.3 & 34.3.5 & 46.7 \\
\hline in $\%$ of $G D P$ & 2.1 & 2.2 & 2.35 & 1.8 & 1.81 & 2.2 \\
\hline in $\%$ of total expenditures in the sector & 42.8 & 43.7 & 44 & 40.1 & 40.2 & 41.3 \\
\hline year-on-year \% change & 29.6 & 18.2 & 14.7 & 23.0 & 17.2 & 33.8 \\
\hline State Social Insurance Fund, billion drams & 40.8 & 46.5 & 52.6 & 43.2 & 51 & 65.4 \\
\hline in $\%$ of $G D P$ & 2.8 & 2.9 & 3.0 & 2.7 & 2.7 & 3.1 \\
\hline in $\%$ of total expenditures in the sector & 57.2 & 56.3 & 56 & 59.2 & 59.7 & 57.9 \\
\hline year-on-year \% change & 11.1 & 13.9 & 13.1 & 17.6 & 18.1 & 28.2 \\
\hline
\end{tabular}

Expenditures of the State Social Insurance Fund on system maintenance and development are excluded.

Source: National Statistical Service, State Social Insurance Fund, Ministry of Finance and Economy, and PRSP projections 
83. Public expenditures for social protection and social insurance have been planned according to the PRSP priorities and the targets of public expenditures in this sector. Allocations to this sector from the 2004 consolidated budget were 85 billion drams. This figure exceeds the same indicator for 2003 by $17 \%$.

84. In 2004 , expenditures in family benefits totaled 16.1 billion drams ( $0.9 \%$ of GDP), or $18.2 \%$ of public spending in the sector. As guided by the PRSP priorities and policies, the 2004 budgeted allocations for this sector have significantly increased (see Table 9).

Table 9. Expenditures on Family Benefits in 2003-2005

\begin{tabular}{|c|c|c|c|c|c|c|}
\hline & 2003 & 2004 & 2005 & 2003 & 2004 & 2005 \\
\hline & \multicolumn{3}{|c|}{$P R S P$} & \multicolumn{2}{|c|}{ Actual } & Budget \\
\hline Family benefits, billion drams & 12.7 & 16.1 & 20.21 & 12.4 & 16.1 & 20 \\
\hline in $\%$ of $G D P$ & 0.9 & 1.0 & 1.2 & 0.8 & 0.9 & 1 \\
\hline $\begin{array}{l}\text { in } \% \text { of consolidated budget total } \\
\text { expenditures }\end{array}$ & 3.4 & 4.1 & 4.8 & 3.4 & 4.0 & 4.1 \\
\hline $\begin{array}{l}\text { in } \% \text { of consolidated budget expenditures on } \\
\text { social protection and social insurance }\end{array}$ & 17.9 & 19.5 & 21.1 & 16.9 & 18.2 & 17.7 \\
\hline year to year $\%$ change & 5.5 & 26.3 & 25.5 & 2.2 & 30.0 & 24.2 \\
\hline
\end{tabular}

85. Taking into account the fact that the family banefit system has proved to be an efficient tool of poverty reduction as well as reasoning from the fact that the incomes recieved through the family benefit system continue to play an essential role in the structure of the incomes of population quantiles, parallel to the increase of the expenditures in the family benefit system the RA Government underatkes relevant steps aimed at increase of the efficiency of the system and introduction of a differentiating mechanism in the benefits provided to the families with many children, which are exposed to the risk of poverty.

86. In 2005 the family benefit marginal scoring unit was lowered by one unit- from 35.0 unit it was reduced to 34.0. It was determined that the allowance provided to minors who are members of families with a vulnerability unit between 34.01 and 38.00 will increase to 3000 drams. The allowance provided to minors who are members of families with the same vulnerability unit living in highland and border regions 3500 drams is set. The allowance provided to minors who are members of families with vulnerability unit between 38.01 and 41.00 will increase to 3500 drams, and in highland and border regions - 4000 drams. Respectively, for minors who are members of families with vulnerability unit between 41.01 and up, the allowance was set 4000 drams, and in 
highland and border regions - 4500 drams. The family benefit base amount was set 6000 drams. A new form of one-time pecuniary aid amounting 35000 drams was set to cover childbirth expenses in families entitled for family benefit.

87. As a result, average size of family benefit in 2004 was increased by $26.3 \%$ as compared to 2003 , respectively in 2005 -by $25.5 \%$ as compared to 2004 , by maintaining the number of beneficiary families.

88. Data described in Table 10 demonstrate the considerable role of the system of social transfers in poverty reduction efforts. According to the assessment if the nominal amounts of social transfers are withdrawn from poverty assessment calculation, the poverty level would amount to $49.9 \%$ in 2004 , instead of recorded $39 \%$, and the extreme poverty would amount to $18.6 \%$ instead of $7.2 \%$.

Table 10. Alteration of poverty level without payment of social assistance and social transfers

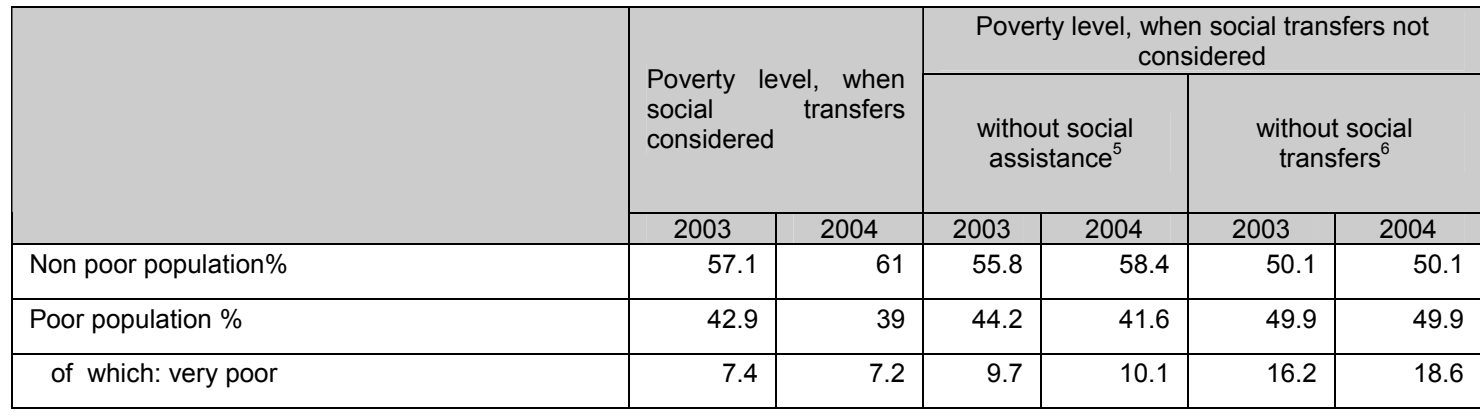

89. The UNDP assisted report of "Human poverty and poverty targeted policy in Armenia" considers the effectiveness of current system of family benefits to be an outcome of short term policy. The report offers completing the criteria of system of family benefits with human poverty indicators, and differentiating the families with equal scores by unequal opportunities to come out of poverty. It will allow bettering the concept of targeting and draw to diversified appointment of benefits by regions.

90. The social policy projected by the PRSP planned to stop the provision of resources for one- time financial aid. Nevertheless, in the current year, the Government confined to reducing those resources from $5 \%$ to $3 \%$ of the total state budget allocations set aside for this purpose. It is noteworthy that surveys conducted in this aspect have shown clauses of ineffectiveness of payment mechanisms and poor targeting of one-time financial

\footnotetext{
${ }^{5}$ Social assistance includes reimbursement against privileges, allowance for children, allowance for single mothers, unemployment allowance, scholarship allowance, family allowance, etc.

${ }^{6}$ Social transfers include the above mentioned social assistance and pensions.
} 
aids.7

91. The system of family benefits suffered some violations too. Particularly, in the outcome of monitoring and check-up of legal-applied practice implemented in 18 social service regional agencies of RA marzes and Yerevan, incorrectly appointed payments of 9.860.500 drams were recorded. $70 \%$ of the recorded violations were made through certificates given by local self-government bodies. The above mentioned corruption cases were recorded also in expertise research papers8.

92. The enforcement of RA law "on State Benefits" of 2005 will to help reduce the above mentioned violations. The law has resolved the family vulnerability assessment indices, determining their scale, as well as definitions of application circumstances.

93. The authorities continue to take up measures aimed at improving the efficiency and financial viability of the pension system. In 2004 expenditures 9 for pensions increased by about 20 percent, as compared with the previous year, and amounted to 50.9 billion drams (or 3\% of GDP).

Table 11. Consolidated budget expenditures on pensions in 2003-2005

\begin{tabular}{|c|c|c|c|c|c|c|}
\hline & 2003 & $\begin{array}{c}200 \\
4\end{array}$ & $\begin{array}{c}200 \\
5\end{array}$ & 2003 & 2004 & 2005 \\
\hline & \multicolumn{3}{|c|}{ PRSP } & Actual & Actual & Budget \\
\hline Total, billion drams $^{10}$ & 40.6 & 47.0 & 53.2 & 42.6 & 50.9 & 63.3 \\
\hline in $\%$ of $G D P$ & 2.8 & 2.9 & 3.0 & 2.6 & 2.7 & 3 \\
\hline in $\%$ of consolidated budget expenditures & 10.8 & 12.1 & 12.6 & 11.7 & 12.9 & 13 \\
\hline $\begin{array}{l}\text { in } \% \text { of consolidated budget expenditures on } \\
\text { social protection and social insurance }\end{array}$ & 56.9 & 56.8 & 56.6 & 58.4 & 57.6 & 56 \\
\hline year-on-year \% change & 18.8 & 15.6 & 13.2 & 24.7 & 19.6 & 24.3 \\
\hline of which: & & & & & & \\
\hline $\begin{array}{l}\text { Labor pensions (based on payment of } \\
\text { contributions), billion drams in } \% \text { of GDP }\end{array}$ & 38.6 & 44.2 & & 40.6 & 47.9 & 60.7 \\
\hline in $\%$ of $G D P$ & 2.6 & 2.7 & & 2.5 & 2.5 & 2.8 \\
\hline Social pensions & 2.0 & 2.7 & & 2.0 & 3.0 & 2.6 \\
\hline in $\%$ of $G D P$ & 0.1 & 0.2 & & 0.1 & 0.2 & 0.12 \\
\hline
\end{tabular}

Expenditures of the State Social Insurance Fund on system maintenance and development are excluded.

\footnotetext{
${ }^{7}$ Poverty and Social Impact Assessment (PSIA) Qualitative Research, GTZ, page 12, Yerevan 2005

${ }^{8}$ Social Monitoring Qualitative Assessment Report, “Hazarashen” Armenian Center of Ethnography Research

${ }^{9}$ Excluded the budgetary financing of the pension security of the officers personnel and their family members, as well as of the ranks personnel and their family members.
} 
94. The increase of pension expenditures was driven mainly due to two factors- the increased revenues of the State Social Insurance Fund (SSIF) from mandatory social insurance payments, as well as with a subsequent separation between financing of social pensions and non insurance payments and insurance payments. Particularly, since 2003, social pensions are financed from the state budget, and since 2004, budgetary financing is also provided for the supplementary payments against employment periods and other activities included in the insured length of service, for which the state is legally bound to make social payments.

95. Improvement of the overall resource package has allowed a constant increase in the annual value of the insured length of service. This contributes to the further differentiation of the pension size depending on the length of service. Particularly, over the first three quarters of 2003, it was 100 drams (as compared to 80 drams for the third quarter of 2002), while since October it was raised to 120 drams. Since January of 2004, the annual value of the insurance length of service has been further increased to 140 drams11.

96. Activities were implemented in the reporting period of time directed at pension reforms. In December, 2004 by order of the RA President an inter-institutional working group was set up. The latter developed conceptual approaches of pension reforms and time table of pension reforms implementation. The mentioned documents were endorsed by the RA Government Decree No.666-N dated April 28, 2005, according to which a three-degree (mixed) system of pension insurance must be introduced. Taking the conceptual approaches as a basis, currently a new strategy of pension insurance is being developed.

97. Within the framework of pension insurance system reforms, preparations are in progress to introduce the individual (personalized) registration system. The effectiveness of this system and the availability of personalized reports are expected to enable the generation of reliable data on person's salary, the deposits made in favor of social payments, and on his/her insured length of service. This will allow the to make a link between salaries, accumulated insurance payments, and the future pension amount.

98. Among challenges of pension system, it is worth to highlight the legislative regulation

\footnotetext{
${ }^{11}$ According to RA Government respective decree of September 9, the value of one year of insurance length of service will total 160 drams starting from 2004.
} 
of volunteer participation of people employed in rural farms 12 in pension insurance system. In this regard, this problem will be tackled during the upcoming PRSP update.

99. As a consequence of the introduced system of social security cards, the quality and reliability of data incorporated in the functioning databases has considerably bettered. Particularly, from 540.000 data incorporated in pension information database, 355.000 needed to be corrected through comparing with the data of social security cards database.

100. Data incorporated into the family benefit database were also improved, out of 500.000 names of beneficiaries 300.000 needed to be corrected. And owing to comparisons of several stages 200.000 data were corrected as of 01.01.2005. Similar measures were implemented also with regard to databases of the disabled and unemployed. In the database of the disabled from 170.000 data100.000 needed to be corrected, from which 20.000 were corrected, and the remaining data are in the process of correction. In the database of the unemployed from 52.000 data 14.000 needed to be corrected, 10.000 were corrected.

101. The Center of Republican In-House Social Service for the Elderly and Disabled provides service to only 1200 single elderly and disabled in Yerevan. There live 11.000 single pensioners with no heirs in the republic. Apparently, there is a huge demand for increase of such services. The RA Government Decree No.485 of November 4, 1997 on expanding the in-house services of social service and organizing services in marzes of the country still has not fully been enforced.

102. To resolve the above mentioned problem, the Government suggests that implementation of certain social packages be ordered to civil society institutes. This suggestion comes from the fact of similar successful pilots projects implemented through financial assistance of donors in Armenia. For instance, "Mission Armenia" Charity NGO provided in house service to 8697 elderly, 9744 refugees 13 . Also similar proposal was made in UNDP report of "Human Poverty and Poverty Targeted Policy in Armenia"14, as well as during interim professional discussion of the present report15. The described problem/challenge will be tackled during the upcoming PRSP update.

\footnotetext{
${ }^{12}$ Since January, 2003 people employed in agricultural farms were exempted from mandatory social insurance payments

${ }^{13}$ Mission Armenia NGO official reference

14 "Human Poverty and Poverty Targeted Policy in Armenia" draft report, UNO, UNDP, page 66, 2005

${ }^{15}$ Protocol of PRSP work group expanded professional discussion, see at web site: www.prsp.gov.am
} 
103.

A necessity for implementing vigorous policy on employment was described in a range of clauses of RA Government Decree No.1225-N of August 5, 2004 "on Making Amendments and Additions in RA Government Decree No.994-N of August 8, 2003 “On Poverty Reduction Strategy Paper”. Clauses related to employment were adjusted to that policy implementation ideology. Particularly, the program that provides pecuniary aid to persons seeking for a job will be replaced by other financial assistance programs (salary reimbursement and other programs) directed at persons which are vulnerable due to non-competitiveness in the labor market. These programs will be financed through RA state budget. Thus another step is made towards policy activation.

104.

Although there is a tendency of drop of unemployment in the republic, it still continues to remain about twice higher the average in Shirak, Syunik and Lori marzes.

105. Starting from 2004 a territorial policy has been implemented in the employment aspect. And the positive impact of that was demonstrated especially within the program of "Benefit against Labor". Both the number of communities involved and that of job seekers has increased: about 11800 people were involved in the works implemented within 555 programs. In future as well, the plan is to be guided by principle of territorial-purposeful policy for implementation of both active and passive programs, as well as public works.

106. Outcomes of qualitative survey of Poverty and Social Impact Assessment (PSIA)16 (the survey was conducted in 2004 in two towns - Charentsavan and Stepanavan to find out to what extent the PRSP projected employment and family benefits policies were applied) indicate that there are still some problems in the aspect of internal monitoring ("Employment Service" agency, in monitoring its centers). The majority of the interviewed were not aware neither of their rights nor of functioning programs, and violations were made. Particularly, the names of persons registered in the program of "Benefits against Job" often do not concur with names of actually acting persons.

107. By the RA Government Decree No. 1667-N “on Making Amendments in RA Government Decree No. 235 of April 19, 1999" the base benefit for unemployment was raised, thus setting it in size of $60 \%$ of minimum monthly salary- 7.800 drams.

108. According to expertise assessment, in Armenia actual levels of both general

${ }^{16}$ German Technical Collaboration, PRSP sub-program 
and young unemployment are incomparably higher than that of recorded by employment agencies. According to labor force survey implemented in 1996, only 25 percent of the unemployed were registered in employment agencies. Such situation has remained unchanged since then. According to expertise assessment based on labor survey of 2003, the actual unemployment level exceeds the officially recorded unemployment level for about 4 times. At that, for the elderly it is about 2.5 times more, and for the young -11 times more. It should be also mentioned, apart from the described, another reason that influences the incompliance of these indices in Armenia is the following circumstance: according to the RA law "on Employment of Population", persons who do not have at least one year length of service, are not granted the status of the unemployed. Naturally, this clause refers to young population first of all, and together with other factors draws to considerable difference of registered and actual age structure of unemployment 17.

109.

It should be also mentioned that in Armenia strict deficiency and low comparability of information about labor market on the basis of labor force surveys of Armenia limits the framework and opportunities for analysis in the area of unemployment and employment18. Particularly, the indices brought in RA NIS analytical report of 2002-2003 on economically active population (on part of employment administrative statistics) are not comparable with the same indices of previous years.

110. The Government especially emphasizes children's social assistance programs. In the course of 2003 and 2004, a number of legislative acts dealing with the problems in this area were adopted. In particular, the procedure to provide a home to children deprived of parental care has been approved. Since 2003, the program to provide public assistance to graduates of children's tutoring institutions has been implemented. It aims to ensure the social protection of the 1991-2003 graduates of children's homes and their integration in society 19. Furthermore, programs are implemented to protect the rights and legal interests of children who, being deprived of parental care, are wards of the state. These programs ensure protection of rights and legal interests of children deprived of parental care, their upbringing and education in a family (or a family-like) environment, and decrease the pressure on children's homes and orphanages by

\footnotetext{
17 “Preliminary analysis of labor market- with emphasis on youth issues” report, Part A, page 52, “Avag Solutions” LTD, Yerevan 2004

18 "Preliminary analysis of labor market- with emphasis on youth issues" report, Part A, page 53, "Avag Solutions" LTD, Yerevan 2004

${ }^{19} 2004$ budget projected 335 million drams for this line as compared with 200 million drams of the previous year
} 
arranging for child placements outside such institutions.

111.

On April 8, 2004, RA Government approved Decree No. 945-N “on endorsing the national program of 2004-2010 aimed at enhancing the condition of women in RA and the list of measures of national program of 2004-2010 directed at enhancing the role of women in the society". This will help provide equal rights and equal opportunities for women and men, as well as will support regulating social-economic issues of women, thus leading to poverty reduction in the country.

112. By the RA Government Decree No.1324-N "On Recognizing the Public Administration Body Authorized by the Government of the Republic of Armenia, and on Approving the Minimum Public Social Criteria for the Care and Education of Children at Children's Home" dated August 5, 2004; and Decree No. 158 “on Approving the order of allocation of one-time pecuniary aid to graduates of Children's Homes (despite organizational legal form)" dated February 17, 2005 were also adopted. In light of introducing a system of protection of children's rights, RA Prime Minister adopted a Decree "On Approving the Timetable of Measures of Establishing a National Commission and Marz Commissions (Yerevan City Commission) for Protection of Children in Republic of Armenia" dated December 5, 2004. Also RA Government Decree No.196-N “on Approving the Annual Program of Child's Rights Protection” was adopted on January 20, 2005.

113. The Japanese T051331 Grant Program of Social Development Fund for Piloting Reforms in Child Care System was continued during 2004-2005. Community centers are projected to be opened in Yerevan and Gyumri for risk subjected children.

114. The Government continued measures directed at improving housing conditions and providing integration of refugees and the internally displaced people. Refugees living in temporary shelters in the territory of Armenia were recorded. Housing conditions of 3570 families of refugees were surveyed, 3470 families were recognized as beneficiaries. On May 20, 2004, RA Government adopted "the Priority Program of Housing Provision to Persons Deported from Azerbaijan during 1988-1999”. The problem of housing provision for 820 refugee families residing in temporary shelters will be resolved in 9 marzes of the republic in 2005-2007.

115. The Government is trying to resolve the problem of creating opportunities for refugees to run small and medium-sized business. In particular, this beneficiary group was recognized as preference group in the "2005 Program of Small and Medium-Sized Entrepreneurship". 
116. Certain problems were revealed in the current year policy run towards segments of population who need special protection. Particularly, by the Decree No.1094-N dated July 22, 2004 amendments were made in the Decree No.579 "on Approving regulations on reimbursement of damage as a result of job responsibilities of employees in enterprises, institutions and organizations (despite ownership form), professional disease and other damage caused to health" dated November 15, 1992. Clause 16 of the regulations was announced void, according to which in consequence of liquidation or reconstruction of an organization the damage is reimbursed by the legal successor (continues the damage reimbursement), and in absence of the latter- by social insurance body through state budget. As a result of the latter persons appeared in risk groups are maximum endangered and poverty targeted solution is in agenda.

\section{Healthcare}

117. The main objectives of the PRSP in healthcare are to enhance the availability and quality of health services, first of all focusing on the primary unit and on the moderation of territorial imbalances. In order to achieve the established objectives, public expenditures in healthcare are planned to increase, and actions are planned to be taken to improve the system management and efficiency.

118. In 2004, public expenditures in healthcare were mainly characterized by positive developments. 2004 indicator exceeded the respective indicator of 2003 by $26 \%$, and totaled 24.7 billion drams. The budget of healthcare totaled 21 billon drams in 2003, 25 billion drams- in 2004, and 32 billion drams in 2005. The 2004 budget was executed by 99 percent, which meant that medical institutions were fully financed under contractual commitments of the state order.

119. Although the nominal value of the 2004 public expenditures in healthcare corresponded to the PRSP targets, there were certain deviations of the health expenditures/GDP ratio, mainly reflecting the fact that the actual economic growth rate was higher than expected.

Table 12: State Budget Expenditures in Healthcare in 2003-2005

\begin{tabular}{|c|c|c|c|c|c|c|}
\hline & 2003 & 2004 & 2005 & \multirow{2}{*}{$\frac{2003}{\text { Actual }}$} & 2004 & 2005 \\
\hline & \multicolumn{3}{|c|}{ PRSP } & & Actual & Budget \\
\hline Total, billion drams & 21.0 & 24.9 & 30.8 & 19.6 & 24.7 & 32.2 \\
\hline Percent of GDP & 1.4 & 1.5 & 1.8 & 1.2 & 1.3 & 1.52 \\
\hline Percent of State Budget expenditure & 6.4 & 7.3 & 7.7 & 6.4 & 6.2 & 8 \\
\hline Percentage change, as compared with previous year & 31.2 & 18.6 & 23.5 & 22.6 & 26 & 30 \\
\hline
\end{tabular}


$-35-$

120.

Allocations to the health sector demonstrate a significantly increasing tendency; thus, per capita budgetary allocation to health totaled 7.8 thousand drams in 2004, and around 10.0 thousand drams in 2005.

121. In 2005, monthly salaries of the ambulatory/ polyclinic medical staff increased from the previous year's 36,000 drams to 46,800 drams, and those of the paramedical staff increased from the previous year's 23.000 drams to 29.900 drams.

122. Monthly salaries of the hospital medical staff was raised to 37,500 drams (from the 33.500 drams of the previous year), and those of the paramedical staff was raised to 29.300 drams (from 24.550 drams of the previous year).

123. In 2004, renovation and re-equipment works were implemented in around 80 percent of medical institutions within the system. During the reporting period, departments equipped with modern medical equipment and technologies were opened.

124. Stressing the significance of primary medical care, the government has adopted the "2003-2008 Strategy for Primary Healthcare of Population of the Republic of Armenia". It aims to improve the availability, quality and efficiency of primary medical care, particularly through introducing the system of family medicine. In this context, the Government implements measures to manage the system activities and introduce appropriate financing. Special emphasis has also been put on staff training and retraining through involvement of ambulatory-polyclinic institutions in pilot projects, in Yerevan and beyond.

125. The annually increased financing of healthcare and, in that context, considerable increase of resources directed at primary healthcare maintenance as a priority, allowed to organize free ambulatory/policlinic medical care for persons at the age of 65 and higher in all levels of primary ambulatory/policlinic services, without limiting type and volume. Also, taking into consideration high mortality rate caused by cardiac-vascular diseases, it will allow organizing complimentary cardiac service in the primary service unit. Besides, medical service quality monitoring criteria were introduced in the primary healthcare unit in 2005. And groups of population of 0-18 and of higher age have been involved in complimentary ambulatory/polyclinic care by state mandate in 2006 .

126. The system has also experienced corruption. Particularly, the volume of spent healthcare services shown by households are 4.48 times more than the volume of 
services provided by health care facilities and individual entrepreneurs2 0 at population's expense.

127. The Government led a targeted policy in medicament provision. To raise the availability of medicaments for insolvent groups of population, RA Ministry of Health developed, agreed with interested services and further approved by order No.759-N dated July 04, 2004 "the norm of providing the social groups and persons suffering from individual diseases entitled to receive free medicaments or medicaments on privileged conditions from ambulatory/polyclinic medical facilities". The above mentioned order was refined by the Order No.74 of the RA Minister of Health dated January 27, 2005. And the list of medications subject to purchase by ambulatory/polyclinic medical facilities defined by the order of 2004 was removed. That allowed organize the treatment in ambulatory/polyclinic medical facilities more effectively. As a consequence, the number of applications for medication provision directed to the RA Ministry of Health by population has dropped by $40 \% 21$.

128. Despite the measures initiated by the Government, both the physical and financial availability of medication is still a pending problem. According to expert estimates, the main part of medication required for hospital medical care is purchased by the hospital, while those required for ambulatory/polyclinic medical care are purchased from pharmacy network mainly by the visitors 22 .

129. The issue of pharmacies is poorly organized especially in rural areas. According to UNDP in about $90 \%$ of the surveyed 170 rural communities there is no pharmacy or if there is one, it is closed down. At that, about $77 \%$ of population of those communities has to purchase medication in pharmacies located in $6 \mathrm{~km}$ or even more distance away from their community. This is also shown by findings of survey implemented by Oxfam (UK) Armenian office initiated in four marzes in 2003-200423. According to the findings there are no pharmacies in the rural communities, $2 / 3$ of the population is forced to purchase medication in pharmacies of marz towns, and $10-25 \%$ in Yerevan pharmacies.

\footnotetext{
${ }^{20}$ Economy at a glance No.14 (26) Reference of Analytical- Informational Center of Economic Reforms, November 25, 2004

${ }^{21}$ Economy at a glance No.14 (26) Reference of Analytical- Informational Center of Economic Reforms, November 25, 2004

22 "Human Poverty and Poverty Targeted Policy in Armenia" draft report, UNO, UNDP, page 33, 2005

${ }^{23}$ Monitoring and Evaluation of primary medical care and situation of irrigation water in Shirak, Vayots Dsor and Syunik marzes, Massive research, Oxfam, Yerevan 2004
} 
130.

The measures to eliminate regional imbalances aim to improve the material and technical basis of medical institutions in the regions, especially in rural areas, and to equip them with modern facilities. The 2004 budget has made provisions for that purpose, and currently the process is in progress. Moreover, an objective of the program is to raise the availability of diagnostic equipment in the regions. Appropriate contracts have been concluded with the regional polyclinics to provide especially costly diagnostic services. In order to ensure the availability of emergency services in rural areas and to assign this function to the primary unit doctors, the Ministry of Health has allowed about 80 rural ambulance stations. They have been provided with ambulances through the World Bank-financed credit program. In 2004 the Ministry of Health allowed to implement emergency services by state mandate.

131. Maternal and child health, which is the PRSP priority, aims to achieve the relevant objectives of the Millennium Declaration24. While stressing these issues, the government has approved a number of key documents to implement the relevant program provisions in PRSP. In 2003, the Government approved the "2003-2015 Strategy for Maternal and Children's Health", which, among other goals, defines the objectives of reducing maternal and child mortality, and the number of under-weight neonates, ensuring a 95\% (or higher) vaccination rate, and improving the indicators of exclusive breastfeeding.

132. In this context, special emphasis is put on improving the quality of obstetric and gynecologic care and strengthening the material and technical basis of maternity hospitals. This has been appropriately reflected in public expenditures. The 2004 budget expenditures in obstetric and gynecologic care exceed the same indicator of the previous year by 20 percent. Individual delivery expenses are planned to be $44.000 \mathrm{drams}$, as compared with 36.000 drams in the previous year. Besides state funds, donor organizations and governments have been providing a sizeable input to these projects, especially in terms of dealing with regional issues 25.

133. The Government consistently implements programs to fight and prevent transmitted diseases such as tuberculosis, malaria, and AIDS/HIV. In 2003, the

\footnotetext{
${ }^{24}$ The ratio of mother and child mortality of recent years is comforting and if maintained, it will promote achieving the objectives of the Millennium Declaration. However, there exist certain statistical challenges in the process of registering the childbirth and child mortality. RA Ministry of Health, RA Ministry of Justice and RA National Service of Statistics closely collaborate to resolve those challenges.

${ }^{25}$ Particularly, with assistance of UNDP Population Fund rehabilitation mobiles have been provided to Armavir and Spitak obsteric institutions to provide emergency obsteric service. It is planned to expand such services throughout remote areas.
} 
Government approved the "National Program against Tuberculosis". It aims at the systematic prevention, detection and treatment of this disease. It also provides for antituberculosis drugs to hamper any further development of morbidity and disability among population. Although the cases of malaria are decreasing every year and the programs implemented show positive effects, additional efforts will be needed for the complete elimination of this disease. The "Program for AIDS/HIV Prevention" is implemented through activities to improve the population's knowledge of medical and hygienic factors. Preventive work among AIDS risk groups, as well as running an information center for AIDS/HIV diseases are some of the approaches used with family members, nurses, and medical staff. Voluntary units for AIDS consultation and examination are also included.

134. Improving the management and enhancing the efficiency of the system are among the key objectives of healthcare reforms. Work in this area involves institutions in both primary and secondary units. The system's optimization aims to transfer the load of healthcare services from the relatively expensive hospital unit to the relatively inexpensive primary unit. Concurrently, the government pursues the goal of concentrating its scarce resources on a minimum number of hospitals. Thus, the 2004 state mandate has been placed in a selected number of multi-profile hospitals, pursuant to the criteria developed by the Ministry of Health. In terms of enhancing the efficiency of health settings, the focus is on their enlargement through mergers- especially in Yerevan. In 2003, under the optimization program of the healthcare system in Yerevan, nine consolidated units were created through the merger of 34 healthcare institutions. The merging process was based on criteria regarding local and medical services. Implementing this process results in a more efficient combination and utilization of available capacities and staff potential.

\section{Education}

135. In the sphere of education, the PRSP major goals are to ensure the availability and to increase the quality of education, while prioritizing the area of general education. To meet these objectives, public spending in education is projected to be added, and actions are to be taken for improving the system efficiency.

136. Over recent years positive trends were observed in the dynamics of public expenditure in education. Thus, in 2004 budgetary spending in education was stipulated to comprise 2.33 percent of GDP, as compared with the 1.93 percent of GDP in 2003, and the stipulation for 2005 was 2.74 percent (the OECD average for public expenditure 
in education is 4.7 percent of GDP).

137.

In 2004, around 83.6 percent of public allocations to education were channeled

to general education, and 14.1 percent - to the financing of vocational educational programs; in 2005, these indicators equaled 84.22 and 12.44 percent, respectively, against the OECD averages of 72 and 20 percent.

138. In June 2004, while entering changes into the annual budget adopted in December 2003, an additional allocation of 7 billion drams was made to education, mostly channeled to the financing of capital expenditure for improving schools facilities in the general education network. This was the main driver of the difference between the nominal value of the PRSP targets for public spending in education and the actual 2004 budget indicators. Such a redistribution of resources resulted in certain inter- and intrasectoral shifts in the budget structure, as compared with the PRSP targets. On one hand, the allocation to education within the total expenditure of the consolidated budget increased, and on the other hand the share of general education enlarged within the total expenditure in education.

Table 13. Consolidated Budget Expenditure for Education over 2003-2005

\begin{tabular}{|c|r|r|r|r|r|r|}
\hline & $\mathbf{2 0 0 3}$ & $\mathbf{2 0 0 4}$ & $\mathbf{2 0 0 5}$ & $\mathbf{2 0 0 3}$ & $\mathbf{2 0 0 4}$ & $\mathbf{2 0 0 5}$ \\
\cline { 2 - 6 } & \multicolumn{2}{|c|}{ PRSP } & \multicolumn{3}{|c|}{ Actual } & Budget \\
\hline Education total, billion drams & $\mathbf{3 5 . 2}$ & $\mathbf{4 2 . 8}$ & $\mathbf{5 2}$ & $\mathbf{3 5 . 4}$ & $\mathbf{4 8 . 4}$ & $\mathbf{6 3 . 6}$ \\
\hline Percent of GDP & 2.4 & 2.7 & 3 & 2.2 & 2.5 & 3 \\
\hline Percent of consolidated budget expenditure & 9.4 & 11.0 & 12.3 & 9.7 & 12.1 & 13 \\
\hline Percentage change, as compared with previous year & 18.3 & 21.6 & 21.4 & 19.1 & 36.7 & 31.4 \\
\hline $\begin{array}{l}\text { Elementary, basic, and secondary education, billion } \\
\text { drams }\end{array}$ & $\mathbf{2 3 . 0}$ & $\mathbf{3 0 . 2}$ & $\mathbf{3 7 . 5}$ & $\mathbf{2 3 . 2}$ & $\mathbf{3 4 . 4}$ & $\mathbf{4 5 . 3}$ \\
\hline Percent of GDP & 1.6 & 1.9 & 2.1 & 1.4 & 1.8 & 2.1 \\
\hline Percent of expenditure in education & 65.4 & 70.5 & 72.2 & 65.5 & 71.1 & 71.2 \\
\hline Percentage change, as compared with previous year & 23.2 & 31.0 & 24.2 & 23.4 & 48.3 & 31.7 \\
\hline
\end{tabular}

Source: National Statistical Service, Ministry of Finance and Economy, and PRSP projections.

139. The Government assumes that an important prerequisite to raise the quality of education is the persistent implementation of the policy of increasing teacher salaries in general education. The Government consistently implements the policy of salary increase, thus considering it to be a guarantee for growth of education quality. Particularly, the average monthly salaries were increased by 20 percent in 2003, 66.5 percent in 2004, and 65.3 percent in 2005, up to around 50.5 thousand drams. The ratio of teacher annual salaries to GDP in Armenia was 0.49 in 2003, 0.7 in 2004, and 1.0 in 2005 , depending on the educational level and the length of service, as compared with the respective OECD indicator ranging within 0.97-1.45. 
140.

Another priority of public expenditure in general education is to improve school facilities and to solve heating problems, so as to ensure the continuity of the educational process, and to enhance the enrollment. In 2004, large-scale construction and renovation works were implemented in general education. Under proceeds of the 8 billion dram budgetary allocation for civil works, 25 school buildings were constructed and 187 schools were capitally renovated. Through the co-financed programs of the Armenian Social Investment Fund, 16 school buildings were constructed and 148 schools were capitally renovated. The programs financed by the US-located Armenian Educational Establishment and the Armenian Benevolent Union for school renovation was continued. The number of renovated schools in Armenia has now reached around 100.

141.

In order to improve school heating, since 2003 the quantity of fuel provided for heating purposes and the number of heated days were increased, through differentiating schools by their location in plain, mountainous, and high-mountainous areas. Moreover, in 2005 additional allocations to fuel and heating were stipulated for arranging school heating through own boiler houses.

142. The efficiency of use of state allocations has bettered due to school optimization and increase of weekly workload of teachers. According to RA Government Decree No.444 dated April 25, 2002, to the end of efficient and purposeful use of budgetary allocations, in 2004 the transition of all general education schools to new financing and council management system was completed. According to experts' conclusions and research, the latter is far from full operation and has more official meaning so far26. This was determined by lack of awareness and information about new management system, and misunderstanding of functions. The Government has planned to initiate retraining programs for headmasters of 200 schools and 1200 council members through MTEF over 2006-2008. That will help develop the introduced system.

143. To enhance the education quality and provide compliance, the Government has carried out works aimed at raising the qualification of teachers and organizing short trainings. Around 10950 teachers were involved in training programs in the first six months of 2004-2005. Various seminars and group discussions were held. By the list of PRSP planned measures training of 35000 teachers was planned for 2004-2006. Training for compliance with the new education form will start in 2006. A map of educational

\footnotetext{
26 "Monitoring of School Expenditures and Operation in Shirak Marz, Republic of Armenia" Yerevan, 2004 Territorial Development Center, Transparency International Armenian Branch
} 
zones of training has been devised. 52 school-centers have been selected from those regions, and they will become a basis for implementation of training programs. 7 branches of National Institute of Education (NIE) were created in 2004 and currently 13 branches operate in all the marzes.

144. According to PRSP there is a need for improving the professional qualification of teachers and professional rating of teachers. Till 2003, from teachers employed in the general education system only $4-5 \%$ were trained, and in $2004-8-9 \%$ (it is projected to bring it close to $20 \%$ in 2005). It is sufficient for providing training for period of 5 years. The process of enhancing the qualification and training, and their relation to certification remains to be a serious and pending problem.

145. But according to experts' assessment the measures aimed at enhancing qualification and training of teachers are still not satisfactory. The teachers' optimization process without training, certifying and quality recognizing has created certain corruption risks too. Those risks are still happening in the teachers' "army"- by unjustified flow of employed teachers into pedagogical Higher Education Institutes (state or private, by correspondence, external or other forms of study). There is a need to study the relative "redundancy" of teachers, the current plan situation of educating teachers and the actual demand of education system- in the context of continued state mandate.

146. The Government pays close attention to filling the border, highland and mountainous areas of the country with teachers. To this end, 149 teachers were relocated to various marzes in the reporting year. Certain privileges were set for them. Among those teachers, 14 were students having switched to an individual schedule. Moreover, since 2004 special reception to Pedagogical University, Institute of Physical Training and Agricultural Academy was carried out, based on bids received from 6 marzes of the RA.

147. In cooperation with the Ministry of Labor and Social Affairs, social support programs for redundant teachers were elaborated and implemented, and 50 million drams were allocated to this end from the World Bank credit funds.

148. The Government took certain steps to ensure equality and universal availability of education. In particular, the policy of providing free textbooks to students of elementary classes was persistently pursued. 
149.

According to UNDP analysis27, the resources of revolving fund of textbooks operated within educational programs are gathered through mandatory payments for "lease" of textbooks by students of secondary schools, and these resources are used for updating, restoring and purchasing new books. RA Government allocates only $10 \%$ financing to this fund for socially vulnerable families. At that, the allocation distribution mechanism is extremely clear, and has no link with poverty. According to findings of statistical survey, school expenses per student totals average 2500 drams 28 , or in terms of annual expenses - more than 10 billion drams (without expenses of private classes). But for textbook lease related small "privileges", the load of all listed expenses are equally born by both poor and non poor families. While for the poor families these expenses mean regressive tax, they come to be a heavier load on poor families. Consequently, general education is not equally accessible for poor families.

150.

Provision of Preschool Education Quality and Accessibility: Preschool education is the primary unit of public education. This level of education was omitted from PRSP, but the list of measures of 2004-2006 attempted to fill this gap.

151. According to "Education in Armenia" annual book29, the number of preschool settings has dropped by $47 \%$ as compared to 1991 , and involvement of children - by $69 \%$. Low level of involvement of preschool aged children (5-6 years of age) is especially preoccupying, and it directly impacts the quality of general education 30 . The UNDP findings indicate that the lowest level of involvement was recorded in preschool institutions in Armenia31.

152. RA law "on Preschool Education" was adopted. It aims to regulate the legal, organizational and financing bases for operation and development of preschool education. Among the problems of regulation is the provision of involvement of children in preschool education and efficient management of the system. A National Program of Preschool Education Development and Piloting was approved in the reporting year.

\footnotetext{
27 "Human Poverty and Poverty Targeted Policy in Armenia" draft report, UNO, UNDP, 2005

${ }^{28}$ Social Overview and Poverty in Armenia, Statistical analytical report, RA NIS, Yerevan 2003

29

"Human Poverty and Poverty Targeted Policy in Armenia" draft report, UNO, UNDP, , 2005

30

RA Government has adopted "Concept Paper and Strategy of RA Preschool Education Development"

31

"Human Poverty and Poverty Targeted Policy in Armenia" draft report, UNO, UNDP, , 2005
} 
153.

Within collaboration with UNO Children Foundation pilot programs of parents' education and alternative services introduction was implemented in the sphere of preschool education in 2004. As a result of first stage of the latter 180 children were involved in extra services of preschool settings.

154. To improve the professional qualification of preschool teachers, training of 65 principals and 320 teachers of preschool settings was implemented in 2004. Exercise books and methodological manuals for children of 6 years of age were published.

155. According to experts' assessment, the problem of salary of preschool personnel is topical, and transition from policy of teachers' payment to the one directed at raise of salary of pedagogical personnel is a necessity.

156. RA law "on Preliminary professional and Secondary Professional Education and Training" was elaborated and approved by the RA National Assembly. RA Government has approved "the Strategy of Preliminary Professional and Secondary Professional Education and Training". The main goal of the strategy is to provide preparation of quality specialists compliant with demands of economy and labor market through creating a democratic and efficient system of elementary and secondary specialized education in Armenia. Developed were also the priorities of specialized education and teaching modernization and the activity plan for 2005-2006. Re-opening the vocational schools was a significant achievement in this regard. A state educational criterion for 10 specialties of secondary specialized education has been worked out and approved.

157. Exemplary teaching plans for preliminary specialized education has been introduced in vocational schools- for 19 specialties and specializations. As a result of structural improvements, a number of vocational schools have been reorganized into preliminary specialty teaching settings 32 - vocational schools, the number of which totals 26 today. There are 10980 students studying free of charge in these vocational schools. According to experts' analysis, reorganization of vocational schools was determined by demand of labor market and new public relations ${ }^{33}$.

158. The Government has paid attention to problems of developing specialists' potential. In particular, about 50 instructors were retrained for preliminary and

\footnotetext{
32 By RA Government Decree No.637 dated 22 May, 2003 the list of specialties of preliminary specialization education was approved. It includes 50 specialties of 229 qualifications.

33 Preliminary analysis of labor market- with emphasis on youth issues" report, Part A, page 53, “Avag Solutions" LTD, Yerevan 2004
} 
secondary specialty teaching institutions. Currently, around 2300 students study in vocational schools - 1980 students study free of charge, the rest - on paid basis. During 1-3 years they are taught the specialties of construction, agriculture, transportation, radio-electronics, food and household survey and other areas of 28 specialties. The graduates get certificates of craftsman (qualified worker or foreman), and students of main general education - those of secondary (full) general education.

159. Concurrently, with government spending increases, there are issues being dealt with that relates to the management and efficiency of the educational system. In 2003, according to the decentralization of management and the increasing of the institutions' autonomy, every school was redefined as a state non-commercial legal entity. According to the ratified schedule, by 2005 , it is planned to complete, in all schools, the activities related to their financing on a per student basis. The measures taken to raise the productivity of the system's activities aimed to establish the number of teachers, increase teacher workloads, and optimize the school network. As a result, there were positive changes in significant indicators defining productivity. These comply with PRPS considerations. In 2004, the student/teacher ration in general schools was 11.1, as opposed to 10.8 in 2003. The average class size was 22.2 pupils, instead of 16.2 in 2003. In tertiary education transition to two- level system and elaboration of tertiary specialties criteria became the most vital outcomes. Compliant with the criteria the curriculums of tertiary specialty subjects were reviewed. In 2004, RA law "on Tertiary and PostTertiary Specialty Education" was adopted. It triggered the enhancement of development, efficiency and quality of specialty education. Special reception was implemented for pedagogical, agricultural and physical training specialties. The list of specialties of extra-mural education was expanded.

\section{$\underline{\text { Infrastructures }}$}

\section{Water Economy}

160. From Poverty Reduction Strategy viewpoint, the RA Government has proclaimed the provision of population with accessible, affordable and quality services supply as the main objective of the policy implemented in the sector of water economy. Consequently, the RA Government has defined the frame of problems that demand a prioritized solution: enhancement of accessibility, affordability and quality of services, enhancement of better addressed subsidy policy, enhancement of efficiency of management of the system companies, improvement of calculation system.

161. The state budget expenditures in the sector of water economy amounted to 
about 22 billion drams in 2004, which is a little more than the financing volume of 21.6 billiard drams projected by PRSP for 2004. Compared to PRSP, 2004 state budget sector expenditures were structured in a little different configuration. Thus, 4.4 billiard drams was projected by PRSP for subsidy of system companies, while 6.9 billiard drams was projected by the state budget, 17.2 billion drams was projected by PRSP for investment programs, and, those expenditures equaled to 13.5 billion drams by the state budget. In this respect, the Government policy, as defined by PRSP, will be aimed at gradual reduction of subsidy volumes till the complete termination of subsidy, at the expense of increase of financial sustainability of system companies. In outcome, budgetary freed-up resources will channeled at implementation of better addressed social program.

162. As shown by findings of household survey carried out in 2004, progress has been registered with regard to drinking water affordability degree. In particular, in 2004 the affordability degree of centralized water supply increased by 0.5 percentage point, which was mostly due to rise of affordability degree of centralized water supply in rural areas by 0.6 percentage point (see the Table14).

Table 14. Affordability of Drinking Water

\begin{tabular}{|l|r|r|r|}
\hline & \multicolumn{1}{|c|}{2002} & \multicolumn{1}{|c|}{2003} & 2004 \\
\hline Affordability of Centralized Water Supply, percentage & 89.1 & 91.0 & 91.5 \\
\hline Urban areas, percentage & 97.0 & 97.8 & 96.7 \\
\hline Rural areas, percentage & 77.0 & 80.6 & 81.3 \\
\hline Number of households who use fetched water, percentage & 5.2 & 5.9 & 4.5 \\
\hline Source- household surveys of 2001, 2002, 2003.
\end{tabular}

163. Works were in progress during 2004, aimed at structural improvements in the system, introduction of irrigation and drinking water and water provision calculation systems, raise of water supply duration and improvement of quality, raise of efficiency of collection of payments for supplied water, decrease of loss in the system and raise of efficiency of companies, gradual reduction of electricity expenditure through gradual replacement of mechanical irrigation and drinking water supply by gravity flow, installation of measuring devices, efficient use of credit resources, etc.

164. The increase of affordability degree of centralized water supply in rural areas during the period of 2003-2004 could mostly be determined by a range of implemented investment projects. In particular, in more than 40 rural areas water supply systems were either rehabilitated or constructed in that period, an outcome of programs implemented by German Rehabilitation Credit Institute(Kreditanstalt fir Wiederaufbau- KfW), International Foundation of Agricultural Development (IFAD), USA Department of 
Agriculture and Armenian Social Investment Fund.

165. Progress has been registered also with regard to decreasing the share of households who use fetched water. As shown in the Table14, share of households who use fetched water dropped by 1.3 percentage point and made 4.6 percent, the main part of which is centralized in rural areas. In this regard, the Government intends to continue the policy of solving the given problem through implementation of investment programs in individual areas. And in those areas where the construction of water supply will not prove economically effective, RA Government will aim its policy at reimbursement of population's water related extra expenditures. Respective amendments may be made in PRSP in the process of the upcoming review.

166. One of the most important investment policies implemented in the sector of water economy, as defined in PRSP, is the change of energy structures in the system of service supply. To this end, within the World Bank project of "Irrigation Systems Development" construction works of three gravity systems were carried out. In the outcome of operation of three gravity systems, annually about 48 million $\mathrm{kW} / \mathrm{h}$ energy will be saved, which makes about 20 percent of energy consumption in this sector.

167. In the reporting period an essential progress was registered in the water economy directed at improvement and upgrade of the calculation system, which was also another significant direction of implemented investment policy. In order to improve and upgrade the calculation system, serious measures were implemented in the areas supplied by Yerevan "Water and Wastewater" CJSC “Armenian Water and Sanitation Company" CJSC, as well as by "Nor Akunk" CJSC. During 2004 more than 85 percent of subscribers in the area supplied by Yerevan "Water and Wastewater" CJSC installed individual water meters; the number of subscribers who installed individual water meters in the area supplied by "Armenian Water and Sanitation Company" CJSC reached about 120 thousand; and in the area supplied by "Nor Akunk"- about 10 thousand. At that, during 2004 the budgetary resources were used by Yerevan "Water and Wastewater" CJSC to install 31361 water meters in apartments of families involved in the family poverty benefit system.

168. According to PRSP, the tariff policy of water economy and that of public services in general should be directed at adjustment of tariffs to exploitation expenses. Toward this end, in 2004 and 2005 the irrigation and drinking water tariffs were reviewed. The drinking water tariffs were reviewed by Armenia's Public Services Regulatory Commission in April, 2004 and May, 2005.Currently the drinking water 
tariffs make 125 drams per $1 \mathrm{~m} 3$ in the area supplied by "Water and Wastewater" CJSC, and 140 drams-respectively in the area supplied by "Armenian Water and Sanitation Company" CJSC. Eight tariffs were identified for four branches of "Irrigation Water" CJSC divided by principle of water reservoir. In 2004 the average tariff of $1 \mathrm{~m} 3$ irrigation water made 6.8 drams. Despite the rise in tariffs, the latter remain to be low to cover expenses, and in this regard, in the upcoming period the tariff policy will be directed at ensuring the adjustment of tariffs and exploitation and maintenance expenses.

\section{Road Construction}

169. In accordance with PRSP, the expenditures directed at road construction through internal resources of state budget increased significantly. Thus, in 2003 the actual expenditures (without loan and grant programs) of state budget in the sector of road construction amounted to 1.3 billion drams, and in 2004 the expenditures channeled into road construction through state budget amounted to about 7.3 billiard drams, 5.6 times more than in 2003.

170. At that, in 2004 the state budget for the first time financed the works of reconstruction and current maintenance of roads considered to be of community significance by PRSP prioritization - about 570 million drams, which makes about 8 percent of resources allocated through state budget.

171. Within the road component of the WB Transport Credit Project in 2004 reconstruction works of $88 \mathrm{~km}$ of roads of interstate and republic significance were implemented compliant to international standards, amounting to 5.4 billion drams.

\section{Energy}

172. Activities of energy sector were mainly directed at satisfying the energy demand of the republic, maintaining at least the current level of energy independence, including by diversification of imported (natural gas, nuclear fuel, mazut- as strategic reserve) and local energy reserve (hydro, wind, solar and others) and by maximum use of production capacities.

173. In accordance with PRSP the main directions of investments made by the Government in the sector of energy are rehabilitation and development of electricity transmission and regulation, as well as financial rehabilitation of the system. With this end in view, respective works were accomplished by the Government in the reporting period.

174. In particular, in 2004 with support of German KfW works of rehabilitation of Kanaker Hydro Power Plant and Electricity Transmission sector were implemented 
amounting to about 1.15 billion drams. And within the WB Program on Rehabilitation of Electricity Transmission lines and Distribution Networks works amounting to 7.8 billion drams were implemented.

175. To ensure financial rehabilitation of the system the Government used about US \$27.0 million dollars from proceeds received from privatization of "Zangezour CopperMolybdenum Industrial Complex" CJSC to fully pay off the old bad debt of energy of population recorded in "ArmGas" CJSC. About US \$4.8 million dollars of the received resources were used for co-financing of Iran-Armenia gas pipeline, and US \$22.2 million dollars were used to pay off the system loan obligations, which essentially decreased the size of loan portfolio of the system's companies.

176. State budget expenditures in the energy system34 amounted to about 9.136 billion drams in 2004. According to PRSP, one of the main directions of investments of the Government made in energy sector is rehabilitation and development of electricity distribution and regulation. Respective measures were taken by the Government in the reporting year.

177. Official data state that 80 posts, as well as around $1250 \mathrm{~m}$ of cable of new communication lines of "Energy Communication" branch of "Electricity System Operator" CJSC were replaced. It was a measure towards modernizing and developing the equipment of the system of electricity regulation.

178. During 2004 electricity of 6030.0 million KWT/H was produced in the republic, as compared to that of $529.1 \mathrm{KWT} / \mathrm{H}$ of previous year, of which 338.8 million KWT/H or $5.6 \%$ was used by producing stations for own needs.

179. Despite the generally poor situation existing in the electric pover transmission network and insufficient modernization activites, $83 \%$ of the rural population is satisfied with the quality of the electric power provision, out of which around $40 \%$ believes that the electric power provision is pleasing.

180. Findings of household survey carried out in 2004 show that about 5.5 percent of urban households did not heat their houses in winter. And the frequency of diseases happening to people who have no heating in households in winter is twice more than the average level in the country. At that the share of poor households with no heating is

\footnotetext{
34 More detailed information about financing done in energy sector see appendix 14.1
} 
twice higher35, which is a proof that the main reason for not heating the houses is its non-affordability for poor families. Arising from the mentioned situation, the Government will pay a special attention to heating problems, especially in urban areas, during the upcoming PRSP update.

\section{$\underline{\text { Agriculture }}$}

181.

The gross agricultural product in 2004, as compared with the 2003 level, increased by around 14.5 percent. The same growth dynamics were served during the first six months of 2005; the increase over the respective period of the previous year amounted to 10.2 percent.

Table 13: Dynamics of Gross Agricultural Product over 2001 - 2004 and of first six months of 2005

\begin{tabular}{|c|c|c|c|c|c|}
\hline & 2001 & 2002 & 2003 & 2004 & $\begin{array}{l}2005 \\
\text { First Half }\end{array}$ \\
\hline Gross agricultural product, billion drams & 351.0 & 377.6 & 410.1 & 504.1 & 103.6 \\
\hline $\begin{array}{l}\text { Gross agricultural product, percentage change as compared } \\
\text { with previous year }\end{array}$ & 11.6 & 4.4 & 4.3 & 14.5 & 10.2 \\
\hline Of which :Horticulture, percent & 19.0 & 4.6 & 4.4 & 20.1 & - \\
\hline Livestock breeding, percent & 2.3 & 4.2 & 4.3 & 8.0 & \\
\hline
\end{tabular}

Source: National Statistical Service.

182. As shown by the results of the 2004 household survey, rural poverty decreased by 6.8 percentage points, as compared with 2003 . At that, cash income of the rural population over the same period increased by around 11.0 percent.

183. In the meantime, the level of rural poverty remains higher than that of urban poverty. In 2004, these indicators comprised 40.7 percent and 38.0 percent, respectively. The latter may first of all reflect the fact that per capita cash income in rural areas is around 33.0 percent lower than that in urban areas.

184. Revenues from hired work in rural areas also remain at a low level. In 2004, their share within the total cash income was only 27.9 percent, whereas in urban areas the same indicator was 56.8 percent. This means that in rural areas, the problem of developing non-agricultural activities has not been dealt with yet, and the government policy will aim at introducing efficient mechanisms, as well as developing infrastructures for stimulating non-agricultural employment in rural areas.

185. In 2004, the agricultural product price index comprised 109.6 percent, and the consumer price index 107.0 percent, as compared with the 2003 level. The overtaking

35 "Human Poverty and Poverty Targeted Policy in Armenia" draft report, UNO, UNDP, , 2005 
increase in the prices of agricultural products could possibly explain why cash income in rural areas has shown a faster growth rate (11.0 percent), than that in urban areas (5.4 percent), but per capita revenues in rural areas by absolute value were less than those in urban areas

Individual Measures Implemented in Agriculture Sector within PRSP and the Received Outcomes

186. In 2004 the grain production increased by $47.2 \%$, potato production- by $13.6 \%$, vegetables- by $5.5 \%$, fruit- $10.2 \%$ and grapes - by $82.5 \%$. According to official data, 146.9 thousand tons increase of grain gross crops was determined by productivity enhancement at $88.5 \%$ and of added sown area of grain at $11.5 \%$. The increase of 31.3 tons of vegetables was determined by intensive factor of increased productivity. With regard to grapes production increase ( 67.3 thousand tones), about $73 \%$ of it was also determined by enhanced productivity.

187. According to official data, measures implemented in the area of plants protection within PRSP considerably helped the unprecedented productivity of grain harvest, as well as enhanced productivity of other cultivated plants. Those measures will be continued. The anticipated outcome is to eliminate infectiousness of grasshoppers (by $100 \%$ ) until 2007, and reduce the number of mouse-like rodents by $70 \%$ compared to 2004. As a result, in 2007 the damage caused to plant cultivation by harmful organisms is expected to be decreased by $60-80 \%$.

188. During the reporting year, measures taken in seed production also helped enhance the productivity of agricultural plants. However, there exist certain problems in the seed production. A qualitative research was carried out in this area. It revealed that the main part of land-cultivators do not trust the local and imported cultivars purchased from seed producers and seed stations, those are considered to be of low productivity 36. Presumably, the law "on Seeds", adopted by National Assembly in May, 2005 will regulate the seed production, exchange and use relations.

189.

In order to elaborate the scientifically proven agricultural soil fertilization systems, agro-chemical field research were carried out in 137 communities of the country in 2004 over 41165 ha area. As a result, "correct systems of soil fertilization"

\footnotetext{
36 Armenian Rural Enterprise and Agricultural Small Commercial Development Program, "Hazarashen” Armenain Ethnological Research Center, Yerevan, March 2005. The research was carried out in four marzes of Armenia- Armavir, Shirak, Lori and Syunik-19 rural areas and three marz centers. It was done by qualitative research method - in-depth interviews with farmers, entrepreneurs; expertise interviews with heads of villages or their deputies, commercial farmers, veterinaries, rural owners, marzpetaran officials and marz companies, unions assisting farms activities and entrepreneurship and NGOs. Overall, 176 interviews were held, 9 focus groups discussions were held three in each of Armavir, Lori and Syunik marzes.
} 
instructions and agro-chemical maps were devised and provided to communities. As a result of on-going implementation of this measure, it is expected that in $200740 \%$ of land-users will apply the soil quality improvement and protection methods proposed by Ministry of Agriculture. It is projected that starting from 2005 this measure will be gradually implemented at the expense of beneficiaries.

190. It should be mentioned that research was carried out in Armavir, Shirak, Lori and Syunik. It indicated that the main fertilizer used in these marzes is nitric fertilizer, even when other fertilizer is needed for sown areas. The main reason is, first of all, today this is the fertilizer offered for a better price to land-users. The research showed that the land-users are discontent with quality of nitric fertilizer imported from Georgia, they claim that it does not contain enough nitrogen37. Thus, potassium and phosphorous fertilizers required by agro-technical regulations are not used by agricultural farms today, and the ratio of the used organic fertilizers is very low.

191. For a country with natural-climatic conditions like Armenia it is of utmost importance to restore anti-hail service. The respective works are still in initial condition. Presently, 15 anti-hail stations are located in Aragatsotn marz, and they are in piloting process.

192. In 2004, the volume of main livestock products has increased too - meat production - by $2.8 \%$, milk production $-8.1 \%$, eggs- $12.1 \%$ and wool $-1.7 \%$. According to government assessment, $57.4 \%$ of increase of 41.5 thousand tons of milk was determined by increase of heads, and $42.6 \%$ - by intensive factor of milk production. As to increase of 60.8 million items of eggs, it was determined by laying hen heads at $70 \%$, and by increase of egg laying at $30 \%$.

193. Preventive immunization vaccinations of agricultural animals against 5 infectious diseases made within anti-epidemic vaccinations program through state resources helped to enhance the productivity level of agricultural animals. In general terms, 6535 thousand vaccinations were made throughout the country, and as a result, no infection epidemic burst-outs were registered. These measures will be continued. It is planned that by the end of 2007 the degree of anthrax infection among agricultural animals will be dropped to $0.001 \%$ and that of brucellosis, tuberculosis pig typhoid- to $0.2 \%$. It is planned to drop the infection rate of $\mathrm{A}, \mathrm{O}$ and Asia-1 erysipelas disease to $0.5 \%$, as well as drop the infection rate of livestock cracking sprouts to $0.1 \%$.

\footnotetext{
${ }^{37}$ Armenian Rural Enterprise and Agricultural Small Commercial Development Program
} 
194. Productivity growth of agricultural animals was stipulated also by mid term program of "Artificial Insemination Measures". Around 23 thousand cows were inseminated within the program. In total about 25 thousand cows were inseminated in 2004. It is planned to increase the insemination volume on a yearly basis, and as a result of the program, raise the milk productivity by $15-20 \%$ through artificial insemination. For the same objective, draft law "on pedigree livestock breeding” has been developed, which currently is in National Assembly for discussion. In the meantime, a program of "Maintaining Caucasian dark beef gene pool" and currently, the Government is initiating measures to finance the program.

195. Consequently, the research indicates that, the livestock have lost qualitative characteristics caused by loss of breed, poor care, and poor feeding. Although the services of artificial insemination are being restored, however, for rather a long period no artificial insemination was done. In 2004, from among 3.400 cows only 800-1000 were artificially inseminated. A big part of the used sperms were left since soviet period through deeply freezing method, and the quality has diminished. RA draft law "on Pedigree Breeding” was worked out by the Ministry of Agriculture in the reporting year. After the pedigree breeding farm of Lori was destroyed, no quality sperm has been stocked in Armenia. According to the research, the pedigree of Caucasian dark beef, best for Armenian climate, has almost disappeared in Armenia.

196. To prevent the soil water level decrease and secondary salinity, a program of collector-drainage network cleaning and repairing was implemented. Within the program cleaning and repair works of $367.8 \mathrm{~km}$ length networks were implemented mainly in Ararat and Armavir, and, at some extent in Lori, marz too. As a result, the melioration of 8.5 thousand ha irrigated agricultural land has bettered and sanitary-hygienic conditions of 39 communities have improved. It should be mentioned that the measure of salinity withdrawal of irrigated water of Ararat valley was not conducted because of lack of finance. It is planned to be launched in 2005.

197. A number of measures are planned within PRSP aimed at enhancing soil use efficiency, reducing the number of land plots, formulating land market, facilitating investments and hypothetic crediting in agricultural land. Within those measures from total 508184.5 ha of stately owned land 306612.2 ha were provided to 318 communities with the right of ownership for free.

198. This process brings to merge of land, and that will help to enhance the land market efficiency thus facilitating the formation of more vigorous agricultural farms. 
This scenario is quite applicable for Armenia both for mid and long term perspective. But in near future, it will deepen the poverty and extreme poverty, and eventually the land will be mobilized in hands of few groups, and will bring to further impoverishment of already poor small land owner. In the meantime, sale of pastures will lead to further worsening 38 of condition of poor farmers who breed livestock. Special attention and extra efforts need to be directed at soil amalgamation and land market formation processes to reveal their poverty-targeted direction.

199. Soil amalgamation will also lead to formation of cooperatives, associations, companies and other unions. That process will be facilitated by adoption of RA law "on Agricultural organizations and cooperatives". In the meantime, certain size of land plots might be given to residents of town-type areas from land plots granted to communities; that will become a poverty reduction means39.

200. It should be mentioned that the preventive measure for negative consequences of land amalgamation is postponed because of lack of financial resources. That preventive measure would be determining of optimal size of agricultural farms in low and pre-mountainous areas and creation of pilot cooperatives in three marzes to specify the efficient watering techniques and implementation of measures for their operation.

201. To the end of updating and filling the agricultural machinery of the country, 53 grain-collecting combines and 226 tractors were imported at expense of Japan Government. For the same objective 51 units of tractors and agricultural tools and spare parts were imported within a charity program of China. The imported machinery was either sold in auction or leased.

202. However, there is a lack of machinery in rural communities today. The technological part of the country is being restored by $0.5-0.6 \%$ annually and mainly with foreign support, while the restoration should be done by $7 \%$ annually. There is a shortage of agricultural machinery of small (medium) capacity, also the functioning level is poor, agricultural tool production is not organized on basis of current capacity of industrial enterprises, the leasing ratio is low, cooperation processes of agricultural machinery use are also slow, etc. Since the farmers do not come into cooperation, practically the machines are operated individually for each of them, and thus it becomes

\footnotetext{
${ }^{38}$ Max Spur, Land Reforms, rural poverty and unequality: poverty targeted approaches of land policy, UNDP Program, Yerevan, December 2004

${ }^{39}$ Protocol of Session of PRSP Agriculture Measures, Ministry of Finance and Economy, Yerevan, June 3, 2005
} 
$-54-$

a rather costly work for cut land plots especially in highland, rough soil conditions 40 .

203. Since 1998 Program of Agricultural Loan Clubs is continued, with objective of supporting agricultural and farm companies through financial and technical assistance. This program is a financial assistance component of US Department of Agriculture (USDA) Marketing Assistance Program and it aims to solve the agriculture problems in formulating agricultural food cooperation. With regard to formulating cooperation in the aspect of agricultural food, it is noteworthy, that legal field creates unequal conditions for infrastructural units of diverse organizational forms. Founding organizations for provision of services on cooperation principle immediately brings to levy of value added tax and profit tax, which is mainly evaded by private owners 41 who carry out similar operations.

204. To stabilize the socio-economic condition of mountainous, remote and more vulnerable villages, in 2004 a program of agricultural services was implemented through resources of International Foundation of Agricultural Development (IFAD). Within the frames of the program peach orchard of 24 ha was planted in Tavush marz and various orchards of 57 ha were planted in Syunik marz. Also in the area of irrigation support was allocated to 23 Water User Associations, the total irrigation area of which totals 73.8 thousand ha. Construction works related to irrigation water provision were implemented in 29 spots. As a result, water provision was enhanced in about 15 thousand ha land plots. Rehabilitation works of Voskevan-Barekamavan inter-village (Tavush marz) road of $18.1 \mathrm{~km}$ in were completed.

205. In general outline, in the reporting year agricultural loan volume by banking system amounted to 8.611 billion drams, and the agricultural crediting percent against agriculture added value totaled $1.7 \%$. PRSP projected that in case of $2.8 \%$ increase of agriculture added value in 2004 the percent of agriculture crediting would amount to $3.4 \%$ or 11.90 billion drams. Interest rate of credits allocated to agriculture floats within $18-22 \%$ range, which is rather high when compared with yield percentage.

206. To enhance the demand of agricultural economic entities for loan resources and operation efficiency of agrarian scientific-educational system, the Program of Agricultural Reforms Support was carried out. Within the program in the course of 2004

\footnotetext{
${ }^{40}$ Protocol of Session of PRSP Agriculture Measures

${ }^{41}$ Hrachya Tspnetsyan, Development of Agricultural Production Infrastructures, as an important direction to poverty reduction, Rural Poverty in RA marzes
} 
around 2068 short term credits, amounting to US 2192.9 thousand dollars were allocated through WB resources. In the meantime various consulting services were rendered, multiple seminars and marketing intermediations were held, as well as radio-programs were cast by 10 Agricultural supporting marz centers. However, it is worth to record that there exists a problem of awareness about consultative programs in rural areas. Small groups of commercial farmers and veterinarians have emerged in villages; their activities are still in their first stages 42.

207. In terms of agriculture development Poverty Reduction Strategy signifies the task of establishing a functioning system of agricultural activities insurance. However, the agricultural insurance risk assessment program has not been carried out so far because of lack of finance. In order to develop insurance sphere, the Ministry of Agriculture has elaborated a respective concept paper. At present, it is crucial to implement an agricultural insurance risk assessment, as well as specify the size of Government assistance to be directed at development of a given aspect. Currently it would be expedient to implement the agricultural insurance risk assessment in the upcoming period - after finding other sources of finance besides the RA state budget.

208. In terms of agriculture Poverty Reduction strategy signifies the tasks of establishing functioning system of seasonality and market protection. No measures were planned by 2004 PRSP. By proposal of Non Governmental Sector this problem will be tackled during the upcoming PRSP review.

209. Sustainable development of agriculture is necessary for efficient reduction of material poverty. That must be the most important from the point of view of providing the sufficient level of food independence, as food independence (basic level of food sufficiency) is the main precondition for prevention of food crisis during possible extraordinary situations. It is considered to be one of the most important components of national security.

\section{Nature Protection}

210. From the viewpoint of impacting the poverty of rural and urban population, nature protection problems are shown in different ways. That impact over rural population is mostly determined by their strict dependence on national resources. In this respect, the problem of degrading leaves an immediate impact over the income level of rural population. Also air pollution, illegal construction in parks and destruction of green

\footnotetext{
${ }^{42}$ Armenian Rural Enterprise and Agricultural Small Commercial Development Program
} 
$-56-$

zones also mean intervened influence over the urban population's living conditions. The urban poor population, as a rule, lives mainly in the most unfavorable zones from the environmental standpoint - in neighborhood of industrial enterprises, waste-piling zones.

211. From standpoint of poverty reduction strategy, nature protection and environmental tasks may be classified as follows:

1. effective management of forest resources

2. prevention of soil degradation, reduction of deforesting-conducive anthropogenic factors

3. effective management and use of water resources, and return of ecological balance of the lake Sevan

4. household waste removal and industrial harmful waste problems.

\section{Forest Resources Management}

212. To strengthen the forest resources management system, RA Ministry of Nature Protection has designed and the Government has approved the document of RA National Forest Policy and Strategy and the Illegal Logging Action Plan, as well as RA Draft of New Forest Code. In the meantime the design works of Armenian Forests National Program are in progress.

213. Despite the development and adoption of four documents of national importance listed in clause 210 that are aimed at effective management of forest resources, according to opinion expressed by public, as a consequence of illegal logging of dense forest neighboring Aghavnadzor, Marmarik, Meghradzor villages in Kotayk marz, some shrubs are left in expansive area. And soon the soil of deforested area will start to degrade and become a desert. In Yerevan city the construction of especially multi-storied buildings and often at expense of green zones, deteriorates the ecological condition of the city and raises the seismic risk. Such constructions infringe upon the ecological and social rights of residents, and distort the historical-cultural face of the city.

214. To provide sustainable forest management and use, to list and inventory forests, to create and implement a monitoring system of forests in Tavush and Gegharkunik marzes, forest management action plans of Ijevan and Sevkar forest enterprises (covering an area of around 45,000 ha) were implemented by "Hayantar" state non commercial organization, within the frames of Natural Resources Management and Poverty Reduction Program (NRMPRP).

215. However, according to NGOs and expertise groups involved in nature 
protection, the forest resources use and forest rehabilitation processes need of more detailed study, to help assess the accuracy of statistical data presented by state bodies.

$\underline{\text { Rehabilitation of Lake Sevan Ecosystem }}$

216. To rehabilitate and maintain the lake Sevan ecosystem the amount of water released for irrigation was calculated, and in 2004 it made 148.8 million cubic meters. The lake level of December 31, 2004 made 1897.65 meters and the level rise for the course of past two years made $133 \mathrm{~cm}$.

217. To rehabilitate and maintain the lake Sevan ecosystem the amount of water released for irrigation was calculated, and in 2005 it made 145.1 million cubic meters. The lake level of December 31, 2005 made 1898.06 meters, which it corresponds to level of the lake in 1991. In the course of last four years the rise of level made $174 \mathrm{~cm}$. Once again it proves about the steady tendency for rise of the lake's water level.

218. The steady tendency for the Lake Sevan water rise is assessed as positive; however, it is important to study possible impact of that tendency over the quality of the Sevan water.

Harmful Industrial Waste

219. In the area of managing harmful materials and waste, a number of vital regulating acts were devised and adopted in the reporting period, including: RA Law on Wastes, RA List of Harmful Wastes, RA List of Banned Harmful Wastes, National Outline of Chemical Materials and Wastes Management (the profile) and the list of measures to be implemented over 2005-2010 from Stockholm Convention National Action Plan "On Stable Organic Polluters in RA".

$\underline{\text { Rehabilitation and Development of Physical Infrastructures }}$

220. To establish effective heating supply and to promote accessibility, the voluminous project paper of "Improving the Energy Efficiency of Urban Heating and Hot Water Supply in Armenia" in the amount of US 2.95 million dollars was approved by the Government within the program of "Fighting the Obstacles of Energy Efficiency of Urban Heating and Hot Water Supply in Armenia. The program was launched in 2005 and will be financed by Global Ecological Fund. The program is targeted at greenhouse gas reduction.

Strengthening the Legal Framework Regulating Nature Protection and Nature

221. To regulate the sphere of Nature Protection and Use, RA Law "on Nature Protection Monitoring" has been adopted. It opens a new page in recorded policies 
implemented for environment maintenance in Armenia. Enforcement of RA Law "on Nature Protection Monitoring”, paralleled with technical strengthening of nature protection inspectorate system and drastic enhancement of professional skills of inspectorate personnel, will promote appropriate control over performance of norms and requirements endorsed by nature protection legislation. Thus, it will help prevent violations of nature protection legislation, and also will be in harmony with measures of strategic importance implemented in Armenia over the last 2-3 years targeting enforcement and expansion of legislation on nature protection and natural resources use.

222. Adoption of RA Law “on Compensation Tariffs for Damage Caused to Fauna and Flora through Nature Protection Legislative Violations", as well as approval of norms for assessing economic activities impact over water resources, land resources and atmosphere help the nature protection inspectorate bodies to provide better calculation and compensation of environmental damage.

223. To strengthen the legislative framework of nature protection and nature use, as well as to optimize the payment types of that field, RA Ministry of Nature Protection has designed and presented to Government approval the draft law "on Payment Rates for Nature Reserves Use".

224. A number of amendments and additions made in RA law "on Payments for Nature Protection and Nature Resources Use" and the respective by-laws have made the system of payments more effective both for fiscal and regulating (lowering the volume of harmful emissions into environment) roles. Owing to the aforementioned, as well as through increased calculation of nature use and enhancement of nature protection inspectorate's efficiency, there is a substantial increase in on-going flow of nature protection and nature use payments into the state budget (compared to 1998 it has increased for 8 times). That allows to gradually raising the financial subsidies allocated through state budget for implementation of respective nature protection measures.

Besides:

- Since 2005 respective guarantee amounts have been accumulated in the environmental fund based on license contracts of mineral wealth resource use (in RA Central Bank special account). Those amounts will be used exclusively for recultivation, leveling, planting of trees and gardens and construction works. As of December 31, 2005 more than 58.3 million drams have been collected.

- By RA Government Decree No.897-N dated June 23, 2005 extra-budgetary account of "Nature Protection Target Fund" was established. According to 2005 outcomes, through volunteer payments, grants and donations with total amount of 37.8 million drams were given by legal entities and physical persons. In the reporting year a number of vital nature protection projects and measures were 


$$
\text { - } 59 \text { - }
$$

carried out through the allocated 17.35 million drams.

225. Adoption of RA law "on Making Amendments and Additions in RA Law on Atmosphere Protection" has enabled to introduce a respective system of controlling vehicle emissions polluting the atmosphere since January 1, 2006.

226. Owing to enhanced works of Nature Protection Inspectorate, the state budget entries of payments for natural resources use amounted to 1649.3 million drams increased for $40 \%$ compared to 2003. 
- 60 -

\section{Budgetary Framework and State Expenditure Policy - 2004 Developments and 2005}

\section{Budgetary Program}

227.

The 2004 annual budget is in essence the first budget which is fully based on the PRSP ideology and was programmed accepting the priorities set up in the PRSP. Under the 2004 budget the authorities put the target to ensure the increase of the state budget expenditures (in particular in the social sector and the infrastructures), mainly by a reasonable expansion of the budget resource package through improving tax administration and at the expense of foreign grants. At the same time, the Government pursued the policy of keeping the budget balance within the acceptable limits.

228. Revenues of the 2004 consolidated budget grew by $5.6 \%$ as compared with 349 billion drams of the previous year and totaled 368.6 billion drams. The growth of revenues was mainly driven by the growth of the domestic revenues, in particular, tax revenues (including duties) grew by around $16.7 \%$ in nominal terms, while non-tax revenues grew by around $60 \%$. The growth was fostered both by the improvement of tax and customs administration, and a more favorable macroeconomic environment than envisaged under the program. As for grants, during 2004 they drop by 3.7 times as compared with the previous year, because of the end of the grant projects implemented by the Lincy Fund during 2003.

Table 16. 2002-2005 Consolidated Budget Framework (on an accrued basis)

\begin{tabular}{|c|r|r|r|r|r|r|r|r|}
\hline & $\mathbf{2 0 0 2}$ & \multicolumn{2}{|c|}{$\mathbf{2 0 0 3}$} & \multicolumn{2}{|c|}{$\mathbf{2 0 0 4}$} & \multicolumn{2}{|c|}{$\mathbf{2 0 0 5}$} \\
\cline { 2 - 8 } & Actual & PRSP & Actual & PRSP & Actual & PRSP & Budget \\
\hline & \multicolumn{5}{|c|}{ Dram billion } \\
\hline 1. Total revenues and grants & $\mathbf{3 0 5 . 6}$ & $\mathbf{3 3 9 . 9}$ & $\mathbf{3 4 8 . 9}$ & $\mathbf{3 4 6 . 2}$ & $\mathbf{3 6 8 . 6}$ & $\mathbf{3 8 3 . 0}$ & $\mathbf{4 3 6 . 4}$ \\
\hline Total revenues & 258.1 & 279 & 297.4 & 312.9 & 354.8 & 349.6 & 424.3 \\
\hline Tax revenues & 242.3 & 269.4 & 279.3 & 302.2 & 326.1 & 338.8 & 389.7 \\
\hline Non-tax and capital revenues & 15.7 & 9.6 & 18 & 10.7 & 28.7 & 10.1 & 34.6 \\
\hline Grants & 47.5 & 61 & 51.5 & 33.3 & 13.7 & 33.4 & 12.1 \\
\hline Current & 17.1 & 14.1 & 11.6 & 9.7 & 13.7 & 9.0 & 12.1 \\
\hline Capital & 30.5 & 46.9 & 39.9 & 23.7 & 0.0 & 24.4 & 0.1 \\
\hline 2. Deficit financing (net) & $\mathbf{1 2 . 1}$ & $\mathbf{3 6 . 5}$ & $\mathbf{1 4 . 4}$ & $\mathbf{4 1 . 9}$ & $\mathbf{3 1 . 2}$ & $\mathbf{3 9 . 2}$ & $\mathbf{5 1 . 3}$ \\
\hline Domestic sources & -24.7 & 46.4 & -24.4 & 2.7 & -3.1 & 3.6 & 16.6 \\
\hline Foreign sources & 36.7 & -9.9 & 38.8 & 39.2 & 34.3 & 35.6 & 34.7 \\
\hline 3. Total managed resources (1+2) & $\mathbf{3 1 7 . 7}$ & $\mathbf{3 7 6 . 5}$ & $\mathbf{3 6 3 . 3}$ & $\mathbf{3 8 8 . 1}$ & $\mathbf{3 9 9 . 8}$ & $\mathbf{4 2 2 . 2}$ & $\mathbf{4 8 7 . 7}$ \\
\hline 4. Total expenditures and net lending & $\mathbf{3 1 7 . 7}$ & $\mathbf{3 7 6 . 5}$ & $\mathbf{3 6 3 . 3}$ & $\mathbf{3 8 8 . 1}$ & $\mathbf{3 9 9 . 8}$ & $\mathbf{4 2 2 . 2}$ & $\mathbf{4 8 7 . 7}$ \\
\hline Current expenditures & 243.5 & 279 & 271.5 & 294 & 323.9 & 335.6 & 380.4 \\
\hline Capital expenditures & 63.8 & 101 & 85.2 & 86.9 & 65.4 & 78.5 & 97.2 \\
\hline o/w: from capital grants & 30.5 & 46.9 & 39.9 & 23.7 & - & 24.4 & 0.1 \\
\hline Net lending & 10.4 & -3.5 & 6.6 & 7.2 & 10.5 & 8.2 & 10.1 \\
\hline
\end{tabular}




\begin{tabular}{|c|r|r|r|r|r|r|r|}
\cline { 2 - 7 } & \multicolumn{7}{|c|}{ In\% to $G D P$} \\
\hline 1. Total revenues and grants & $\mathbf{2 2 . 4}$ & $\mathbf{2 3 . 1}$ & $\mathbf{2 1 . 5}$ & $\mathbf{2 1 . 5}$ & $\mathbf{1 9 . 4}$ & $\mathbf{2 1 . 8}$ & $\mathbf{2 0 . 7}$ \\
\hline Total revenues & 18.9 & 18.9 & 18.3 & 19.4 & 18.7 & 19.9 & 20.1 \\
\hline Tax revenues & 17.8 & 18.3 & 17.2 & 18.8 & 17.2 & 19.3 & 18.5 \\
\hline Non-tax and capital revenues & 1.2 & 0.7 & 1.1 & 0.7 & 1.5 & 0.6 & 1.6 \\
\hline Grants & 3.5 & 4.1 & 3.2 & 2.1 & 0.7 & 1.9 & 0.6 \\
\hline Current & 1.3 & 1 & 0.7 & 0.6 & 0.7 & 0.5 & 0.6 \\
\hline Capital & 2.2 & 3.2 & 2.5 & 1.5 & 0.0 & 1.4 & 0.0 \\
\hline 2. Deficit financing (net) & $\mathbf{0 . 9}$ & $\mathbf{2 . 5}$ & $\mathbf{0 . 9}$ & $\mathbf{2 . 6}$ & $\mathbf{1 . 6}$ & $\mathbf{2 . 2}$ & $\mathbf{2 . 4}$ \\
\hline Domestic sources & -1.8 & 3.2 & -1.5 & 0.2 & -0.2 & 0.2 & 0.8 \\
\hline Foreign sources & 2.7 & -0.7 & 2.4 & 2.4 & 1.8 & 2.0 & 1.6 \\
\hline 3. total managed resources (1+2) & $\mathbf{2 3 . 3}$ & $\mathbf{2 5 . 5}$ & $\mathbf{2 2 . 4}$ & $\mathbf{2 4 . 1}$ & $\mathbf{2 1 . 1}$ & $\mathbf{2 4 . 0}$ & $\mathbf{2 3 . 1}$ \\
\hline 4. Total expenditures and net lending & $\mathbf{2 3 . 3}$ & $\mathbf{2 5 . 5}$ & $\mathbf{2 2 . 4}$ & $\mathbf{2 4 . 1}$ & $\mathbf{2 1 . 1}$ & $\mathbf{2 4 . 0}$ & $\mathbf{2 3 . 1}$ \\
\hline Current expenditures & 17.9 & 18.9 & 16.7 & 18.3 & 17.1 & 19.1 & 18.0 \\
\hline Capital expenditures & 4.7 & 6.8 & 5.2 & 5.4 & 3.4 & 4.5 & 4.6 \\
\hline o/w: from capital grants & 2.2 & 3.2 & 2.5 & 1.5 & - & 1.4 & 0.0 \\
\hline Net lending & 0.8 & -0.2 & 0.4 & 0.4 & 0.6 & 0.5 & 0.5 \\
\hline
\end{tabular}

Source: NSS, STS, MFE, PRSP projections

229. In 2004, consolidated budget expenditures grew by $10 \%$ and totaled around 400 billion drams, as compared with 363 billion drams in 2003. While capital expenditures grew by around $19 \%$, capital expenditures dropped by around $23 \%$, due to the completion of grant financed projects.

230. Both revenues and expenditures of the consolidated budget grew during 2004 in nominal terms, still the growth was not sufficient in order to reach the GDP ratios programmed under PRSP. In particular, the share of revenues and expenditures in GDP totaled 19.4 and $21.1 \%$ respectively, deviating from the PRSP program by -2.1 and $3.0 \%$ respectively. At the same time, the budget was completed with a $1.6 \%$ deficit in relation with GDP, instead of the programmed $2.6 \%$. Still, for the short-term period, and especially for one year period, this indicator of the share in GDP should be treated with cautiousness, since the main reasons for such developments were the discrepancies between the actual and the programmed GDP indicators - during 2003 GDP in nominal terms grew by around $19 \%$, instead of $10 \%$ programmed, while in 2004 , it grew by $16.7 \%$ instead of the programmed $9.2 \% .43$

231. Concerning the social sector, which is one of the budget priorities44, the Government pursued the policy of fulfilling its expenditure commitments. During 2004,

\footnotetext{
${ }^{43}$ Such a scenario of events was expected under the PRSP for the final stage, and a the PRSP reflected it.
}

${ }^{44}$ Education, health, social security and social insurance 
social expenditures grew faster than current expenditures and totaled around 158 billion drams $(23.8 \%$ percent growth as compared with the previous year), which resulted in certain changes within the budget portfolio towards social expenditures, and their share within the total expenditures of the consolidated budget grew by 4.4 percentage points as compared with 2003, totaling 39.6 percent. However, mainly because of higher than programmed GDP growth, in this case the programmed share in GDP could not be achieved - in 2004 the social expenditures/GDP ratio was equal to $8.35 \%$ instead of the programmed 9.3\%. Still, while revising PRSP, the Government is not going to reduce the PRSP programmed targets of social expenditures, and has already taken some steps to fill the gap both in the 2005 budget and the 2006-2008 MTEF.

232.

The 2005 budget total revenues are by around 53.4 billion drams more than the PRSP target for the same period. The monthly tax revenues exceed the PRSP target by around 51 billion drams, while non-tax revenues by 24.5 billion drams. In contrast, the approved grants are by around 20 billion drams lower than those programmed under PRSP.

233. The 2005 budget planned figure of the total expenditures is by 65.5 billion drams above the PRSP target. This growth was by more than half (around 30 billion drams) reflected by the social expenditures which are viewed as apriority under the PRSP - thus, the expenditures in the education sector are by 11.6 billion drams, in the health sector by 1.4 billion drams, and in the social security and social insurance sector by 18.9 billion drams more than under PRSP.

234. Although the 2005 budget revenues and expenditures are in nominal terms much higher than the PRSP targets, still the share of consolidated budget revenues and expenditures in GDP is lower than the PRSP target. It is expected that this imbalances will somewhat diminish during 2005. While in 2004, the imbalances between the PRSP and the actual revenues and expenditures was 2.1 and 3 percentage points, in 2005 the imbalances would lower to 1.1 and 0.9 percentage points respectively.

235. Subsequently, during the next PRSP review, the Government will focus on this issue and will take the adequate measures to adjust the budgetary expenditures and revenues with the PRSP targets, particularly, in terms of tax revenues.

\section{Poverty Reduction Strategy and Medium-Term Expenditure Framework Program}

236. One of the prerequisites for a successful implementation of the poverty 
reduction strategy is to reflect the priorities of the PRSP in the state expenditures and ensure their financing. In this context, the Government considers the medium-term expenditure framework as a key mechanism to overcome the poverty.

237. The first stage of the Government the medium-term expenditure framework was initiated in 2000, when the 2001-2003 MTEF was developed. Gradually, the capacities of the Ministry of Finance and Economy, and the line ministries in terms of programming the medium-term expenditures have become stronger45. This process was greatly fostered by the steps taken in the direction of creating a respective institutional structure. In particular, prioritizing the role and the significance of the medium-term programming of public expenditures, the Government decided in 2002 to set up a standing board of the medium-term public expenditure programs and a standing coordinating group. In addition, with the view to coordinating the process of the medium-term programming of public expenditures, in 2003 respective amendments were introduced into the law on the RA State Budget System. Under these amendments, the medium-term programming of public expenditures was considered as a constituent part of the budgetary process. In particular, the amendments provided that prior to submitting the draft annual budget, the Government should submit to the parliament a document which summarizes the three year strategy of public expenditures, as a result of which the role of the medium-term expenditure program, as a key political document, becomes even more crucial. On the other side, the Government views the medium-term program of public expenditures as one of the fundamental documents, within the framework of which the issues of attracting external assistance would be negotiated.

\footnotetext{
${ }^{45}$ While in 2003-2005, 4 line ministries were involved in designing the MTEF (Ministry of Health, Ministry of Education, Ministry of Social Security, and State Committee of Water Reserves), in 2004-2006 MTEF all the state governance bodies were involved in the MTEF design.
} 
- 64 -

Table 17. Budgetary Framework: 2005-2008 PRSP and 2006-2008 Projections

\begin{tabular}{|c|c|c|c|c|c|c|c|c|}
\hline & 2005 & 2006 & 2007 & 2008 & 2005 & 2006 & 2007 & 2008 \\
\hline & \multicolumn{4}{|c|}{\begin{tabular}{|l|l}
$P R S P$ \\
\end{tabular}} & $\begin{array}{c}\text { Budge } \\
t\end{array}$ & \multicolumn{3}{|c|}{$\begin{array}{l}2006-2008 \\
\text { MTEF }\end{array}$} \\
\hline & \multicolumn{8}{|c|}{ Dram billion } \\
\hline 1.Total revenues and grants & 318.6 & 350.8 & $\begin{array}{r}389 . \\
9\end{array}$ & $\begin{array}{r}427 . \\
9\end{array}$ & 345,4 & $\begin{array}{r}373, \\
2\end{array}$ & $\begin{array}{r}415 \\
3\end{array}$ & $\begin{array}{r}455 \\
2\end{array}$ \\
\hline Total revenues & 285.1 & 318.7 & $\begin{array}{r}359 . \\
0\end{array}$ & $\begin{array}{r}398 . \\
8\end{array}$ & 336,5 & $\begin{array}{r}365 \\
5 \\
\end{array}$ & $\begin{array}{r}407 \\
6 \\
\end{array}$ & $\begin{array}{r}454, \\
1 \\
\end{array}$ \\
\hline Tax revenues & 277.4 & 310.8 & $\begin{array}{r}347 . \\
5\end{array}$ & $\begin{array}{r}388 . \\
4\end{array}$ & 310,5 & $\begin{array}{r}358 \\
4\end{array}$ & $\begin{array}{r}400 \\
7\end{array}$ & $\begin{array}{r}448, \\
2\end{array}$ \\
\hline Non-tax and capital revenues & 7.8 & 7.9 & 11.6 & 10.5 & 26,0 & 7,1 & 6,9 & 5,9 \\
\hline Grants & 33.4 & 32.2 & 30.8 & 29.0 & 8,9 & 7,7 & 7,7 & 1,1 \\
\hline Current & 9.0 & 8.5 & 10.2 & 10.3 & 8,9 & 7,7 & 7,7 & 1,1 \\
\hline Capital & 24.4 & 23.7 & 20.6 & 18.8 & 0,0 & 0,0 & 0,0 & 0,0 \\
\hline 2. Net deficit financing & 39.2 & 38.6 & 41.3 & 45.4 & 49,3 & 66,7 & 72,9 & 79,5 \\
\hline Domestic sources & 3.6 & 4.3 & 1.2 & 5.0 & 14,6 & 31,2 & 32,6 & 34,6 \\
\hline Foreign sources & 35.6 & 34.3 & 40.1 & 40.4 & 34,7 & 35,5 & 40,3 & 44,9 \\
\hline 3.Total managed resources $(1+2)$ & 357.8 & 389.5 & $\begin{array}{r}431 . \\
2\end{array}$ & $\begin{array}{r}473 . \\
3 \\
\end{array}$ & 394,7 & $\begin{array}{r}439, \\
9\end{array}$ & $\begin{array}{r}488, \\
\end{array}$ & $\begin{array}{r}\mathbf{5 3 4} \\
7 \\
\end{array}$ \\
\hline $\begin{array}{l}\text { 4. Total expenditures and net } \\
\text { lending }\end{array}$ & 357.8 & 389.5 & $\begin{array}{r}431 . \\
2 \\
\end{array}$ & $\begin{array}{r}473 . \\
3 \\
\end{array}$ & 394,7 & $\begin{array}{r}439, \\
9\end{array}$ & $\begin{array}{r}488 \\
2 \\
\end{array}$ & $\begin{array}{r}534, \\
7 \\
\end{array}$ \\
\hline Current expenditures & 273.0 & 296.7 & $\begin{array}{r}330 . \\
2\end{array}$ & $\begin{array}{r}364 . \\
2\end{array}$ & 295,2 & $\begin{array}{r}326, \\
3 \\
\end{array}$ & $\begin{array}{r}359 \\
0 \\
\end{array}$ & $\begin{array}{r}381, \\
9 \\
\end{array}$ \\
\hline Capital expenditures & 76.5 & 81.7 & 88.0 & 96.1 & 89,4 & 97,3 & $\begin{array}{r}111 \\
5 \\
\end{array}$ & $\begin{array}{r}134, \\
9 \\
\end{array}$ \\
\hline$o / w:$ capital grants & 24.4 & 23.7 & 20.6 & 18.8 & 0,0 & 0,0 & 0,0 & 0,0 \\
\hline \multirow[t]{2}{*}{ Net lending } & 8.2 & 11.1 & 13.0 & 13.0 & 10,1 & 16,3 & 17,7 & 17,9 \\
\hline & \multicolumn{8}{|c|}{ in percent to GDP } \\
\hline 1.Total revenues and grants & 18.1 & 18.3 & 18.6 & 18.7 & 16,4 & 16,2 & 16,5 & 16,6 \\
\hline Total revenues & 16.2 & 16.6 & 17.1 & 17.4 & 16,0 & 15,9 & 16,2 & 16,5 \\
\hline Tax revenues & 15.8 & 16.2 & 16.6 & 17.0 & 14,7 & 15,6 & 15,9 & 16,3 \\
\hline Non-tax and capital revenues & 0.4 & 0.4 & 0.6 & 0.5 & 1,2 & 0,3 & 0,3 & 0,2 \\
\hline Grants & 1.9 & 1.7 & 1.5 & 1.3 & 0,4 & 0,3 & 0,3 & 0,0 \\
\hline Current & 0.5 & 0.4 & 0.5 & 0.4 & 0,4 & 0,3 & 0,3 & 0,0 \\
\hline Capital & 1.4 & 1.2 & 1.0 & 0.8 & 0,0 & 0,0 & 0,0 & 0,0 \\
\hline 2. Net deficit financing & 2.2 & 2.0 & 2.0 & 2.0 & 2,3 & 2,9 & 2,9 & 2,9 \\
\hline Domestic sources & 0.2 & 0.2 & 0.1 & 1.8 & 0,7 & 1,4 & 1,3 & 1,3 \\
\hline Foreign sources & 2.0 & 1.8 & 1.9 & 0.2 & 1,6 & 1,5 & 1,6 & 1,6 \\
\hline 3.Total managed resources $(1+2)$ & 20.4 & 20.3 & 20.6 & 20.7 & 18,7 & 19,1 & 19,4 & 19,5 \\
\hline $\begin{array}{l}\text { 4. Total expenditures and net } \\
\text { lending }\end{array}$ & 20.4 & 20.3 & 20.6 & 20.7 & 18,7 & 19,1 & 19,4 & 19,5 \\
\hline Current expenditures & 15.5 & 15.5 & 15.8 & 15.9 & 14,0 & 14,2 & 14,3 & 13,9 \\
\hline Capital expenditures & 4.4 & 4.3 & 4.2 & 4.2 & 4,2 & 4,2 & 4,4 & 4,9 \\
\hline$o / w:$ capital grants & 1.4 & 1.2 & 1.0 & 0.8 & 0,0 & 0,0 & 0,0 & 0,0 \\
\hline Net lending & 0.5 & 0.6 & 0.6 & 0.6 & 0,5 & 0,7 & 0,7 & 0,7 \\
\hline
\end{tabular}

Source: PRSP and 2005 budget. 
238.

One of the key documents for designing the 2006-2008 MTEF is the Poverty reduction Strategy Paper. The main changes in the resource package of the budgetary framework were mainly conditioned by the actually more favorable macroeconomic performance as compared with the PRSP scenario. (in particular, higher than projected GDP growth rate during 2003 and 2004) and the revision of the planned amounts of foreign assistance (in particular, grants0. As a result of the first factor tax revenues were projected to be higher (in nominal terms) as compared with the 2006-2008 projections, while due to the non-expectance of capital grants within the next 3 years, no inflows were projected. Within the 2006-2008, the programming of the state expenditures was based on the priorities set forth in the PRSP, in particular, in social sectors (health, education, social security and insurance), and improvement of the state management system. While in nominal terms the 2006-2008 MTEF budgetary framework indicators mainly exceed the PRSP targets, still there are certain imbalances in terms of the GDP ratios of these indicators, especially the tax revenues/GDP ratio.

239. Given the existing priorities and the growth perspectives, the Government takes the view that the share of the consolidated budget operations in GDP should remain within $24-25 \%$ in the near future, and will take steps for attracting the necessary funds (in particular by increasing the tax revenues). On the other side, given the scarcity of funds, the Government will make respective redistributions in funding of the sectors in favor of the sectors prioritized under the PRSP framework, with the view of ensuring the targets of the public expenditure shares within GDP. In particular, within the framework of the MTEF, this refers to the social expenditures.

240. In view of the priorities of the social expenditures (health, education, social insurance and social security), and in order to ensure the targets established under the PRSP framework, the Government planned a significant reallocation of the budgetary financing under the 2006-2008 MTEF, as compared with the PRSP targets. The 20062008 MTEF plans a progressive growth of the social expenditures within the total budgetary expenditures, as a result of which the share of social expenditures will grow by 3.7 percentage points as compared with 34.6 panned figure under the 2005 state budget, and would total $38.3 \%$ (Table 18). 
Table 18. State Budget Expenditures Under PRSP and 2006-2008MTEF

\begin{tabular}{|c|c|c|c|c|c|c|c|c|}
\hline & 2005 & 2006 & 2007 & 2008 & 2005 & 2006 & 2007 & 2008 \\
\hline & \multicolumn{4}{|c|}{ PRSP } & $\begin{array}{c}\text { Budge } \\
t\end{array}$ & \multicolumn{3}{|c|}{$M T E F$} \\
\hline & \multicolumn{8}{|c|}{ Dram billion } \\
\hline Total social expenditures & 120.0 & 137.9 & 155.0 & 177.6 & 136,5 & 156,9 & 180,5 & 205 \\
\hline Education & 47.9 & 54.8 & 62.8 & 76.9 & 57,7 & 66 & 75,3 & 90,4 \\
\hline Health & 30.8 & 35.5 & 40.9 & 46.9 & 32,2 & 37,3 & 48,4 & 56,4 \\
\hline Social insurance and security & 41.4 & 47.6 & 51.3 & 53.7 & 46,6 & 53,6 & 56,8 & 58,2 \\
\hline \multirow[t]{2}{*}{ o/w target benefits } & 20.2 & 24.9 & 27.2 & 29.7 & 20 & 24,7 & 26,6 & 27,2 \\
\hline & \multicolumn{8}{|c|}{ In percent to previous year } \\
\hline Total social expenditures & 19.6 & 14.9 & 12.3 & 14.6 & & 14,9 & 15,0 & 13,6 \\
\hline Education & 21.6 & 14.5 & 14.6 & 22.5 & & 14,4 & 14,1 & 20,1 \\
\hline Health & 23.5 & 15.4 & 15.1 & 14.7 & & 15,8 & 29,8 & 16,5 \\
\hline Social insurance and security & 14.7 & 15.1 & 7.7 & 4.7 & & 15,0 & 6,0 & 2,5 \\
\hline \multirow[t]{2}{*}{ o/w target benefits } & 25.6 & 23.4 & 9.2 & 9.2 & & 23,5 & 7,7 & 2,3 \\
\hline & \multicolumn{8}{|c|}{ In percent to GDP } \\
\hline Total social expenditures & 6.8 & 7.2 & 7.4 & 7.8 & 6,5 & 6,8 & 7,2 & 7,5 \\
\hline Education & 2.7 & 2.9 & 3.0 & 3.4 & 2,7 & 2,9 & 3,0 & 3,3 \\
\hline Health & 1.8 & 1.9 & 2.0 & 2.1 & 1,5 & 1,6 & 1,9 & 2,1 \\
\hline Social insurance and security & 2.4 & 2.5 & 2.4 & 2.3 & 2,2 & 2,3 & 2,3 & 2,1 \\
\hline \multirow[t]{2}{*}{ o/w target benefits } & 1.2 & 1.3 & 1.3 & 1.3 & 0,9 & 1,1 & 1,1 & 1,0 \\
\hline & \multicolumn{8}{|c|}{ In percent to state budget expenditures } \\
\hline Total social expenditures & 33.6 & 35.4 & 35.9 & 37.5 & 34,6 & 35,7 & 37,0 & 38,3 \\
\hline Education & 13.4 & 14.1 & 14.6 & 16.3 & 14,6 & 15,0 & 15,4 & 16,9 \\
\hline Health & 8.6 & 9.2 & 9.5 & 9.9 & 8,2 & 8,5 & 9,9 & 10,5 \\
\hline Social insurance and security & 11.6 & 12.2 & 11.9 & 11.3 & 11,8 & 12,2 & 11,6 & 10,9 \\
\hline o/w target benefits & 5.6 & 6.4 & 6.3 & 6.3 & 5,1 & 5,6 & 5,4 & 5,1 \\
\hline
\end{tabular}

\section{The Measures Undertaken for Ensuring Public Participation in the PRSP Implementation Process}

241.

After adopting the PRSP in August 2003 the RA Government initiated implementation of the PRSP. In the framework of the latter activities on introducing the PRSP Implementation mechanisms were undertaken.

242. Realizing that the PRSP implementation, monitoring and evaluation process with the involvement of all the stakeholders is one of the main preconditions for successful implementation of the PRSP. Thus, the RA Government proposed to all the interested parties to become a partner in the PRSP implementation, monitoring and evaluation process, which will give an opportunity to maintain the positive experience of active public participation gained at the PRSP elaboration period and to develop the 
latter at the project implementation stage. The latter should have been better organized and put at the institutional basis contributing to the establishment of the social partnership.

243. On March 31, 2004, a meeting with the NGOs was organized. During the meeting regulations of public participation at the decision making process were presented. In the result of the activities undertaken on July 30, 2004 a memorandum on initiating negotiations over the social partnership in the framework of the PRSP was signed by the parties engaged in the process. This served a basis for introducing participatory mechanisms into the PRSP implementation process.

244. In the result of the discussions held with all the stakeholders on October 30, 2004 the PRSP Social Partnership Agreement was signed. The parties, which signed the agreement, represent public administration, non-governmental units, business sphere, trade unions and the Armenian Apostolic Church.

245. Reasoning form the regulations set in the PRSP Social Partnership Agreement a PRSP implementation system consisting of the PRSP Steering Committee (established by the decree \# 43 of the RA Prime Minister dated January 25), and the PRSP Working Group was established. The parties that signed the Agreement are represented in the PRSP Working Group and PRSP Steering Committee.

246. At the opening session of the PRSP Steering Committee several important documents that served a background for further coordination of the PRSP implementation process were approved. The PRSP Steering Committee approved the charter and the personnel of the PRSP Working Group as well as the time table of the actions to be implemented. For ensuring public awareness and providing feedback the PRSP Open Forum was established, the action plan for 2005 PRSP Open Forum was approved and the Open Forum Coordinator was appointed.

247. At the same time a Joint Analytical Group was established to support the preparation of the PRSP Annual Report and PRSP update.

248. The PRSP Open Forum, which started functioning on February 23, 2005 has already realized eleven events. Representatives of the interested governmental and nongovernmental institutions, PRSP experts, international organization representatives, as well as representatives of the organizations that have conducted relevant surveys in the field have taken part at the events organized by the PRSP Open Forum. Thus, over 200 NGOs and individuals from different cities and rural communities of Armenia took part at the meeting. To ensure the function of reporting the representatives of the 
governmental institutions have presented the current situation in the fields and thus discussions with the involvement of all the stakeholders were conducted.

249.

On April 14, 2005 in Tekeyan Center the first forum took place. The issue discussed was the drinking water tariff increase by the RA Public Service Regulatory Committee decision adopted on March 22, 2005. The objective of the forum was to find out whether the new tariff system was consistent with the PRSP priorities and identify possible social impact, particularly, on the socially vulnerable groups of population. The solutions proposed by the participants mainly referred to water management sector reforms. The mechanisms aimed at protecting the poor in case of water tariff increase were discussed. The results of the discussion have been summed up by the Open Forum, with an expectation that the latter will be applied in new water tariff policy elaboration.

250. On May 13, 2005 within the scope of the PRSP Open Forum activities, an expert discussion on the "PSIA: (Poverty and Social Impact Assessment) Presentation of the Results" was conducted. The survey realized with the GTZ support was concerning mainly the reforms envisaged in the social sector; particularly it dealt with the problems that exist in the employment sector and poverty family benefit system. The PSIA in the general context of social sector reforms implemented in Armenia was aimed to support well-grounded decision making process referring to the review of efficiency of the policies implemented in the selected fields, setting relevant indicators and standards and applying analysis of the possible consequences. At the same time, the PSIA gives an opportunity to reveal the problems, which are not solved yet, but require serious consideration.

251. On May 31, 2005 in the framework of the PRSP Open Forum activities a workshop took place during which the UNDP Armenia, Yerevan office presented the report on "Human Poverty and the Pro-Poor Policies". The anticipated results of the workshop were to develop in each sector group comments and proposals aimed at improvement of the quality of the report and involve expert and public opinion in the latter. The results of the workshop and the constructive proposals have been summed up and will be reflected in the final report.

252. On July 1, 2005 in Armavir marz a discussion on land consolidation problems was organized at the initiative of the PRSP Open Forum. The subject for discussion was the land consolidation process in Armavair marz and in Ararat Valley in general. It was mentioned that the land consolidation process needed a strong monitoring system and effective public policy implementation. 
253.

On August 24, 2005 round-table/discussion was organized within the scope of the PRSP Open Forum at the secondary school No 4 in the town of Vanadzor. The main topic of the discussion was "Problems of General Education Quality and Accessibility Improvement in Lori Marz". The discussion mainly covered two issues, namely, quality and accessibility of general education. However, the problems of pre-school and of higher education institutions were also considered. For the solution of problems existing in the general education sector it was proposed to introduce legislative and systemic changes into the educational policy and strategy, as well as to view the education as a global, unified concept - from preschool up to higher education. It is also necessary to develop and implement programs on getting additional financial sources for schools. A special importance should be provided to the training of the personnel and necessity to change the public attitude.

254. On August 29, 2005 at the initiative of the Open Forum and within the scope of "The Fifth Wheel" TV talk-show broadcasted on the Armenian Public TV, a discussion was organized where the issue of public participation in the PRSP implementation process was presented. During the talk-show the importance of involvement of certain groups and wide sections of the society into the PRSP implementation process, and in the execution of state programs in general was emphasized.

255. On September 30, 2005 at the initiative of the UNDP and within the scope of the PRSP Open Forum a meeting was organized with NGO representatives dealing with vulnerable groups of the population in Gyumri. The main objective of the meeting was to discuss capacity building of the NGOs that deal with vulnerable groups, the mechanisms of cooperation between the government and NGOs, as well the efficiency of transferring certain functions of the government to the NGOs. In the result of the discussion, it was suggested to delegate some of the functions related to poverty mitigation among vulnerable groups that are currently implemented by the governmental institutions, to the specialized NGOs which would meet the requirements of efficient provision of the services.

256. On October 12, 2005 in the framework of the PRSP Open Forum activities a round-table was organized in the town of Artashat. The topic for discussion was the "Armenian Rural Community: Which are the Ways to Prosperity (comparative analysis of the existing situation in Verin Artashat and Taperakan villages)?" The purpose of the discussion was to present the socio-economic situation, conduct comparative analysis of 
the living conditions in the above-mentioned villages, as well as to analyze the development trends in the communities, assess the existing tendencies and propose possible solutions.

257. On October 26, 2005 a round table discussion was organized in the town of Hrazdan within the scope of the PRSP Open Forum events. The subject for discussion was the "Issues of Poverty Reduction in a Medium-Sized City". During the discussion the socio-economic situation in the towns of Hrazdan and Charentsavan was presented. The objective of the discussion was to analyze the living conditions, development trends in the given towns, reveal the up to date problems, as well as evaluate existing tendencies and make recommendations on possible solutions.

258. On December 14-15 2005, a workshop devoted to the three-midterm priorities (2005-2007) set by the PRSP Social Partnership Agreement signed on October 30, 2005 was organized by the PRSP Open Forum in the Writers' House in Tsaghkadzor. The main purpose of the workshop was to present and review the results of the PRSP priorities implementation process, considering them in the context of partnership establishment. The partners who have signed the agreement, namely PRSP Joint Analytical Group experts, representatives of the line ministries, NGOs, as well as other stakeholders took part in the workshop. The outcomes of cooperation between the PRSP Steering Committee, PRSP Working Group and Open Forum during 2005 were discussed. The result of the survey conducted at the initiative of the PRSP Open Forum, the outcome of the in-depth interviews conducted among the parties who have signed the agreement, as well as the results of the analysis of the protocols of the PRSP Working Group and Steering Committee sessions were presented to the participants of the workshop.

259. After the discussion, the partners presented several recommendations and comments on the issues discussed. In terms of improvement of the partnership efficiency and enhancement of participatory mechanisms, the issues related to rising public awareness and strengthening the links among partners were emphasized. It was proposed to bring the action plan of the PRSP line ministries in to accordance with the marz and community need assessment requirements. In terms of improvement of the mechanisms it was proposed also to develop and adopt a law on social partnership and to specify the types of intra-communal, inter-communal cooperation and the ways of cooperation with the church. With respect to raise of public awareness it was proposed to provide necessary training through organization of workshops and consultations, special 
importance was provided to the establishment of analytical and resource center. As for enhancement of cooperation, it was mentioned that the rights and liabilities of the parties involved in the PRSP management system should be defined and relevant feedback should be ensured.

260. The following conclusions were derived on the rights and liabilities of the stakeholders. The responsibility for realization of the activities is put on the governmental side, but there has not been any monitoring conducted by any of the parties engaged. It was proposed to review the agreement and define precisely the rights and liabilities of the partiers. It was also mentioned that the PRSP was not defined by regions and targets as a consequence of which the division of functions has become impossible. Thus, it was proposed to establish a PRSP Project Implementation Unit (PIU) to increase management efficiency.

261. For enhancement of the professional skills and capacities of the parties, as well as for increase of transparency of the PRSP implementation process it was proposed to establish a common system of monitoring, organize training on monitoring and control implementation, to ensure active involvement of the marz mass media.

262. At the same time parallel to the discussions organized by the PRSP Open Forum in July-August 2005 public discussions devoted to the PRSP 2004 Sector Reports (education, heath care, social protection, agriculture, environmental protection, business environment and SME development) were held in the RA Ministry of Finance and Economy.

\section{PRSP and the Donor Community Support Coordination}

263. The representatives of the donor community take active part at the PRSP discussions presenting their approaches to the solution of the existing problems. It created additional basis for enhancement of the cooperation between the RA Government and donor community. The government has gained credit, and the donor community having taken active part at the PRSP discussions will be involved also in the implementation process. The donor community has received explicit guidelines from the Armenian community on the main country development priorities for the coming years.

264. As a first step towards enhancement of the cooperation in the framework of the PRSP implementation can be considered the fact that when setting the main trends of the midterm programs the PRSP priorities have been taken into account. Among these projects are; the World Bank, IMF, UNDP, USAID, EU. 

by the IMF based on the PRSP.

266.

In June 2004, the World Bank adopted "Country Development Strategy, in the framework of which from a large list of activities special emphasis was put on the three priority trends, namely to the economic growth through strengthening private sector development, directing economic growth towards the poor, reducing non-income poverty. These three trends suit best to the comparative advantages of the World Bank and are complemented by the activities of other donors. At the initial stage long term country developments targets are taken into the Country Development Strategy framework. On the basis of the above-mentioned targets, outcomes to be achieved in a four year period of the "Country Development Strategy" have been specified.

267. To assist Armenia on its way to the PRSP implementation and achieving Millennium Development Goals UNDAF a 2005-2009 strategy paper on country assistance was elaborated, which has been developed in full accordance with the PRSP goals and priorities. According to the strategy adopted from the list of the PRSP priorities UN will mostly focus on the poverty reduction and inequity mitigation, on the raise of quality and accessibility of the main social services provided, increase of reporting of the governmental institutions and transparency of their activities, increase natural resource management efficiency and stimulation of technologies that meet environmental requirements.

268. The main tasks of the action plan approved in the framework EU TACIS program aimed to support implementation of the institutional, legislative and administrative reforms and overcome the social consequences of the transitional period. The latter are also reflected in the PRSP.

269. After the adoption of the PRSP the bilateral programs implemented by DFID have been brought into compliance with the PRSP policies and priorities. The DFID project for 2004-2007 on Regional assistance to the Central Asian countries, South Caucasus and Moldova serve an illustration to the above said.

270. The USAID 2004-2008 support strategy for Armenia has been designed in 2003. The strategy ha been ellaborated in tight cooperation with the RA Government. Five strategic targets have been defined in the paper: increase of employment in the compatible private sector, ensure accessibility of sustainable and safe power supply and water sources, improved democratic governance, and ensure accessibility of highquality, sustainable primary health care and improvement of the social security system. 
The latter are fully correspond to the main trends, which are considered to be a priority within the PRSP scope.

271. Election of Armenia by the Millennium Challenge Account (MCA) board of directors as a country eligible to apply to MCA for assistance is an additional possibility for cooperation in the framework of the PRSP.

272. The application for assistance presented within the scope of the MCA envisages directing financial capacities towards strategic investments in the irrigation and community road construction spheres. The main objective of the investments is to increase the agricultural production in the poor rural regions.

273. The specific direction of poverty reduction in the format of public infrastructure are fully consistent with the PRSP adopted in August 2003 by the RA Government and it directly relates to the obstacles on the way of rural poverty reduction. The above mentioned obstacles are presented at the PRSP first progress report prepared in September 2004.

\section{Development and Introduction Process of the PRSP Monitoring and Evaluation System}

274. Activities on the PRSP monitoring and evaluation system development were initiated in August 2003, right after the adoption of the Program by the PRSP working group. The World Bank, GTZ and UNDP continuously supported the above process. In November 2003 a subgroup within the PRSP WG was created aimed at development of monitoring strategy, and more than 15 independent experts and one consulting company (UNDP was supporting to the activities of the latter) were involved for the development of indicators' system.

275. In November 2004 it became possible to review the mentioned activities, when the concept of the PRSP monitoring indicators' system was approved by the RA Government Decree N1780-A. The concept provided all the required prerequisites for introducing the program monitoring system. In the process of the PRSP implementation, the concept also enabled to assess the process realistically, and as a result make necessary clarifications and changes in the PRSP priority policies and action plan.

276. The PRSP monitoring system encompasses 177 indicators, out of which 36 are target indicators, and 141 factor indicators that are clustered in the following separate group: (i) poverty reduction and improved living conditions, (ii) education, (iii) health, (iv) basic public services and housing conditions, (v) civil isolation and inequity, and 
(vi) sustainable environmental development.

277. The system of the monitoring indicators is harmonized with the Millennium Development Indicators framework as much as possible.

Table 19. Summarized statistical data of the PRSP monitoring indicators

\begin{tabular}{|l|l|c|c|c|}
\hline & & Target & Factor & Total \\
\hline & Total & $\mathbf{3 6}$ & $\mathbf{1 4 1}$ & $\mathbf{1 7 7}$ \\
\hline A & Poverty reduction and improved wellbeing & 3 & 41 & 44 \\
\hline B & Education & 6 & 23 & 29 \\
\hline C & Health & 9 & 32 & 41 \\
\hline D & Main public services and housing conditions & 10 & 12 & 22 \\
\hline E & Civil isolation and inequity & 5 & 27 & 32 \\
\hline F & Sustainable environmental development & 3 & 6 & 9 \\
\hline
\end{tabular}

278.

The necessity to submit actual (including historical range of 2001-2003) indicators and targets related to competences of the RA Ministry of Finance and Economy was also stipulated by the decree on the approval of the PRSP monitoring indicators' system concept.

279. The RA Ministry of Finance and Economy has already faced difficulties during the review of the 2001-2004 indicators submitted by the RA state governance entities, which did not enable to collect complete data on the monitoring indicators 2001-2004, as well as to define targets in terms of all the indicators for the upcoming years. Thus, data on 40 indicators out of 177 (for the years 2001-2004) envisaged by the PRSP monitoring indicators' system was not available fully, and for more than 30 indicators the data was partially available.

280. As for setting targets of the monitoring indicators for the upcoming years, targets for 24 indicators were defined by the Poverty Reduction Strategy Paper, and corresponding governance entities established targets for 28 indicators.

281. Evaluation of the 2004 PRSP implementation progress, in the context of target indicators set by the PRSP, according to the methodology envisaged by the concept of the PRSP monitoring indicators' system is presented in the Table 20. 
Table 20. Evaluation of the 2004 PRSP implementation46 progress according to the methodology envisaged by the concept on the PRSP monitoring indicators' system

\begin{tabular}{|c|c|c|c|c|c|}
\hline \multirow[b]{2}{*}{$\mathbf{N}$} & \multirow[b]{2}{*}{ Name of Indicators } & \multirow{2}{*}{$\begin{array}{l}2001 \\
\begin{array}{l}\text { Basic } \\
\text { year }\end{array}\end{array}$} & \multicolumn{2}{|l|}{2004} & \multirow{2}{*}{$\begin{array}{l}\text { Progress } \\
\text { Assessment }\end{array}$} \\
\hline & & & Program & Actual & \\
\hline A1 & $\begin{array}{l}\text { Number, percentage of poor with regard to the number of existing } \\
\text { population }\end{array}$ & 50.9 & 43.7 & 39.0 & 5 (Executed) \\
\hline $\mathrm{A} 2$ & $\begin{array}{l}\text { Number, percentage of adverse poor with regard to existing } \\
\text { population }\end{array}$ & 16.0 & 14.7 & 7.2 & 5 ( Executed) \\
\hline A3 & GDP per capita, thousand drams per 2001 sustainable prices & 365.8 & 470.5 & 520.0 & 5 (Executed) \\
\hline a1.5 & $\begin{array}{l}\text { Added value in agriculture, difference with regard to the previous } \\
\text { year in percentage }\end{array}$ & 11.7 & 2.8 & 14.5 & 5 (Executed) \\
\hline a1.6 & Inventory of agricultural products, percentage & 49.9 & 46.5 & 55.7 & 5 (Executed) \\
\hline a1.7 & $\begin{array}{l}\text { Taxation of agricultural sector with regard to added value in } \\
\text { agriculture, percentage }\end{array}$ & 9398.0 & 3.4 & 2.0 & 2 (Incomplete) \\
\hline $\mathrm{a} 1.8$ & $\begin{array}{l}\text { Consolidated budget expenditures in agricultural sector, million } \\
\text { drams }\end{array}$ & 17019.3 & 17000.0 & 16473.8 & 4 (Good) \\
\hline a1.9 & Public capital expenditures in irrigation system, million drams & 6162.7 & 17200.0 & 4348.3 & $1(\mathrm{Bad})$ \\
\hline $\mathrm{a} 1.10$ & $\begin{array}{l}\text { Consolidated budget expenditures in the road economy sector, } \\
\text { million drams } / \mathrm{km}\end{array}$ & 0.5 & 1.7 & 1.7 & 5 (Executed) \\
\hline a1.13(ii) & $\begin{array}{l}\text { Public expenditures in education and health sectors with regard to } \\
\text { general non percentage expenditures of the consolidated budget, } \\
\text { percentage }\end{array}$ & 16.3 & 18.0 & 18.8 & 5 (Executed) \\
\hline a2.1 & Gini coefficient of the centralized revenues & 0.528 & 0.498 & 0.387 & 5 (Executed) \\
\hline $\mathrm{a} 2.3$ & $\begin{array}{l}\text { Incomes of the richest population ( } 20 \%) \text { with regard to the poorest } \\
(20 \%) / \text { times }\end{array}$ & & 13.5 & 10.6 & 5 (Executed) \\
\hline $\mathrm{a} 2.4$ & $\begin{array}{l}\text { Average monthly pension with regard to poverty general line, } \\
\text { percentage }\end{array}$ & 38.1 & 58.0 & 59.4 & 5 (Executed) \\
\hline $\mathrm{a} 2.5$ & $\begin{array}{l}\text { Average monthly social pension with regard to poverty food line, } \\
\text { percentage }\end{array}$ & 45.9 & 61.3 & 39.7 & 2 (Incomplete) \\
\hline a2.7 & $\begin{array}{l}\text { Consolidated budget expenditures for paying pensions, percentage } \\
\text { for GDP }\end{array}$ & 2.8 & 2.9 & 2.8 & 4 (Good) \\
\hline $\mathrm{a} 2.8$ & $\begin{array}{l}\text { Consolidated budget expenditures for family benefits, percentage } \\
\text { for GDP }\end{array}$ & 1.4 & 1.0 & 0.9 & 4 (Good) \\
\hline b1.1(ii) & $\begin{array}{l}\text { Consolidated budget expenditures in education, percentage for } \\
\text { GDP }\end{array}$ & 1.7 & 1.9 & 1.8 & 4 (Good) \\
\hline c1.1(ii) & $\begin{array}{l}\text { Consolidated budget expenditures in health sector, percentage for } \\
\text { GDP }\end{array}$ & 1.3 & 1.5 & 1.3 & 3 (Satisfactory) \\
\hline $\mathrm{e} 2.1$ & Tax revenues of the state budget, percentage for GDP & 14.4 & 15.3 & 14.1 & 4 (Good) \\
\hline e2.4 & $\begin{array}{l}\text { Increase of average salary (revenue base), percentage for the } \\
\text { previous year }\end{array}$ & 10.6 & 8.9 & 15.9 & 5 (Executed) \\
\hline & General Assessment of the Progress & & & & 4.23 (Good) \\
\hline
\end{tabular}

282. Though the assessment presented in the table is an overview of the limited number of indicators, yet to certain extent it reflects the progress of the PRSP implementation in 2004.

283. The necessity to define the requirements for submitting actual indicators and

${ }^{46}$ Evaluation was done for those indicators that had 2004 targets set by the PRSP 
targets related to the competences of the RA Ministry of Finance and Economy, as well as the format of the PRSP implementation report submission, was also stipulated by the decree about the approval of the concept on the PRSP monitoring indicators' system.

284. The overview process of the first reports on PRSP implementation submitted by the state governance entities in 2004 showed that the reports in terms of their formats rather differ from each other, which substantially complicates the overview activities. The necessity to define universal format for the reports is justified by that reason, which was fixed by the RA Government decree mentioned above.

285. For that purpose, the format and submission requirements of the reports to be submitted by the RA state governance entities were approved by the RA Government Decree N 1002-N dated July 14, 2005.

Table 21. Format of submitting data on the PRSP activities implementation

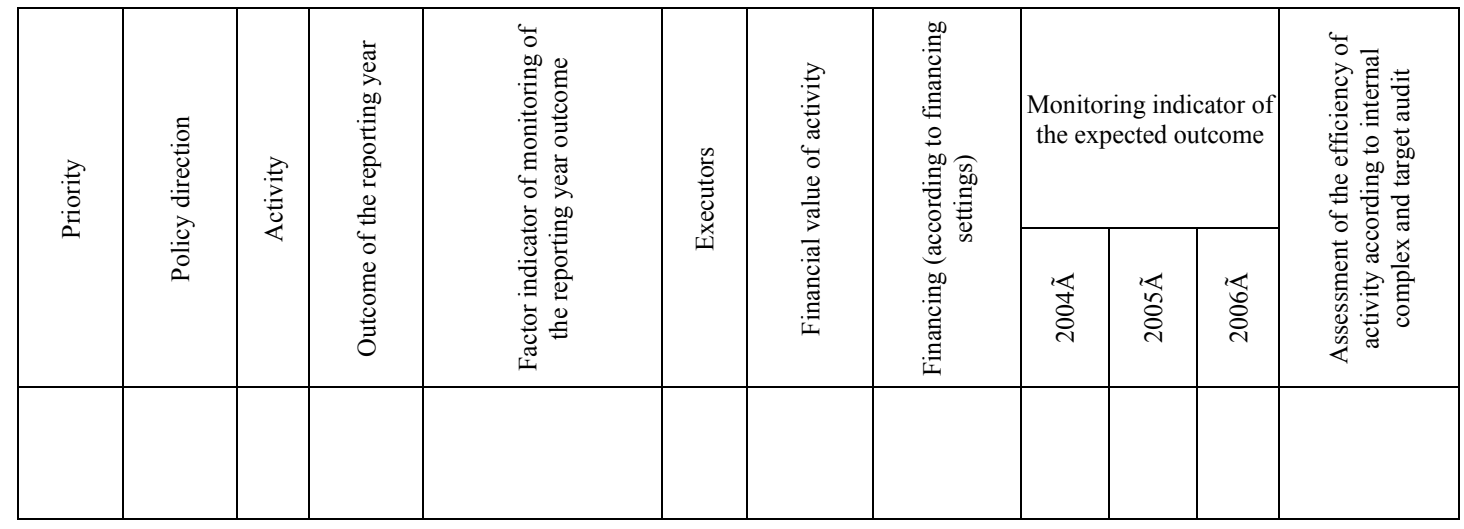

286. The Government signifies efficient functioning of the PRSP monitoring comprehensive system not only in terms of assuring progress evaluation of the set objectives, but also in terms of making the PRSP update more effective and targeted. First of all it implies sustainability of the quality information flows and accessibility.

287. The RA Ministry of Finance and Economy has already faced difficulties during the review of the 2001-2004 indicators submitted by the RA state governance entities. Those difficulties are related to both inexplicit methodology of calculating certain indicators and lack of experience in calculating certain group of indicators. To this end, after the upcoming PRSP update the Government will make certain clarifications in the PRSP monitoring indicators' system that will proceed from the requirements resulted from the PRSP update, as well as problems identified during the overview of the indicators. 


\section{Possible Changes and Clarifications of the PRSP Indicators}

288. It can be witnessed that economic situation stemmed from the 2003-2004 developments was more favorable than it was anticipated by the PRSP scenario. In the first semester of 2005 the economy developed more rapidly, and most likely, the current year will be concluded with higher economic growth, than it was anticipated initially.

289. The course of this kind of developments requires update of the PRSP basic indicators projection. One of the main indicators, prognosis of which should be updated, is gross domestic product (GDP). During the last two years the increase of GDP has made up about 12 percent. Current tendencies of the development and analysis of the related factors confirm that midterm (2005-2008) PRSP prognosis should be updated. The latter is justified by both changes in indicators of the basic year (2003) and differences of the anticipated projections based on the midterm PRSP scenario. According to projections, rapidity of the economic growth in that period of time will be higher by 1-2 percentage points than it was anticipated by the PRSP microeconomic framework. Moreover, the above increase will be assured at the expense of industrial, constructional and services spheres.

290. Increased speed of the economic growth will also have an impact on the population's income. In 2004 the population's incomes have increased at a rapid pace and compared to the PRSP scenario certain increase in rate is anticipated in the midterm section. Particularly, it relates to the employment income, whereas in case of the revenues generated from the trade of agricultural products, tendencies in income will not differ much from those anticipated in the PRSP framework. Nevertheless, projections of revenue indicators require additional research.

291. Next group of indicators, which are referred in this context, is the budget revenues and expenditures. Rapid growth of the GDP brought to expansion of taxation basis, which resulted in need to update nominal rate of tax revenues. As for the tax revenues, namely GDP ratio projections, during the upcoming 2-3 years it will be to certain extent less than it is projected by the PRSP scenario. The latter is mostly predetermined by the fact that additional economic growth during the mentioned years was in tax-exempt sectors. Nevertheless, tax revenues, namely trends in GDP ratio changes will remain the same, and will increase by $0.3-0.4$ percentage points rate annually. 
Expansion of budget resource package by nominal rate will result in corresponding clarification of expenditure programs. The Government will make those clarifications proceeding from the PRSP priorities. Main share of the additional resources will take up social sectors (health, education, social protection) and infrastructure. The Government will make relevant redistributions among the sectors to assure as much as possible expenditures in priority directions, namely the PRSP program indicators in terms of GDP ratio. Particularly, it relates to social expenditures and corresponding approach was applied in 2006-2008 midterm expenditure programs.

293. Update of the state expenditure program can also result in possible changes in the pprojected budget due to foreign support inflows. Paticularly, there will be a need for the update in terms of anticipated additional inflows within the scope of US Government " Millennium Challenges" program, as well as in terms of implementation of the new program of Linse foundation. In this case as well, the Government will make corresponding inter and intra sector reallocations among the public expenditure programs based on the PRSP priorities and goals.

294. Taking into account positive trends of the natural growth of the last two years, projections related to population number also should be reviewed. Besides, the constant number of the population will be estimated and the PRSP corresponding indicators that were calculated based on the existing number of the population will be recalculated on the ground of the population's constant number ${ }^{47}$.

295. Referring to the possible review of the indicators that illustrate inequity, it should be verified that according to 2003 and 2004 household survey results there was a drastic reduction of inequity. As a result, the latter requires review of program indicators of both expenditures as well as 2004 actual and program indicators' differences predetermined Gini coefficient of the revenues. Nevertheless, during the review of those indicators the Government will show caution, especially, in case of consideration of midterm trends of inequity reduction.

296. Review of the main macroeconomic and budget framework indicators will result in certain displacements in terms of poverty rate indicators. Particularly, taking into account that according to preliminary assessments in 2003 and 2004 poverty reduced more swiftly than it was projected by the PRSP. Moreover, the main factors that

\footnotetext{
${ }^{47}$ In the scope of the PRSP the indicator for the existing number of population was used. In this respect the information is available only during the years of census.
} 
contributed to poverty reduction were the progressive increase in poor population income due to economic growth and increase of the social transfers. That is, the main impact was assured at the expense of the factors differentiated in the PRSP. In the scope of this report the update of the poverty rate was undertaken in 2004 by making corresponding clarifications in terms of actual indicators, namely, assuming that trends of the poverty reduction do not change in the PRSP scenario (Diagram 1). Though at this stage rapid reduction of the poverty rate can be observed, nevertheless, at least in the mid-term perspective, the Government will refer to clarification of poverty reduction trends in the PRSP update.

\section{DIAGRAM 1.2004-2015 UPDATED PROJECTION OF THE POVERTY RATE}

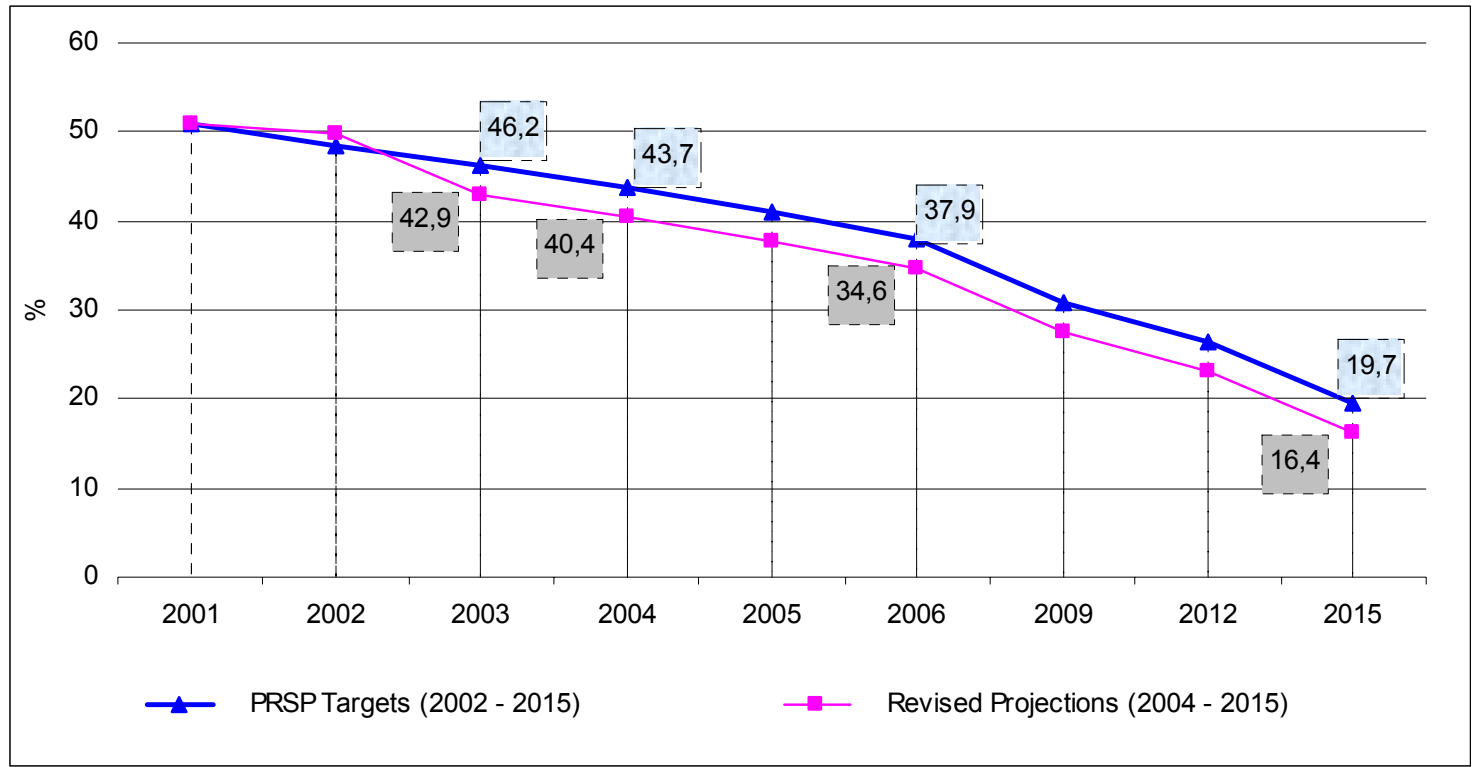

297.

During the PRSP update the Government will refer to review of other target indicators. In this respect, the Government will update those indicators that have quantitative targets in the PRSP. Moreover, the Government will also set quantitative targets for the target and main factor indicators included in the PRSP monitoring indicators' system, which are not presented in PRSP. Depending on how much the indicators are sensitive in the time period, the targets will be implemented according to one of the following methods: (i) targets will be defined for each year or (ii) certain period of time 48 (upcoming 3 or 5 years). Besides, for certain indicators targets can be set as intervals or upper (lower) margin.

\footnotetext{
${ }^{48}$ E.g. assure $X$ percent increase for indicator A with respect to the (basic) year in $(t+5)$ years.
} 
Annex 1. Progress in poverty reduction: summary indicators

\begin{tabular}{|c|c|c|c|c|}
\hline & 2002 & 2003 & \multicolumn{2}{|c|}{2004} \\
\hline & Actual & & PRSP & Prelim. \\
\hline \multicolumn{5}{|l|}{ (i) POVERTY AND INEQUALITY } \\
\hline Population below poverty line, \% of total population & 49.7 & 42.9 & 43.7 & 39.0 \\
\hline including: population below food poverty line, \% of total population & 13.1 & 7.4 & 14.7 & 7.2 \\
\hline Gini coefficient of income concentration & 0.451 & 0.438 & 0.498 & 0.413 \\
\hline Incomes of the poorest quantile, \% of incomes of the richest quantile & 6.8 & 7.5 & 7.4 & 9.4 \\
\hline \multicolumn{5}{|l|}{ (ii) HUMAN POVERY } \\
\hline General secondary school completion rate, \% & 66.5 & 67.9 & $\ldots$ & $\ldots$ \\
\hline Child mortality rate, per 1000 live births $^{2}$ & 16.7 & 13.6 & $\ldots$ & 13.0 \\
\hline Mother mortality rate, per 100000 live births ${ }^{2,3}$ & 33.5 & 22.0 & $\ldots$ & $\ldots$ \\
\hline Access to drinking water, $\%{ }^{4}$ & 89.1 & 91.0 & $\ldots$ & 91.5 \\
\hline Urban population & 97.0 & 97.8 & $\ldots$ & 96.7 \\
\hline Rural population & 77.0 & 80.6 & $\ldots$ & 81.2 \\
\hline \multicolumn{5}{|l|}{ (iii) LIVING STANDARDS AND SOCIAL EXPENDITURE } \\
\hline GDP per capita, thousand drums & 424.2 & 505.9 & 533 & 590.1 \\
\hline GDP per capita, USD & 623.0 & 874.0 & 904 & 1106.0 \\
\hline Average monthly wage, drums & 26,444 & 33,871 & 32,078 & 42,008 \\
\hline Minimum monthly wage, drums & 5,000 & 5,000 & 12,767 & 13,000 \\
\hline Monthly extreme (food) poverty line, drums & 7,516 & 7,742 & 7,827 & 8,954 \\
\hline Monthly poverty line, drums & 12,261 & 12,629 & 12,767 & 14,595 \\
\hline Social expenditure, $\%$ of GDP & 7.8 & 7.9 & 9.3 & 8.4 \\
\hline of which: education, \% of GDP & 2.2 & 2.2 & 2.7 & 2.5 \\
\hline health, \% of GDP & 1.2 & 1.2 & 1.5 & 1.3 \\
\hline social protection, \% of GDP & 4.5 & 4.5 & 5.1 & 4.5 \\
\hline \multicolumn{5}{|l|}{ (iv) MACROECONOMIC INDICATORS } \\
\hline Nominal GDP, billion drums & 1,362 & 1,625 & 1.609 & 1,896 \\
\hline Real GDP, year-on-year \% change & 13.2 & 14.0 & 6.0 & 10.1 \\
\hline Investments, \% of GDP & 21.7 & 24.3 & 20.6 & 24.0 \\
\hline Period average $\mathrm{CPI}$, year-on-year \% change & 1.1 & 4.7 & 3.0 & 7.0 \\
\hline Period average exchange rate, drum/US dollar & 573.4 & 578.8 & 589.3 & 533.5 \\
\hline Exports of goods and services, million US dollars & 698 & 903 & 840 & 985 \\
\hline Imports of goods and services, million US dollars & $-1,107$ & -1406 & -1.256 & -1514 \\
\hline Current account balance, $\%$ of GDP & -6.2 & -6.7 & -5.8 & -4.5 \\
\hline \multicolumn{5}{|l|}{ (v) FISCAL SECTOR ${ }^{6}$} \\
\hline Total revenue and grants, $\%$ of GDP & 22.4 & 21.5 & 21.5 & 19.4 \\
\hline of which: tax revenue, \% of GDP & 17.8 & 17.2 & 18.8 & 17.2 \\
\hline Total expenditure and net lending, \% of GDP & 23.3 & 22.4 & 24.1 & 21.1 \\
\hline of which: capital expenditure, \% of GDP & 4.7 & 5.2 & 5.4 & 3.4 \\
\hline Overall balance, $\%$ of GDP & -0.9 & -0.9 & -2.6 & -1.6 \\
\hline
\end{tabular}

Data for 2000. ${ }^{2}$ Projections are based on official data of the National Statistical Service. ${ }^{3}$ Three-year average. ${ }^{4}$ PRSP projections are based on indicators of the availability of centralized water supply in residential units; the forecasts for these indicators will be adjusted accordingly at the next PRSP update. ${ }^{5}$ PRSP corresponding target is adjusted based on estimation of de jure population. ${ }^{6}$ Consolidated budget operations. ${ }^{7}$ As end of the year. ${ }^{8}$ The PRSP projected only de facto population: $3,013.8$ thousand people. 
Annex 2. Breakdown of gross domestic product by main sector

\begin{tabular}{|c|c|c|c|c|}
\hline & \multirow[t]{2}{*}{2002} & \multirow[t]{2}{*}{2003} & \multicolumn{2}{|c|}{2004} \\
\hline & & & PRSP & Prelim. \\
\hline & \multicolumn{4}{|c|}{ in billions of drums, current prices } \\
\hline Gross domestic product & $1,362.5$ & 1624.6 & 1609.4 & 1896.4 \\
\hline Industry & 256.9 & 313.2 & 337.9 & 361.3 \\
\hline Agriculture & 318.8 & 349.2 & 348.9 & 429.4 \\
\hline Construction & 172.2 & 255.4 & 237.9 & 293.7 \\
\hline Transport and communications & 83.6 & 95.7 & 103.8 & 112.9 \\
\hline Trade & 144.1 & 177.7 & 148.3 & 212.4 \\
\hline Others & 255.0 & 285.8 & 270.2 & 327.0 \\
\hline \multirow[t]{2}{*}{ Net Indirect Taxes } & 131.9 & 147.7 & 162.4 & 159.8 \\
\hline & \multicolumn{4}{|c|}{ year-on-year \% change } \\
\hline Gross domestic product & 13.2 & 14.0 & 6.0 & 10.1 \\
\hline Industry & 13.9 & 15.6 & 8.0 & 2.1 \\
\hline Agriculture & 3.8 & 4.2 & 2.8 & 14.5 \\
\hline Construction & 41.5 & 45.5 & -0.4 & 13.4 \\
\hline Transport and communications & -1.7 & 8.3 & 6.0 & 16.9 \\
\hline Trade & 19.7 & 14.1 & 11.4 & 10.5 \\
\hline Others & 12.0 & 8.6 & 6.8 & 12.2 \\
\hline \multirow[t]{2}{*}{ Net Indirect Taxes } & 14.3 & 7.9 & 12.6 & 2.4 \\
\hline & \multicolumn{4}{|c|}{ in $\%$ of $G D P$} \\
\hline Gross domestic product & 100.0 & 100.0 & 100.0 & 100.0 \\
\hline Industry & 18.8 & 19,3 & 21.0 & 19,1 \\
\hline Agriculture & 23.4 & 21,5 & 21.7 & 22,6 \\
\hline Construction & 12.6 & 15,7 & 14.8 & 15,5 \\
\hline Transport and communications & 6.1 & 5,9 & 6.4 & 6,0 \\
\hline Trade & 10.6 & 10,9 & 9.2 & 11,2 \\
\hline Others & 18.7 & 17,6 & 16.8 & 17,2 \\
\hline \multirow[t]{2}{*}{ Net Indirect Taxes } & 9.7 & 9,1 & 10.1 & 8,4 \\
\hline & \multicolumn{4}{|c|}{ contribution to GDP growth, percentage points } \\
\hline Gross domestic product & 13.2 & 14.0 & 6.0 & 10.1 \\
\hline Industry & 2.8 & 2.9 & 1.7 & 0.4 \\
\hline Agriculture & 1.0 & 1.0 & 0.6 & 3.1 \\
\hline Construction & 4.0 & 5.7 & -0.1 & 2.1 \\
\hline Transport and communications & -0.1 & 0.5 & 0.4 & 1.0 \\
\hline Trade & 2.0 & 1.5 & 1.1 & 1.1 \\
\hline Others & 2.1 & 1.6 & 1.1 & 2.2 \\
\hline Net Indirect Taxes & 1.4 & 0.8 & 1.2 & 0.2 \\
\hline
\end{tabular}

Source: National Statistical Service of the Republic of Armenia and PRSP projections. 
Annex 3. Use of gross domestic product

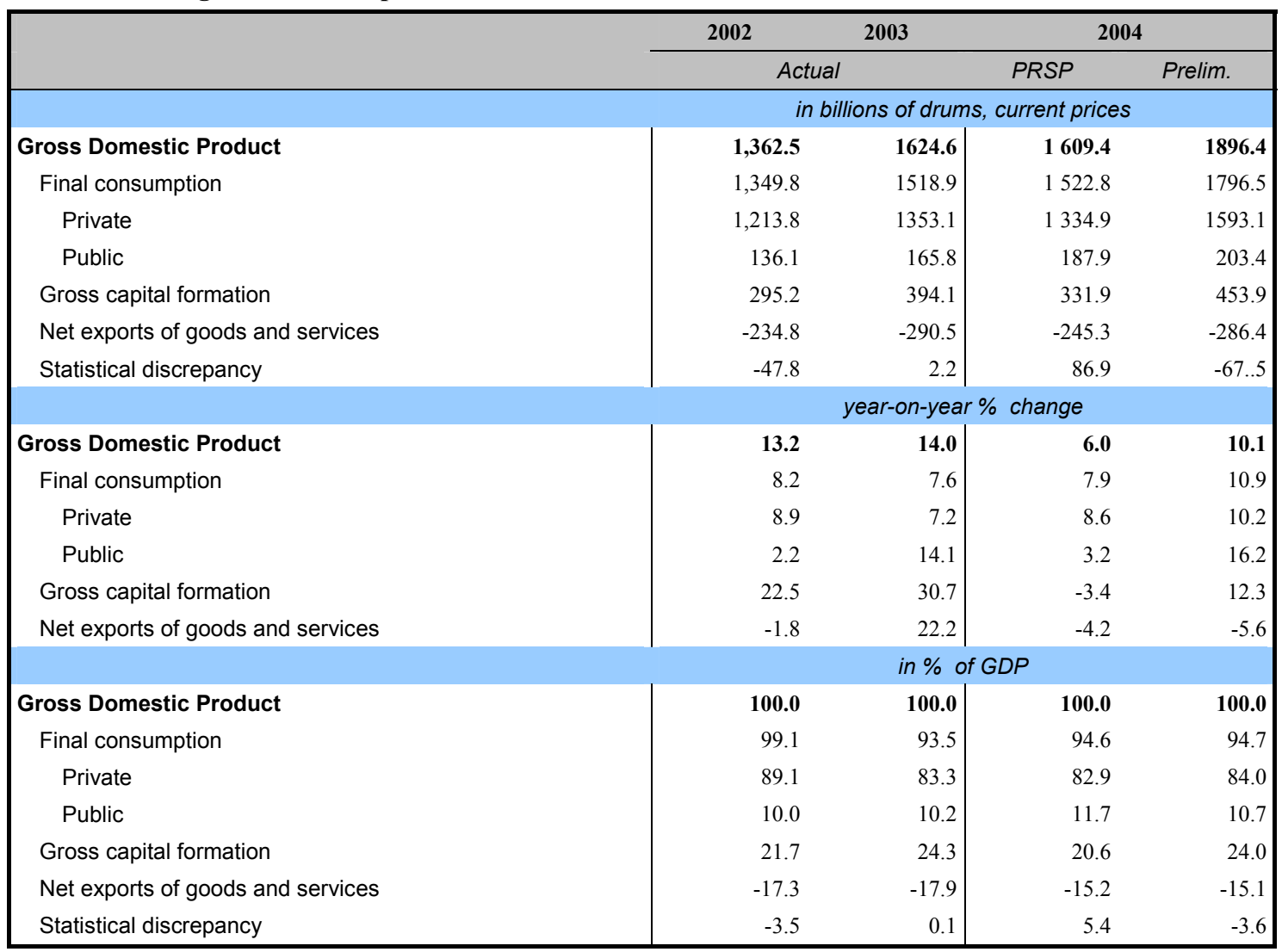

Source: National Statistical Service of the Republic of Armenia and PRSP projections. 
Annex 4. Consolidated budget operations (on a commitment basis)

\begin{tabular}{|c|c|c|c|c|}
\hline & \multirow[t]{2}{*}{2002} & 2003 & \multicolumn{2}{|c|}{2004} \\
\hline & & & PRSP & Prelim. \\
\hline & \multicolumn{4}{|c|}{ in billions of drums } \\
\hline Total revenues and grants & 305.6 & 348.9 & 346.2 & 368.6 \\
\hline Total revenues & 258.1 & 297.4 & 312.9 & 354.8 \\
\hline Tax revenue & 242.3 & 279.3 & 302.2 & 326.1 \\
\hline Non-tax revenue & 15.7 & 18 & 10.7 & 28.7 \\
\hline \multicolumn{5}{|l|}{ Capital revenue } \\
\hline Grants & 47.5 & 51.5 & 33.3 & 13.7 \\
\hline Current & 17.1 & 11.6 & 9.7 & 13.7 \\
\hline Capital & 30.5 & 39.9 & 23.7 & 0.0 \\
\hline Total expenditures and net Lending & 317.7 & 363.3 & 388.1 & 399.8 \\
\hline Current expenditures & 243.5 & 271.5 & 294.0 & 323.9 \\
\hline of which: interest payments & 15.7 & 11.4 & 12.6 & 9.8 \\
\hline Capital expenditures & 63.8 & 85.2 & 86.9 & 65.4 \\
\hline of which: capital grant financed & 30.5 & 39.9 & 23.7 & - \\
\hline Net lending & 10.4 & 6.6 & 7.2 & 10.5 \\
\hline Overall balance & -12.1 & -14.4 & -41.9 & -31.2 \\
\hline Financing & 12.1 & 14.4 & 41.9 & 31.2 \\
\hline Domestic sources & -24.7 & -24.4 & 2.7 & -3.1 \\
\hline \multirow[t]{2}{*}{ External sources } & 36.7 & 38.8 & 39.2 & 34.3 \\
\hline & \multicolumn{4}{|c|}{ in $\%$ of $G D P$} \\
\hline Total revenues and grants & 22.4 & 21.5 & 21.5 & 19.4 \\
\hline Total revenues & 18.9 & 18.3 & 19.4 & 18.7 \\
\hline Tax revenue & 17.8 & 17.2 & 18.8 & 17.2 \\
\hline Non-tax revenue & 22.4 & 21.5 & 21.5 & 19.4 \\
\hline \multicolumn{5}{|l|}{ Capital revenue } \\
\hline Grants & 3.5 & 3.2 & 2.1 & 0.7 \\
\hline Current & 1.3 & 0.7 & 0.6 & 0.7 \\
\hline Capital & 2.2 & 2.5 & 1.5 & 0.0 \\
\hline Total expenditures and net Lending & 23.3 & 22.4 & 24.1 & 21.1 \\
\hline Current expenditures & 17.9 & 16.7 & 18.3 & 17.1 \\
\hline of which: interest payments & 1.2 & 0.7 & 0.8 & 0.5 \\
\hline Capital expenditures & 4.7 & 5.2 & 5.4 & 3.4 \\
\hline of which: capital grant financed & 2.2 & 2.5 & 1.5 & - \\
\hline Net lending & 0.8 & 0.4 & 0.4 & 0.6 \\
\hline Overall balance & -0.9 & -0.9 & -2.6 & -1.6 \\
\hline Financing & 0.9 & 0.9 & 2.6 & 1.6 \\
\hline Domestic sources & -1.8 & -1.5 & 0.2 & -0.2 \\
\hline External sources & 2.7 & 2.4 & 2.4 & 1.8 \\
\hline \multicolumn{5}{|l|}{ Memorandum items } \\
\hline Social expenditures ${ }^{1}, \%$ of GDP & 7.8 & 7.9 & 9.3 & 8.4 \\
\hline Primary balance ${ }^{2}, \%$ of GDP & 0.3 & -0.2 & -1.8 & -1.1 \\
\hline
\end{tabular}

${ }_{1}^{1}$ Includes expenditures on education, health care, social security and social insurance.

${ }^{2}$ Defined as overall balance, excluding interest payments.

Source: Ministry of Finance and Economy of the Republic of Armenia, State Social Insurance Fund of the Republic of Armenia, and PRSP projections. 
Annex 5. Consolidated budget operations: external financing requirements

\begin{tabular}{|c|c|c|c|c|}
\hline & \multirow[t]{2}{*}{2002} & \multirow[t]{2}{*}{2003} & \multicolumn{2}{|c|}{2004} \\
\hline & & & PRSP & Prelim. \\
\hline & \multicolumn{4}{|c|}{ in billions of drums } \\
\hline 1. Total domestic revenues & 258.1 & 297.4 & 312.9 & 354.8 \\
\hline Tax revenue & 242.3 & 279.3 & 302.2 & 326.1 \\
\hline Non-tax and capital revenue & 15.7 & 18.0 & 10.7 & 28.7 \\
\hline 2. Domestic financing & -24.7 & -24.4 & 2.7 & -3.1 \\
\hline 3. Total domestic resources available $(1+2)$ & 233.4 & 273.0 & 315.6 & 351.7 \\
\hline 4. Total expenditures and net lending & 317.7 & 363.3 & 388.1 & 399.8 \\
\hline Current expenditures & 243.5 & 271.5 & 294.0 & 323.9 \\
\hline of which: interest payments & 15.7 & 11.4 & 12.6 & 9.8 \\
\hline Capital expenditures & 63.8 & 85.2 & 86.9 & 65.4 \\
\hline Net lending & 30.5 & 6.6 & 7.2 & 10.5 \\
\hline 5. External financing requirements (4-2) & 84.3 & 90.3 & 72.5 & 48.1 \\
\hline Grants & 47.5 & 51.5 & 33.3 & 13.7 \\
\hline Current & 17.1 & 11.6 & 9.7 & 13.7 \\
\hline Capital & 30.5 & 39.9 & 23.7 & 0.0 \\
\hline \multirow[t]{2}{*}{ Loans/Credits } & 36.7 & 38.4 & 39.2 & 34.9 \\
\hline & \multicolumn{4}{|c|}{ in millions of US dollars } \\
\hline 1. Total domestic revenues & 450,1 & 513,8 & 531.0 & 665,0 \\
\hline Tax revenue & 422,6 & 482,6 & 512.8 & 611,2 \\
\hline Non-tax and capital revenue & 27,4 & 31,1 & 18.2 & 53,8 \\
\hline 2. Domestic financing & -43.1 & $-42,2$ & 4.6 & $-5,8$ \\
\hline 3. Total domestic resources available $(1+2)$ & 407,0 & 471,7 & 535.6 & 659,2 \\
\hline 4. Total expenditures and net lending & 554,1 & 627,7 & 658.6 & 749,4 \\
\hline Current expenditures & 424,7 & 469,1 & 499.0 & 607,1 \\
\hline of which: interest payments & 27,4 & 19,7 & 21.4 & 18,4 \\
\hline Capital expenditures & 111,3 & 147,2 & 147.4 & 122,6 \\
\hline Net lending & 53,2 & 11,4 & 12.2 & 19,7 \\
\hline 5. External financing requirements (4-2) & 147,0 & 156,0 & 123.1 & 90,2 \\
\hline Grants & 82,8 & 89,0 & 56.5 & 25,7 \\
\hline Current & 29,8 & 20,0 & 16.4 & 25,7 \\
\hline Capital & 53,2 & 68,9 & 40.2 & 0,0 \\
\hline \multirow[t]{2}{*}{ Loans/Credits } & 64,0 & 66,3 & 66.5 & 65,4 \\
\hline & \multicolumn{4}{|c|}{ in $\%$ of $G D P$} \\
\hline 1. Total domestic revenues & 18.9 & 18,3 & 19.4 & 18,7 \\
\hline Tax revenue & 17.8 & 17,2 & 18.8 & 17,2 \\
\hline Non-tax and capital revenue & 1.0 & 1,1 & 0.7 & 1,5 \\
\hline 2. Domestic financing & -1.8 & $-1,5$ & 0.2 & $-0,2$ \\
\hline 3. Total domestic resources available $(1+2)$ & 17.1 & 16,8 & 19.6 & 18,5 \\
\hline 4. Total expenditures and net lending & 23.3 & 22,4 & 24.1 & 21,1 \\
\hline Current expenditures & 17.9 & 16,7 & 18.3 & 17,1 \\
\hline of which: interest payments & 1.2 & 0,7 & 0.8 & 0,5 \\
\hline Capital expenditures & 4.7 & 5,2 & 5.4 & 3,4 \\
\hline Net lending & 0.8 & 0,4 & 0.4 & 0,6 \\
\hline 5. External financing requirements (4-2) & 6.2 & 5,6 & 4.5 & 2,5 \\
\hline Grants & 3.5 & 3,2 & 2.1 & 0,7 \\
\hline Current & 1.3 & 0,7 & 0.6 & 0,7 \\
\hline Capital & 2.2 & 2,5 & 1.5 & 0,0 \\
\hline Loans/Credits & 2.7 & 2,4 & 2.4 & 1,8 \\
\hline
\end{tabular}

Source: Ministry of Finance and Economy of the Republic of Armenia, State Social Insurance Fund of the Republic of Armenia, and PRSP projections. 
Annex 6. Consolidated budget expenditure by main functions (on a commitment basis)

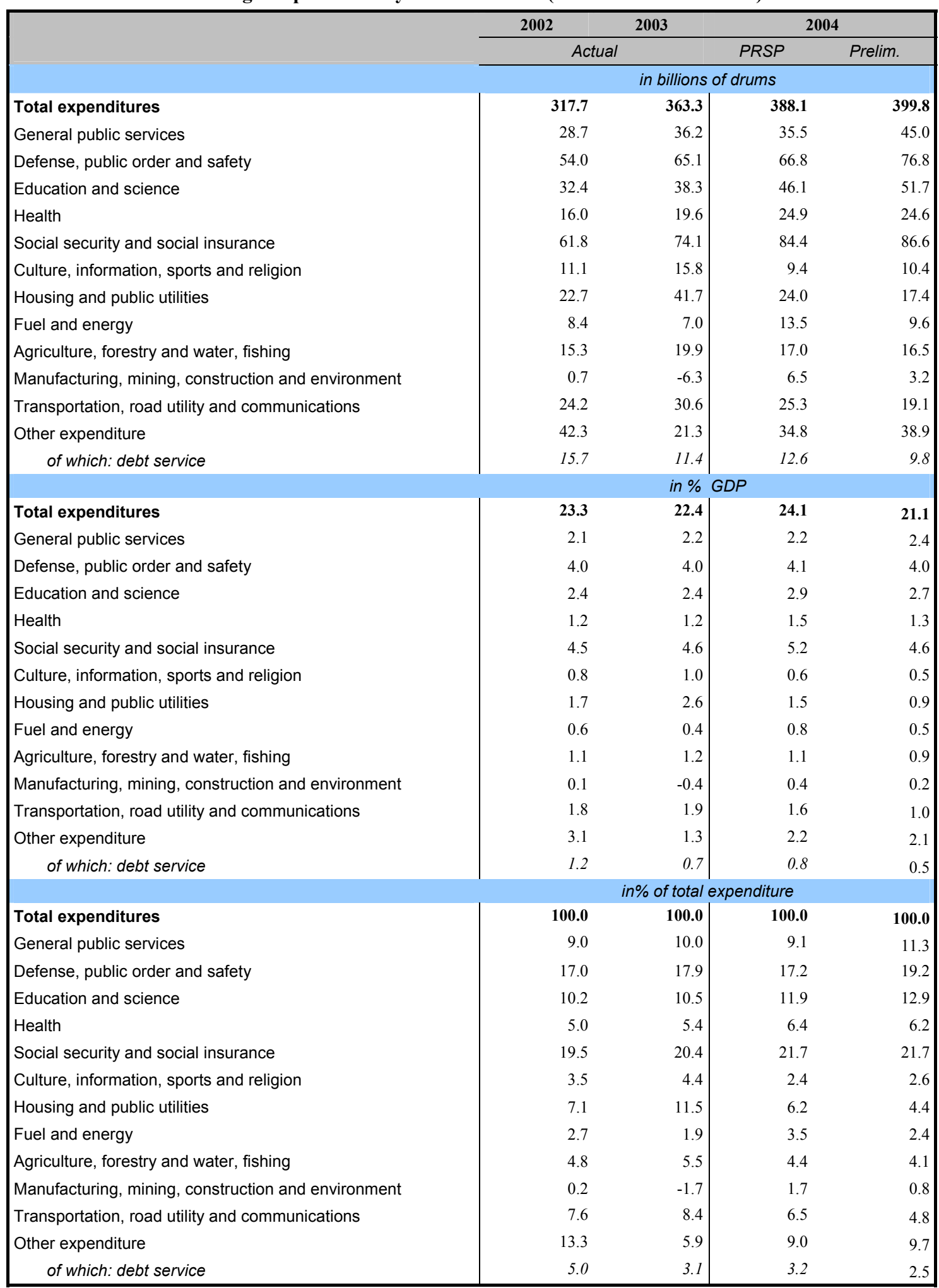

Source: Ministry of Finance and Economy of the Republic of Armenia, State Social Insurance Fund of the Republic of Armenia, and PRSP projections. 
Annex 7. Consolidated budget social expenditures (on a commitment basis)

\begin{tabular}{|c|c|c|c|c|}
\hline & 2002 & 2003 & & \\
\hline & Act & & PRSP & Prelim. \\
\hline & & in billions & drums & \\
\hline Total social expenditures & 106.6 & 127.9 & 150.3 & 157.4 \\
\hline Education & 29.7 & 35.4 & 42.8 & 48.4 \\
\hline Health & 16.0 & 19.6 & 24.9 & 24.6 \\
\hline Social security and social insurance ${ }^{1}$ & 61.0 & 73.0 & 82.6 & 84.4 \\
\hline of which: family benefits & 12.1 & 12.4 & 16.1 & 16.1 \\
\hline & & ear-on-yea & change & \\
\hline Total social expenditures & -1.2 & 20.0 & 17.8 & 23.1 \\
\hline Education & -3.3 & 19.1 & 21.6 & 36.7 \\
\hline Health & -8.1 & 22.6 & 18.6 & 25.5 \\
\hline Social security and social insurance ${ }^{1}$ & 1.9 & 19.7 & 15.8 & 15.6 \\
\hline of which: family benefits & -24.8 & 2.2 & 26.3 & 29.8 \\
\hline & & in $\%$ & & \\
\hline Total social expenditures & 7.8 & 7.9 & 9.3 & 8.3 \\
\hline Education & 2.2 & 2.2 & 2.7 & 2.6 \\
\hline Health & 1.2 & 1.2 & 1.5 & 1.3 \\
\hline Social security and social insurance ${ }^{1}$ & 4.5 & 4.5 & 5.1 & 4.5 \\
\hline of which: family benefits & 0.9 & 0.8 & 1.0 & 0.8 \\
\hline & in $\%$ of & solidated b & yet total exp & liture \\
\hline Total social expenditures & 33.6 & 35.2 & 38.7 & 39.4 \\
\hline Education & 9.3 & 9.7 & 11.0 & 12.1 \\
\hline Health & 5.0 & 5.4 & 6.4 & 6.2 \\
\hline Social security and social insurance ${ }^{1}$ & 19.2 & 20.1 & 21.3 & 21.1 \\
\hline of which: family benefits & 3.8 & 3.4 & 4.1 & 4.0 \\
\hline
\end{tabular}

Excluding expenditures on system maintenance and development.

Source: Ministry of Finance and Economy of the Republic of Armenia, State Social Insurance Fund of the Republic of Armenia, and PRSP projections. 
Annex 8. Armenia: balance of payments

\begin{tabular}{|c|c|c|c|c|}
\hline & \multirow[t]{2}{*}{2002} & 2003 & \multicolumn{2}{|c|}{2004} \\
\hline & & & PRSP & Prelim. \\
\hline & \multicolumn{4}{|c|}{ in millions of US dollars, unless otherwise indicated } \\
\hline Current account & -148 & -189 & -159 & -162 \\
\hline Trade balance & -369 & -434 & -373 & -458 \\
\hline Exports (f.o.b.) & 514 & 696 & 639 & 738 \\
\hline Imports (f.o.b.) & -883 & -1130 & -1012 & -1196 \\
\hline Services (net) & -41 & -68 & -43 & -71 \\
\hline Credits & 184 & 207 & 201 & 247 \\
\hline Debits & -225 & -276 & -244 & -317 \\
\hline Income and private transfers (net) & 207 & 253 & 202 & 306 \\
\hline Official transfers (net) & 55 & 60 & 55 & 61 \\
\hline Capital and financial account & 191 & 194 & 202 & 174 \\
\hline Capital transfers (net) & 68 & 90 & 55 & 34 \\
\hline Foreign direct investments (net) & 111 & 121 & 80 & 217 \\
\hline Portfolio investments (net) & 2 & 0 & 0 & -3 \\
\hline Public sector (net) & 33 & -41 & 67 & 23 \\
\hline Disbursement & 55 & 50 & 80 & 72 \\
\hline Amortization & -21 & -90 & -13 & -49 \\
\hline Other capital (net) & -22 & 24 & 0 & -96 \\
\hline Errors and omissions (net) & -4 & -2 & 42 & -1 \\
\hline Overall balance & 39 & 3 & -159 & 12 \\
\hline \multicolumn{5}{|l|}{ Financing: } \\
\hline Change in gross reserves ('-' increase) & -81 & -47 & -36 & -26 \\
\hline IMF (net) & 7 & 2 & -6 & -6 \\
\hline Financing gap & 35 & 43 & 0 & 21 \\
\hline World Bank & 35 & 43 & 0 & 21 \\
\hline Other & 0 & 0 & 0 & 0 \\
\hline \multicolumn{5}{|l|}{ Memorandum items } \\
\hline Current account (in \% of GDP) & -6.2 & -6.7 & -5.8 & -4.5 \\
\hline excluding official transfers & -8.5 & -8.9 & -7.9 & -6.3 \\
\hline Gross reserves (end of period) & 431 & 504 & 480 & 550 \\
\hline in months of imports & 4.7 & 4.3 & 4.6 & 4.4 \\
\hline Nominal external debt & 1,026 & 1098 & 1104 & 1183 \\
\hline External debt-to-GDP ratio, \% & 43.2 & 39.1 & 40.4 & 33.3 \\
\hline Present value of external debt & 673 & 728 & 623 & 735 \\
\hline Present value of debt-to-GDP ratio, $\%$ & 28.3 & 26 & 22.8 & 21 \\
\hline Present value of debt-to-G\&NFS exports ratio, \% & 96.5 & 81 & 74.2 & 76 \\
\hline
\end{tabular}

Source: National Statistical Service of the Republic of Armenia, Central Bank of the Republic of Armenia, Ministry of Finance and Economy of the Republic of Armenia, and PRSP projections. 
Annex 9. PRSP monitoring indicators

\begin{tabular}{|c|c|c|c|c|c|}
\hline Number & Indicator & 2001 & 2002 & 2003 & 2004 \\
\hline A1 & Number of the poor, percentage of current population & 50.9 & 49.7 & 42.9 & 39.0 \\
\hline $\mathrm{A} 2$ & Number of the extremely poor, percentage of the current population & 16.0 & 13.1 & 7.4 & 7.2 \\
\hline A3 & GDP per capita, thous. AMD, 2001 prices & 365.8 & 414.4 & 472.6 & 520.0 \\
\hline A1_int & $\begin{array}{l}\text { Number of people with less than US\$1 (PPP) consumer expenditures } \\
\text { per day as a percentage of current population }\end{array}$ & 3.4 & 2.1 & 0.1 & 0.5 \\
\hline a1.1 & Wages, percentage of total monetary incomes & 30.6 & 38.0 & 41.2 & 48.5 \\
\hline a1.2 & $\begin{array}{l}\text { Incomes from self-employment, percentage of total monetary } \\
\text { incomes }\end{array}$ & 11.7 & 15.2 & 14.0 & 8.0 \\
\hline a1.3 & $\begin{array}{l}\text { Incomes from sales of agricultural products and livestock, percentage } \\
\text { of total monetary incomes }\end{array}$ & 15.6 & 6.4 & 12.7 & 11.1 \\
\hline a1.4 & $\begin{array}{l}\text { Average monthly salary in social infrastructures sector as a } \\
\text { percentage of general poverty line }\end{array}$ & 103.2 & 112.0 & 130.7 & 177.6 \\
\hline a 1.5 & $\begin{array}{l}\text { Value added in the agricultural sector, the change compared to } \\
\text { previous year in percentages }\end{array}$ & 11.7 & 3.8 & 4.2 & 14.5 \\
\hline a1.6 & Level of commercialization of agricultural production, percentage & 49.9 & 54.1 & 58.9 & 55.7 \\
\hline a1.7 & Agricultural credits, percentage of agricultural added value & 9398.0 & 7787.0 & 8152.0 & 8611.0 \\
\hline a1.8 & $\begin{array}{l}\text { Expenditures form the consolidated budget in the agricultural sector, } \\
\text { million AMD }\end{array}$ & 17019.3 & 14466.1 & 19855.7 & 16473.8 \\
\hline a1.9 & Capital public expenditures in the irrigation sector, million AMD & 6162.7 & 5907.5 & 6212.5 & 4348.3 \\
\hline a1.10 & $\begin{array}{l}\text { Expenditures form the consolidated budget in the roads system, } \\
\text { million AMD/km }\end{array}$ & 0.477 & 0.668 & 2.620 & 1.663 \\
\hline a1.10(i) & maintenance expenditures, million AMD/km & 0.011 & 0.137 & 0.237 & 0.323 \\
\hline a1.10(ii) & capital repair expenditures, million $A M D / \mathrm{km}$ & 0.466 & 0.530 & 2.383 & 1.341 \\
\hline a1.11 & $\begin{array}{l}\text { Expenditures form the consolidated budget in the rural roads } \\
\text { construction sector, million AMD } / \mathrm{km}\end{array}$ & & & & \\
\hline a1.11(i) & maintenance expenditures, million AMD/km & - & - & - & \\
\hline a1.11(ii) & capital repair expenditures, million $A M D / k m$ & - & - & - & \\
\hline a1.12 & Number of personal vehicles registered & 176000 & 183000 & 195000 & 208000 \\
\hline a1.13(i) & $\begin{array}{l}\text { Expected number of years of study (in the period of 6-21 years of } \\
\text { age), years }\end{array}$ & & & 11.4 & \\
\hline a1.13(ii) & $\begin{array}{l}\text { Public expenditures in education and healthcare sectors, percentage } \\
\text { of overall non-interest rate expenditures of the consolidated budget }\end{array}$ & 16.3 & 15.0 & 15.6 & 18.8 \\
\hline a1.13(iii) & Number of computers, per 1000 people & - & 2.9 & 5.8 & 9.3 \\
\hline a1.13(iv) & Number of internet users, per 1000 people & & & & \\
\hline $\mathrm{a} 1.13(\mathrm{v})$ & Availability of internet in libraries, share in percentage & 0.70 & 0.72 & 0.73 & 0.64 \\
\hline a1.14(i) & $\begin{array}{l}\text { Average time spent by enterprises for obtaining state registration, } \\
\text { days }\end{array}$ & 15.6 & 14.5 & 18.6 & 16 \\
\hline a1.14(ii) & Average time spent for obtaining licenses, days & 21.3 & 13.7 & 20.1 & 16.5 \\
\hline a1.14(iii) & Number of procedures for registering property & 2 & 2 & 2 & \\
\hline a1.14(iv) & Average time spent by enterprises with regard to inspections, days & 18.6 & 13.8 & 15.5 & 14.0 \\
\hline
\end{tabular}




\begin{tabular}{|c|c|c|c|c|c|}
\hline Number & Indicator & 2001 & 2002 & 2003 & 2004 \\
\hline $\mathrm{a} 1.14(\mathrm{v})$ & Number of commercial organizations per 1000 people & t & - & - & \\
\hline a1.14(vi) & Competition policy (index) & & - & 2 & 2 \\
\hline a1.14(vii) & Banking reforms and interest rate liberalization (index) & & & $2+$ & $2+$ \\
\hline a1.14(viii) & Securities market and non-bank financial institutions (index) & & & 2 & 2 \\
\hline a2.1 & Gini coefficient for income concentration & 0.528 & 0.449 & 0.434 & 0.387 \\
\hline $\mathrm{a} 2.2$ & Gini coefficient for spending concentration & 0.344 & 0.325 & 0.271 & 0.308 \\
\hline a2.3 & $\begin{array}{l}\text { Ratio of the incomes of the richest (upper } 20 \text { percent) segment of the } \\
\text { population to the poorest (lower } 20 \text { percent) segment of the } \\
\text { population, percentage }\end{array}$ & & & 13.3 & 10.6 \\
\hline a2.4 & Average monthly old-age pension, percentage of general poverty line & 38.1 & 46.9 & 59.0 & 59.4 \\
\hline $\mathrm{a} 2.5$ & Average monthly social pension, percentage of poverty food line & 45.9 & 46.9 & 46.0 & 39.7 \\
\hline a2.6 & $\begin{array}{l}\text { Public expenditures in the social security sector, percentage of } \\
\text { overall non-interest rate expenditures of the consolidated budget, } \\
\text { percentage }\end{array}$ & 7.0 & 5.4 & 5.3 & 5.8 \\
\hline $\mathrm{a} 2.7$ & $\begin{array}{l}\text { Expenditures from the consolidated budget on old-age pension, } \\
\text { percentage of GDP }\end{array}$ & 2.8 & 2.7 & 2.8 & 2.8 \\
\hline a2.8 & State budget expenditures on family benefits, percentage of GDP & 1.4 & 0.9 & 0.8 & 0.9 \\
\hline a2.9 & $\begin{array}{l}\text { State budget expenditures on family benefits, percentage of poverty } \\
\text { gap (characterized by depth) }\end{array}$ & 43.5 & 38.5 & 67.1 & 73.5 \\
\hline a2.10 & $\begin{array}{l}\text { Incomes from pensions and benefits, percentage of total monetary } \\
\text { incomes }\end{array}$ & 9.6 & 11.5 & 9.9 & 13.6 \\
\hline $\mathrm{a} 2.11$ & $\begin{array}{l}\text { Coefficient of concentration of public expenditures in the education } \\
\text { sector }\end{array}$ & & & & \\
\hline a2.12 & $\begin{array}{l}\text { Coefficient of concentration of public expenditures in the healthcare } \\
\text { sector }\end{array}$ & & & & \\
\hline B1(i) & $\begin{array}{l}\text { Expected number of years of study (in the period of 6-21 years of } \\
\text { age), years }\end{array}$ & & & 11.4 & \\
\hline B1(ii) & Gross enrollment in basic school, percentage & 90.8 & 90.5 & 89.5 & \\
\hline B1(iii) & Coefficient of concentration of enrollment in senior school & & & & \\
\hline B2(i) & $\begin{array}{l}\text { Results of the national system to be introduced for assessing the } \\
\text { quality of education }\end{array}$ & & & & \\
\hline B2(ii) & $\begin{array}{l}\text { Level of satisfaction of students' parents with the quality of services } \\
\text { provided at formal basic education level }\end{array}$ & 19.8 & & & \\
\hline B2(iii) & Level of the spread of enrollment in private tutoring classes & 63 & & & \\
\hline b1.1 & Expenditures from the consolidated budget on format basic education & 19877 & 18460 & 23087 & 34396 \\
\hline b1.1(i) & percentage of total expenditures & 6.9 & 5.8 & 6.4 & 8.6 \\
\hline b1.1(ii) & percentage of $G D P$ & 1.7 & 1.4 & 1.4 & 1.8 \\
\hline b1.1(iii) & per student as percentage of GDP per capita & 10.1 & 8.4 & 9.2 & 12.1 \\
\hline b1.2 & $\begin{array}{l}\text { Capital expenditures from the consolidated budget on formal basic } \\
\text { education, as percentage of total expenditures on formal basic } \\
\text { education }\end{array}$ & 14.3 & 4.3 & 9.2 & 17.4 \\
\hline
\end{tabular}




\begin{tabular}{|c|c|c|c|c|c|}
\hline Number & Indicator & 2001 & 2002 & 2003 & 2004 \\
\hline b2.1 & $\begin{array}{l}\text { Number of teachers with professional qualifications, as a percentage } \\
\text { of the total number of teachers }\end{array}$ & 91.4 & 91.8 & 93.3 & \\
\hline $\mathrm{b} 2.2$ & Number of teachers who participated in training courses & & & 22.7 & \\
\hline $\mathrm{b} 2.3$ & Average salary of teachers & 12609 & 15388 & 18591 & 30681 \\
\hline b2.3(i) & AMD/month & 12609 & 15388 & 18591 & 30681 \\
\hline b2.3(ii) & percentage of GDP per capita & 41.3 & 52.1 & 44.7 & 62.5 \\
\hline b2.3(iii) & real (CPI adjusted) change compared to previous year & & 120.7 & 115.4 & 154.2 \\
\hline b2.4(iv) & percentage of general poverty line & 104.9 & 125.5 & 147.2 & 210.2 \\
\hline b3.1 & $\begin{array}{l}\text { Expenditures on repair of formal basic education schools, million } \\
\text { AMD }\end{array}$ & 54 & 453 & 481 & 4511 \\
\hline b3.2 & Number of repaired schools & 94 & 97 & 84 & 376 \\
\hline b3.3 & Number of schools having local heating systems & & 119 & 134 & \\
\hline b3.3(i) & $\begin{array}{l}\text { Number of students studying in schools with local heating systems, } \\
\text { percentage of total number of students }\end{array}$ & & 9.3 & 10.8 & \\
\hline b4.1 & $\begin{array}{l}\text { Public expenditures on methodological and material-technical } \\
\text { provisions, million AMD }\end{array}$ & & & & \\
\hline $\mathrm{b} 4.2$ & $\begin{array}{l}\text { Number of computers in formal basic education schools, per } 1000 \\
\text { students }\end{array}$ & & 8.0 & 6.8 & \\
\hline $\mathrm{b} 4.3$ & Number of schools with computer classes & - & 1536 & 1364 & \\
\hline $\mathrm{b} 4.4$ & Number of schools with internet connection & - & - & 155 & \\
\hline b5.1 & Student / teacher ratio in formal basic education & 11.4 & 11.2 & 11 & 13.2 \\
\hline b5.2 & Student / non-teacher ratio in formal basic education & 19.4 & 18.8 & 21.2 & 19.7 \\
\hline b5.3 & Average density of classes & 20.0 & 20.0 & 21.0 & \\
\hline b5.3(i) & elementary school & 20.0 & 19.4 & 20.2 & \\
\hline b5.3(ii) & secondary school & 21.0 & 20.8 & 22.1 & \\
\hline b5.3(iii) & senior school & 19.0 & 18.7 & 19.7 & \\
\hline B1(ii)_s1 & Gross enrollment in senior school, percentage & 71.8 & 74.9 & 76.3 & \\
\hline B1(ii)_s2 & $\begin{array}{l}\text { Number of secondary school graduates as a percentage of the number } \\
\text { of children enrolled in the first grade in the corresponding year }\end{array}$ & 76.8 & 66.5 & 67.9 & \\
\hline B2(i)_int & Results of international studies on the quality of education & & & & \\
\hline $\mathrm{C} 1(\mathrm{i})$ & $\begin{array}{l}\text { Average number of annual visits per person to prophylactic } \\
\text { healthcare facilities providing ambulatory polyclinic medical services }\end{array}$ & 1.8 & 1.9 & 2.0 & 2.0 \\
\hline $\mathrm{C} 1$ (ii) & $\begin{array}{l}\text { Coefficient of polarization of the frequency of visits paid by patients } \\
\text { to healthcare facilities }\end{array}$ & & & & \\
\hline $\mathrm{C} 1$ (iii) & $\begin{array}{l}\text { Those visiting primary healthcare facilities in the total number of the } \\
\text { poor, percentage of the total number of the poor visiting healthcare } \\
\text { facilities }\end{array}$ & & & & \\
\hline $\mathrm{C} 2(\mathrm{i})$ & U-5 mortality per 1000 live births & 18.7 & 16.7 & 13.6 & 13.0 \\
\hline
\end{tabular}




\begin{tabular}{|c|c|c|c|c|c|}
\hline Number & Indicator & 2001 & 2002 & 2003 & 2004 \\
\hline C2(ii) & Maternal mortality per 100000 live births (three-year average) & & & & \\
\hline & NSS & 34.0 & 27.4 & 17.0 & \\
\hline & $\mathrm{MoH}$ & 43.3 & 37.8 & 20.2 & 24.9 \\
\hline C3(i) & $\begin{array}{l}\text { Population's morbidity with active tuberculosis, cases per } 100000 \\
\text { people }\end{array}$ & 35.4 & 43.4 & 44.7 & 48.5 \\
\hline C3(ii) & Population's morbidity with malaria, cases per 10000000 people & 2.07 & 1.60 & 0.90 & 1.50 \\
\hline C3(iii) & $\begin{array}{l}\text { Population's morbidity with sexually transmitted diseases, cases per } \\
100000 \text { people }\end{array}$ & 34.4 & 35.1 & 27.5 & 26.0 \\
\hline C3(iv) & Spread of HIV, the number of infected per 100000 people & 0.83 & 1.28 & 0.90 & 1.52 \\
\hline $\mathrm{c} 1.1$ & Expenditures from the consolidated budget on healthcare & 15746 & 15968 & 19603 & 24694 \\
\hline c1.1(i) & percentage of total budget expenditures & 5.4 & 5.0 & 5.4 & 6.2 \\
\hline c1.1(ii) & percentage of $G D P$ & 1.3 & 1.2 & 1.2 & 1.3 \\
\hline c1.1(iii) & US\$ per capita & 8.8 & 8.7 & 10.5 & 14.4 \\
\hline $\mathrm{c} 1.2$ & $\begin{array}{l}\text { Expenditures from the consolidated budget on primary healthcare, } \\
\text { percentage of total budget expenditures on healthcare }\end{array}$ & 19.1 & 21.2 & 33.2 & 32.3 \\
\hline $\mathrm{c} 1.3$ & $\begin{array}{l}\text { Capital expenditures from the consolidated budget on healthcare, } \\
\text { percentage of total budget expenditures on healthcare }\end{array}$ & 13.9 & 7.7 & 6.2 & 6.0 \\
\hline $\mathrm{c} 2.1$ & Average salary of doctors at primary healthcare level & & & & \\
\hline $\mathrm{c} 2.1(\mathrm{i})$ & AMD/month & 24000 & 25000 & 27700 & 36000 \\
\hline c2.1(ii) & percentage of GDP per capita & 73.6 & 73.7 & 65.8 & 95.5 \\
\hline c2.1(iii) & real (CPI adjusted) change compared to previous year & 94.0 & 3.0 & 5.8 & 21.5 \\
\hline c2.1(iv) & percentage of average salary of doctors in hospitals & 126.3 & 131.5 & 110.8 & 107.5 \\
\hline $\mathrm{c} 2.2$ & Average salary of mid-level medical staff at primary healthcare level & & & & \\
\hline c2.2(i) & AMD/month & 15000 & 16000 & 17700 & 26000 \\
\hline c2.2(ii) & percentage of GDP per capita & 58.2 & 53.5 & 42 & 69.2 \\
\hline c2.2(iii) & real (CPI adjusted) change compared to previous year & 94.0 & 5.5 & 5.7 & 37.3 \\
\hline c2.2(iv) & $\begin{array}{l}\text { percentage of average salary of mid-level medical staff in } \\
\text { hospitals }\end{array}$ & 105.9 & 107.1 & 114.3 & 110.6 \\
\hline c3.1 & Availability of basic equipment in marz hospitals & & & & \\
\hline c3.2 & Number of rural medical ambulatories repaired (newly built) & & & & \\
\hline $\mathrm{c} 3.3$ & Number of rural medical ambulatories having local heating systems & & & & \\
\hline c3.3(i) & $\begin{array}{l}\text { Number of people receiving services at rural medical ambulatories } \\
\text { with local heating systems, percentage of the total number of rural } \\
\text { population }\end{array}$ & & & & \\
\hline c4.1 & Births under qualified medical supervision, percentage & 98.4 & 98.7 & 99.2 & 99.5 \\
\hline
\end{tabular}




\begin{tabular}{|c|c|c|c|c|c|}
\hline Number & Indicator & 2001 & 2002 & 2003 & 2004 \\
\hline $\mathrm{c} 4.2$ & $\begin{array}{l}\text { Share of women of reproductive age who receive at least one medical } \\
\text { examination per year, percentage }\end{array}$ & & & & \\
\hline $\mathrm{c} 4.3$ & Contraceptive Prevalence Rate, percentage & 3.3 & 2.6 & 1.7 & 1.6 \\
\hline $\mathrm{c} 4.4$ & $\begin{array}{l}\text { Number of healthcare facilities providing Emergency Obstetric Care, } \\
\text { per } 500000 \text { people }\end{array}$ & 8 & 9 & 9 & 9 \\
\hline $\mathrm{c} 4.5$ & Expenditures on obstetric-gynecological care & & & & \\
\hline $\mathrm{c} 4.5(\mathrm{i})$ & percentage of budget expenditures on healthcare & & & - & \\
\hline c4.5(ii) & per patient, thousand $A M D$ & - & - & - & \\
\hline & hospital care level & & - & - & \\
\hline & primary healthcare level & - & - & - & \\
\hline $\mathrm{c} 4.6$ & Immunization coverage by diseases, percentage & & & & \\
\hline c4.6(i) & Diphtheria, polio (infants under 1 year of age) & 94.5 & 93.4 & 93.8 & 93.5 \\
\hline c4.6(ii) & Whooping cough (infants under 1 year of age) & 93.7 & 91.3 & 93.8 & 92.8 \\
\hline c4.6(iii) & Measles (1 year-old children) & 95.6 & 78.3 & 93.8 & 93.8 \\
\hline c4.6(iv) & Tuberculosis (infants under 1 year of age) & 96.4 & 97.1 & 92.1 & 95.8 \\
\hline $\mathrm{c} 5.1$ & $\begin{array}{l}\text { Share of cases of tuberculosis diagnosed and treated during directly } \\
\text { observed treatment, short-course (DOTS) }\end{array}$ & & & & \\
\hline $\mathrm{c} 5.2$ & Spread of HIV among pregnant women aged 15-24 & & & - & \\
\hline c5.3 & $\begin{array}{l}\text { Share of those using condoms among users of various kinds of } \\
\text { contraception }\end{array}$ & & & & \\
\hline c6.1 & Average annual duration of occupation of hospital beds, days & 136 & 153 & 164 & 170 \\
\hline D1(i) & $\begin{array}{l}\text { Share of people having sustainable access to safe drinking water, } \\
\text { percentage }\end{array}$ & & 94.8 & 94.1 & 95.4 \\
\hline D1(ii) & Average daily duration of water supply, hours & & & - & \\
\hline D1(iii) & Share of households using springs (and/or wells, rivers), percentage & & 3.6 & 2.9 & 3.8 \\
\hline D1(iv) & $\begin{array}{l}\text { Share of households using water delivered by water tankers, } \\
\text { percentage }\end{array}$ & & 5.2 & 5.9 & 4.6 \\
\hline D2(i) & Number of people living in overcrowded houses, per 1000 people & & & & \\
\hline D2(ii) & $\begin{array}{l}\text { Number of people living in shacks or temporary dwellings, per } 1000 \\
\text { people }\end{array}$ & & 34 & 49 & 37 \\
\hline D2(iii) & Number of families living in unsafe dwellings, per 1000 people & 30 & 30 & 40 & 40 \\
\hline D3(i) & Communication density, per 1000 people & 160 & 170 & 180 & 193 \\
\hline D3(ii) & $\begin{array}{l}\text { Level of digitalization of phone connections, share in the total } \\
\text { number of subscribers }\end{array}$ & 20.0 & 24.2 & 33.4 & \\
\hline D3(iii) & $\begin{array}{l}\text { Access to TV programs, percentage of population having access to } \\
\text { more than one TV channel }\end{array}$ & 96.16 & 97.10 & 97.17 & 93.70 \\
\hline
\end{tabular}




\begin{tabular}{|c|c|c|c|c|c|}
\hline Number & Indicator & 2001 & 2002 & 2003 & 2004 \\
\hline $\mathrm{d} 1.1$ & Construction of new pipeleines, $\mathrm{km}$ & 0.0 & 3.1 & 14.5 & 22.1 \\
\hline $\mathrm{d} 1.2$ & Repair of water pipelines, $\mathrm{km}$ & 5.1 & 4.3 & 38.9 & 22.1 \\
\hline $\mathrm{d} 1.3$ & Level of fee collection, percentage & 67.7 & 42.8 & 127.5 & 72.4 \\
\hline $\mathrm{d} 1.4$ & $\begin{array}{l}\text { Level of recording of the volume of water supplied to end users, } \\
\text { percentage of users with water meters }\end{array}$ & 3.2 & 5.8 & 48.3 & 67.6 \\
\hline $\mathrm{d} 1.5$ & Water losses in networks, percentage & 65.8 & 68.0 & 73.3 & 79.5 \\
\hline $\mathrm{d} 2.1$ & $\begin{array}{l}\text { Number of people living on less than } 9 \text { sq. meter living area, per } \\
1000 \text { people }\end{array}$ & & & & \\
\hline $\mathrm{d} 2.2$ & Number of houses per 1000 people & 950 & 970 & 980 & 980 \\
\hline $\mathrm{d} 2.3$ & $\begin{array}{l}\text { Number of people living in buildings with risk of accidents } \\
\text { classified as grade } 3 \text { or higher, per } 1000 \text { people }\end{array}$ & 30 & 30 & 40 & 35 \\
\hline $\mathrm{d} 2.4$ & Number of new houses delivered & 1700 & 2800 & 4700 & 3060 \\
\hline $\mathrm{d} 2.5$ & $\begin{array}{l}\text { Level of state assistance, number of people receiving state assistance } \\
\text { per } 1000 \text { people }\end{array}$ & & 2.0 & 2.4 & 3.0 \\
\hline $\mathrm{d} 2.6$ & $\begin{array}{l}\text { Number of families living in houses in landslide zones, per } 1000 \\
\text { families }\end{array}$ & 0.4 & 0.4 & 0.3 & 0.8 \\
\hline $\mathrm{d} 3.1$ & Investments in telecommunications, million AMD & 11.4 & 14.9 & 17.1 & 19.6 \\
\hline E1 & Freedom of the press, rank & 27 & 24 & 30 & 31 \\
\hline E2 & Regulatory quality, rank & & 3 & - & 8 \\
\hline E3 & Government effectiveness (executive branch), rank & & 15 & - & 17 \\
\hline E4 & Rule of law, rank & - & 17 & - & 22 \\
\hline E5 & Corruption perceptions index, rank & - & 20 & 16 & 12 \\
\hline $\mathrm{e} 1.1$ & $\begin{array}{l}\text { Average salary of public servants, percentage of the average salary of } \\
\text { senior staff in private non-agricultural sector }\end{array}$ & & & & \\
\hline $\mathrm{e} 1.2$ & $\begin{array}{l}\text { Average salary of employees in the judiciary system, percentage of } \\
\text { average salary of employees in private law firms }\end{array}$ & & & & \\
\hline $\mathrm{e} 1.3$ & $\begin{array}{l}\text { Average salary of employees in tax and customs authorities, } \\
\text { percentage of the average salary of senior staff in private non- } \\
\text { agricultural sector }\end{array}$ & & & & \\
\hline $\mathrm{e} 2.1$ & Tax revenues of the state budget, percentage of GDP & 14.4 & 14.6 & 14 & 14.1 \\
\hline $\mathrm{e} 2.2$ & $\begin{array}{l}\text { Deposits in the banking system, changes compared to previous year, } \\
\text { percentage }\end{array}$ & 1.3 & 23.4 & 23.6 & 32.2 \\
\hline $\mathrm{e} 2.3$ & $\begin{array}{l}\text { The average per capita consumption gap based on national accounts } \\
\text { and household surveys }\end{array}$ & & & & \\
\hline $\mathrm{e} 2.4$ & $\begin{array}{l}\text { Increase in average salary (income tax base), percentage compared to } \\
\text { previous year }\end{array}$ & 10.6 & 9.2 & 22.3 & 15.9 \\
\hline $\mathrm{e} 2.5$ & $\begin{array}{l}\text { Non-formal payments in the healthcare system, percentage of } \\
\text { expenditures on healthcare (household survey) }\end{array}$ & & & & \\
\hline $\mathrm{e} 2.6$ & $\begin{array}{l}\text { Non-formal payments in the educational system, percentage of } \\
\text { expenditures on education (household survey) }\end{array}$ & & & & \\
\hline $\mathrm{e} 2.7$ & $\begin{array}{l}\text { Non-formal payments in healthcare and educational system, } \\
\text { percentage of total expenditures (household survey) }\end{array}$ & & & & \\
\hline
\end{tabular}




\begin{tabular}{|c|c|c|c|c|c|}
\hline Number & Indicator & 2001 & 2002 & 2003 & 2004 \\
\hline e3.1 & $\begin{array}{l}\text { Number of TV broadcast hours devoted to the coverage and } \\
\text { interpretation of state policies }\end{array}$ & 2.7 & 4.0 & 3.3 & \\
\hline e3.2 & Open public discussions on draft laws, percentage & - & - & 100 & 100 \\
\hline $\mathrm{e} 3.3$ & $\begin{array}{l}\text { Number of press conferences on the operations of governmental } \\
\text { bodies }\end{array}$ & 5 & 7 & 6 & \\
\hline e4.1 & $\begin{array}{l}\text { Progress in the implementation of measures, percentage of the } \\
\text { planned progress }\end{array}$ & & & 100 & 100 \\
\hline e5.1 & $\begin{array}{l}\text { Number of governance bodies having websites, percentage of the } \\
\text { total number }\end{array}$ & & & & \\
\hline $\mathrm{e} 5.2$ & $\begin{array}{l}\text { Number of declarations submitted not in person to tax authorities, } \\
\text { percentage of total number of declarations }\end{array}$ & & & & \\
\hline e5.3 & $\begin{array}{l}\text { Number of reports submitted not in person to statistics authorities, } \\
\text { percentage of total number of reports }\end{array}$ & & & & \\
\hline e5.4 & $\begin{array}{l}\text { Number of reports submitted not in person to state social insurance } \\
\text { fund, percentage of total number of reports }\end{array}$ & & & & \\
\hline e6.1 & $\begin{array}{l}\text { Adoption of legislative changes based on proposals set forth through } \\
\text { mass media }\end{array}$ & & - & - & \\
\hline e6.2 & Cases of limiting the rights of journalists & - & - & - & - \\
\hline e6.3 & Number of TV channels & - & - & - & 7 \\
\hline e6.4 & Number of newspapers & - & - & - & \\
\hline e7.1 & $\begin{array}{l}\text { Share of women in the total number of parliament deputies, } \\
\text { percentage }\end{array}$ & 4 & 5 & 7 & 7 \\
\hline $\mathrm{e} 7.2$ & Participation of women on community councils, percentage & - & 4.3 & 5.9 & 6.2 \\
\hline \multirow[t]{5}{*}{$\mathrm{e} 7.3$} & $\begin{array}{l}\text { Participation of women in the civil service system, percentage (by } \\
\text { groups of civil service positions) }\end{array}$ & & & & \\
\hline & Participation of women in the judiciary system, percentage & - & - & - & 10 \\
\hline & $\begin{array}{l}\text { Share of women in the total number of school principals, } \\
\text { percentage }\end{array}$ & - & - & - & 32 \\
\hline & $\begin{array}{l}\text { Share of women in the total number of parliament deputies, } \\
\text { percentage }\end{array}$ & & & & 56 \\
\hline & Participation of women on community councils, percentage & - & - & - & 64 \\
\hline $\mathrm{e} 7.4$ & $\begin{array}{l}\text { Participation of women in the civil service system, percentage (by } \\
\text { groups of civil service positions) }\end{array}$ & 21 & 18 & 21 & \\
\hline e7.5 & Participation of women in the judiciary system, percentage & - & - & 37.8 & \\
\hline $\mathrm{F} 1$ & Environmental Status Index & - & - & - & \\
\hline F1(i) & General Territorial Environmental Status Index & - & - & - & \\
\hline F1(i). 1 & Atmospheric Air Status indicator & - & - & - & \\
\hline F1(i). 2 & Water resources status indicator & - & - & - & \\
\hline F1(i). 3 & Land resources status indicator & - & - & - & \\
\hline F1(i). 4 & Biodiversity status indicator & - & - & - & \\
\hline F1(ii) & General Human Activity Environmental Index & - & - & - & \\
\hline F1(ii). 1 & Cleaning atmosphere from emissions indicator & - & - & - & \\
\hline F1(ii).2 & Effective use of water resources indicator & - & - & - & \\
\hline F1(ii). 3 & Solid waste management indicator & - & - & - & \\
\hline
\end{tabular}




\begin{tabular}{|c|c|c|c|c|c|}
\hline Number & Indicator & 2001 & 2002 & 2003 & 2004 \\
\hline F1(ii).4 & Effective use of energy indicator & - & - & - & \\
\hline F1(ii). 5 & Biodiversity preservation indicator & & - & - & \\
\hline F1(ii).6 & Environmental investments indicator & & - & - & \\
\hline F1(ii).7 & $\begin{array}{l}\text { Indicator for serious environmental damage caused to the } \\
\text { natural environment or any object having regional or national } \\
\text { significance (Lake Sevan) }\end{array}$ & & & & \\
\hline $\mathrm{f} 1.1^{*}$ & Emission of hazardous substances into the atmosphere, thousand ton & 151.6 & 154.7 & 175.6 & 205.1 \\
\hline fl.1(i) & $\begin{array}{l}\text { Emission of hazardous substances from stationary sources, } \\
\text { thousand ton }\end{array}$ & 17.0 & 21.4 & 28.1 & 40.7 \\
\hline f1.1(ii) & $\begin{array}{l}\text { Emission of hazardous substances from mobile sources } \\
\text { (vehicles), thousand ton }\end{array}$ & 134.6 & 133.3 & 147.5 & 164.4 \\
\hline $\mathrm{f} 2.1$ & River classification by water pollution nidex & - & - & - & \\
\hline $\mathrm{f} 2.2$ & Lake classification by water pollution index & - & - & - & \\
\hline f2.3 & Share of population having access to improved sanitary systems & & - & - & \\
\hline $\mathrm{f} 2.4$ & Share of non-treated wastewaters, percentage & 45.2 & 38.4 & 50.8 & 39.7 \\
\hline f3.1 & The altitude of Lake Sevan mirror above sea level, m & 1896.3 & 1896.8 & 1897.2 & 1897.7 \\
\hline f3.2 & Average clarity of Lake Sevan water, $\mathrm{m}$ & - & - & - & \\
\hline f3.3 & $\begin{array}{l}\text { Avergae concentration of oxygen dissolved in Lake Sevan water, } \\
\mathrm{mg} / \mathrm{l}\end{array}$ & & & - & \\
\hline $\mathrm{f} 4.1$ & Share of forest-covered areas, percentage & 11.2 & 11.2 & 11.2 & 11.2 \\
\hline f4.2 & Intensity of the use of forest resources, percentage & 13.4 & 15.3 & 16.4 & 17.1 \\
\hline f4.3 & Forest restoration, ha & 1132.0 & 840.0 & 684.0 & 2376.8 \\
\hline f5.1 & $\begin{array}{l}\text { Intensity of industrial waste production, } \mathrm{kg} / 1 \text { unit of GDP } \\
(\mathrm{kg} / \mathrm{US} \$ 100)\end{array}$ & 15.0 & 13.5 & 573.5 & 496.5 \\
\hline f5.2 & Intensity of solid municipal waste generation, $\mathrm{kg}$ per capita & & & - & \\
\hline f5.3 & $\begin{array}{l}\text { Volume of waste decontaminated (eliminated) or used as secondary } \\
\text { raw material, ton }\end{array}$ & & & & \\
\hline f5.3(i) & $\begin{array}{l}\text { Share of waste decontaminated (eliminated) or used as secondary } \\
\text { raw material, percentage }\end{array}$ & & & - & \\
\hline f6.1* & $\begin{array}{l}\text { Share of land areas subject to urgent amelioration (and/or) restoration } \\
\text { in the total area of usable lands }\end{array}$ & 20.5 & 20.5 & 20.5 & 20.5 \\
\hline f7.1 & Green areas for common use in cities of Armenia, sq. m per capita & & & & \\
\hline f8.1 & Expenditures on measures /programs & & & & \\
\hline f8.1(i) & million $A M D$ & 223 & 239 & 386 & 999 \\
\hline f8.1(ii) & percentage of $G D P$ & 0.02 & 0.02 & 0.02 & 0.05 \\
\hline f8.1(iii) & $\begin{array}{l}\text { percentage of overall revenues from environmental and } \\
\text { nature use fees }\end{array}$ & 9.8 & 7.8 & 6.9 & 28.8 \\
\hline f9.1 & Share of electricity produced from renewable sources, percentage & 14.9 & 15.0 & 15.0 & 15.2 \\
\hline f9.2 & Share of electricity produced from renewable sources, percentage & 11.4 & 23.3 & 26.9 & 24.6 \\
\hline
\end{tabular}




\section{Annex 10 PRSP revision proposals from NGO sector}

\begin{tabular}{|c|c|}
\hline Proposals & Author \\
\hline $\begin{array}{l}\text { Organize regular round tables with participation of officials representing the tax and } \\
\text { customs state institutions and the representatives of business circles. The meetings } \\
\text { should be devoted to the disclosure of specific, artificial impediments revealed through } \\
\text { the NGO sector activities and should be put on the table for further consideration. }\end{array}$ & $\begin{array}{l}\text { Environmental Issues } \\
\text { NGO Group }\end{array}$ \\
\hline $\begin{array}{l}\text { Establish a hot line, functioning adjacent to the PRSP Steering Committee, for } \\
\text { receiving a swift feedback to such cases. }\end{array}$ & $\begin{array}{l}\text { Environmental Issues } \\
\text { NGO Group }\end{array}$ \\
\hline \multicolumn{2}{|l|}{$\begin{array}{l}\text { During the PRSP update the number of urban households with gas and central heating } \\
\text { should be recorded. }\end{array}$} \\
\hline 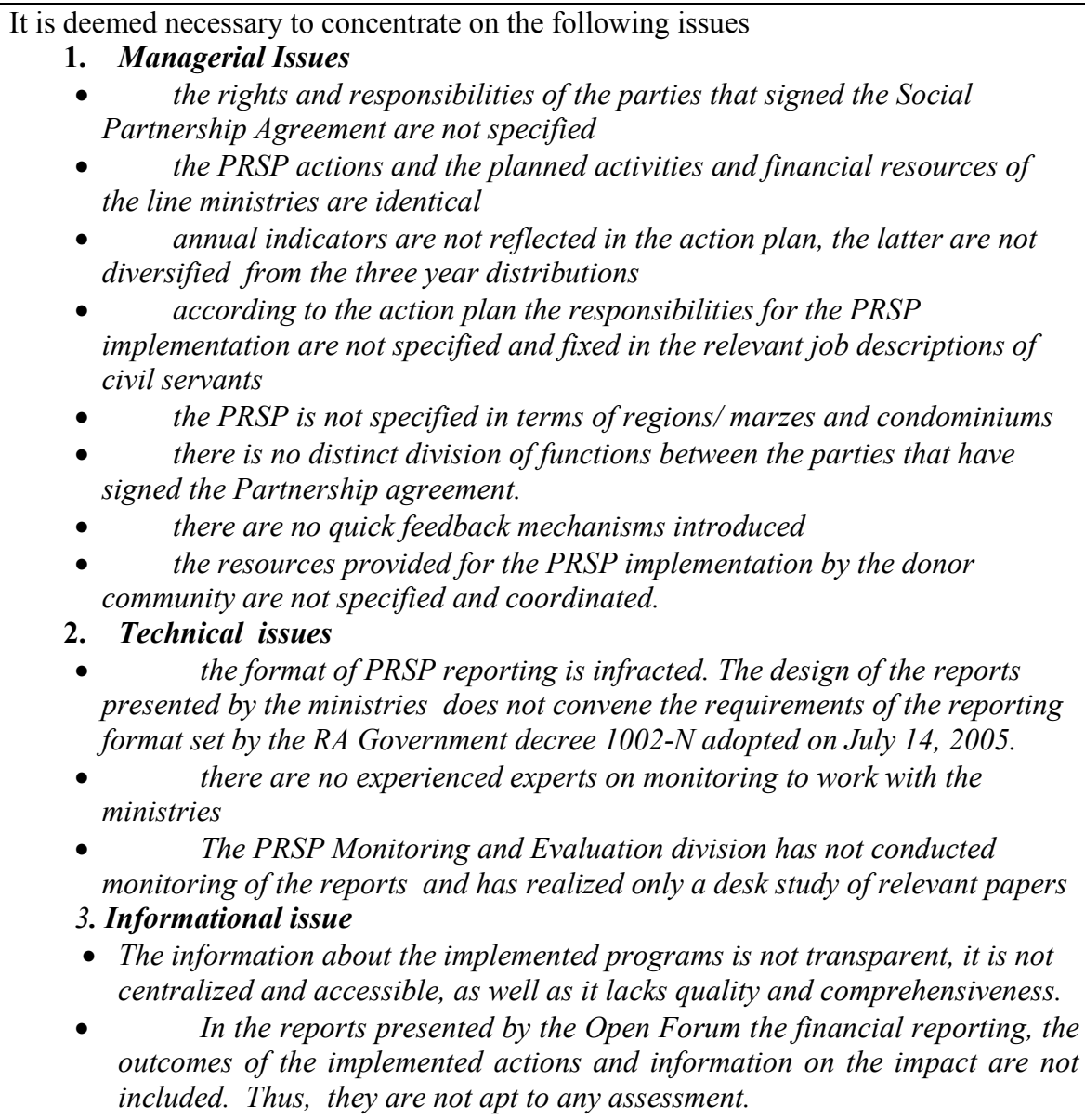 & $\begin{array}{l}\text { SME Issues NGO } \\
\text { Group } \\
\text { Human Rights } \\
\text { Protection NGO Group } \\
\text { Environmental Issues } \\
\text { NGO Group }\end{array}$ \\
\hline $\begin{array}{l}\text { The PRSP action plan, as well as the financial resources should be strictly } \\
\text { specified and diversified according to the priorities set by the RA Government action } \\
\text { plan. A precise action plan, with definite sector, regional targets including the scope } \\
\text { of responsibilities of the involved key actors, the time table and the description of } \\
\text { financial resources reporting system should be designed. }\end{array}$ & $\begin{array}{l}\text { SME Issues NGO } \\
\text { Group } \\
\text { Human Rights } \\
\text { Protection NGO Group }\end{array}$ \\
\hline $\begin{array}{l}\text { 2. Distinguish from the PRSP financial resources and provided to the NGO } \\
\text { sector the financial and technical supplies. }\end{array}$ & Environmental Issues \\
\hline $\begin{array}{l}\text { Review the Social Partnership Agreement, specify the rights and obligations } \\
\text { of the parties that have signed the agreement, ensure parity mechanisms of } \\
\text { cooperation and necessary working conditions. }\end{array}$ & NGO Group \\
\hline $\begin{array}{l}\text { 4. Engage the cicvil society representatives into the monitoring and evaluation } \\
\text { process through providing relevant financial resources. }\end{array}$ & \\
\hline $\begin{array}{l}\text { 5. Review the monitoring indicators, set evelauation mechanisms, develope and } \\
\text { apporve the methodology for the common unified system }\end{array}$ & \\
\hline Enhance the monitorng skills and capacitites of both governmantal and non- & \\
\hline
\end{tabular}




\begin{tabular}{|l}
\hline \multicolumn{2}{|c|}{ Proposals } \\
\hline governmnetal institutions \\
7. Use the Open forum web page for wide spread and coordination of \\
information concnerning the realized activites. \\
8. Create necessary possibilities especially for regional mass media to \\
highlight the PRSP implementation process and make it more transparent. \\
9. Enhance the logistical capacities of the non-governmental sector \\
representatives that have signed the Social Partnership Agreement. For efficient \\
organization of the PRSP implementation process provide a resource centre with all \\
the necessary equipment and logistics to the negotiating parties as a permanent room \\
for conducting meetings and discussions.
\end{tabular}

It is deemed necessary to concentrate on the following issues during the PRSP Update

- Divide the problems related to the entrepreneurship into two main classes. The main difficulties of financial and administrative character existing in the managerial and legislative levels are included into the first and the most essential group of problems, such as tax liabilities and confusions and drawbacks that result from the latter. The problems concerning the financial and banking system of the country as well as related to the substantial part and involvement of the Government in the economic activities are included into the first group of problems. The next class of problems involves issues such as corruption, administrative and bureaucratic obstacles that are directly connected with the daily management of the economic settings. This set of impediments can be complemented with a number of problems related to the exercise and interpretation of laws, as well as to other issues of legal character.

- $\quad$ The level of awareness about the activities of the state officials is very low. One third of the interviewees were of the opinion, that there is no information on coordination of the administrative proceedings, standards and guidelines of the decision making procedure.

- $\quad$ The cases of corruption invovle the spheres of public services, conatcts with the tax and customs officials, issues related to getting licenses.

- $\quad$ The legislation in effect and the system of regulations underlie all cases of corruption. The laws are inexplicable and ambiguous, they are formulated in a way that make a room for unclear interpretations. The laws adopted are not only unequal, but create favorable conditions for companies having dominant position in the market. A distinctly formulated laws and serious activities are necessary to combat corruption. The effectiveness of bribing, absence of control and inefficient juridical system are the biggest incentives for spread of corruption.

$78.1 \%$ of the interviewees do not grant credit to the juridical system. The reason for such low rating are the inefficient and rigid methods applied by the juridical bodies.

- $\quad$ According to the entrepreneurs the public service sector is characterized by low level of control, violation of legislative norms and regulations or by following personal interests through deception.

- The negative attitude of the entrepreneurs towards the corruption is explained by their moral values, alternative means of fighting corruption, and mainly by the negative impact that the cases of corruption have on the activities of the companies.

- There is also the opposite opinion related to the establishment of an impartial non governmental organization that would resist corruption. The task of such an organization would be to publish anonymously the registered cases of corruption and the names of corrupted officials in mass media.

- The perspectives of resisting further spread of corruption through the involvement of business associations does not yet prove to be an efficient alternative

- Even in case when they are ready to support anti-corruption initiatives the entrepreneurs rather prefer to act separately than through any business organization, provided that the confidentiality would be ensured.
SME Issues NGO Group 


\begin{tabular}{|c|c|}
\hline Proposals & Author \\
\hline $\begin{array}{l}\text { The most successful anti-corruption strategy should consist, on the one hand } \\
\text { of a timely and well coordinated activities and, on the other hand, should be } \\
\text { based on the development of alternative means of fighting corruption such as } \\
\text { establishment of anti-corruption organizations, insurance of wide publicity, } \\
\text { etc. } \\
\text { - For raising the quality of public services and reducing the cases of } \\
\text { bribing, the GOA should concentrate its capacities on simplification of } \\
\text { administrative procedures and making them faster. It should ensure provision } \\
\text { of comprehensive and precise information, organization of trainings for the } \\
\text { state officials. } \\
\text { According to the interviewees, establishment of a competent and non- } \\
\text { corrupted institute for realization of control over the cases of corruption and } \\
\text { exercising compulsory pressure mechanisms, as well as publication of } \\
\text { corruption cases and the names of officials involved in those cases are the } \\
\text { measures that the GOA should focus its attention at. } \\
\text { The clearly formulated rules guiding the course of actions of the officials and } \\
\text { regular exercise of the relevant anti-corruption laws are also viewed as } \\
\text { possible means of fighting corruption. } \\
\text { Elaboration of transparent rules on the course of acting and principles of behavior } \\
\text { for the officials, as well as "respectable attitude towards the client" can have a } \\
\text { positive impact. }\end{array}$ & \\
\hline $\begin{array}{l}\text { - Introduce systemic changes into the policy and strategy of the educational } \\
\text { sector: } \\
\text { Introduce legislative amendments into the RA Laws on "General Education" } \\
\text { "Vocational, Higher and Post Graduate Education". The current governance system } \\
\text { is based on operation of education councils cannot ensure high quality education. } \\
\text { Introduction of this reform in the educational sector is fraught with negative } \\
\text { consequences. } \\
\text { Consider general education starting from the pre-school institutions up to higher } \\
\text { education institutions as common, unified system. } \\
\text { Provide special importance to the scientific sphere } \\
\text { a) The scientific institutions serve a forge of practical knowledge for the } \\
\text { vocational, higher education, post graduate education institutions. } \\
\text { b) Scientific sphere is the basis of economic development } \\
\text { c) Interaction of science and industry, financial expenditures in the scientific } \\
\text { sphere, particularly in the sphere of technical sciences. } \\
\text { Elaborate programs for receiving additional funding for the educational } \\
\text { institutions and to apply the latter for ensuring sustainable guarantees for } \\
\text { education } \\
\text { Implement training programs for the local personnel in marzes (can prove } \\
\text { to be a more efficient use of financial resources) in stead of assigning the teachers } \\
\text { - } \\
\text { - } \\
\text { option parallel to the existing strategy } \\
\text { Change the attitude of the public towards the education } \\
\text { Ensure introduction of control mechanisms } \\
\text { Develop natural sciences } \\
\text { Introduce art and ethics into the list of main disciplines of the school } \\
\text { Conduct review of the most essential disciplines, methodologies. }\end{array}$ & $\begin{array}{l}\text { Human Rights } \\
\text { Protection NGO Group }\end{array}$ \\
\hline
\end{tabular}


Annex 11. Poverty assessment new metodology

The new methodology has the following peculiarities

- For the household consumption calculations, except the standard food and nonfood products the durables have been also taken into account.

- The differences existing between the consumption of adults and children were taken into account. If previously the consumption was estimated at per capita rate, currently it is estimated at the rate of an adults.

- The new food basket has been defined in terms of inflation.

- The stricture of the minimum food basket and its caloric content has been changed.

- Instead of the 24 nominations of products 195 are included in the structure of the of the consumption basket.

- The caloric content of the basket has changed from 2100 to 2232 kilocalories

\begin{tabular}{|l|c|c|c|c|}
\hline \multirow{2}{*}{ General line of poverty (AMD) } & \multicolumn{2}{|c|}{ Old Methodology } & \multicolumn{2}{c|}{ New Methodology } \\
\cline { 2 - 5 } & $\mathbf{1 9 9 8 / 1 9 9 9}$ & $\mathbf{2 0 0 4}$ & $\mathbf{1 9 9 8 / 1 9 9 9}$ & $\mathbf{2 0 0 4}$ \\
\hline Extreme (food) poverty line & 11735 & 14595 & 17663 & 19373 \\
\hline Poverty rate (\%) & & & & \\
\hline Extreme poverty rate (\%). & 7194 & 8954 & 11210 & 12467 \\
\hline
\end{tabular}

